بل مجلة الخدمة الاجتماعية 


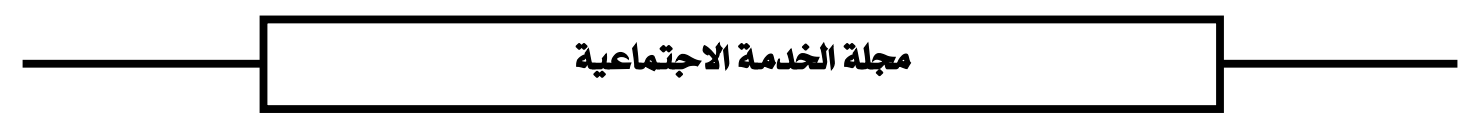

|l

يهدف البحث الحالي إلى التعريف بإستر اتيجية التثريس التبادلي والتعلم التعاوني وخرائط المفاهيم وطريقة استخدامها لتقديم الخذمة للتناميذ الذين لليهم صعوبات تعلم في القراعة في فصول التعليم العام

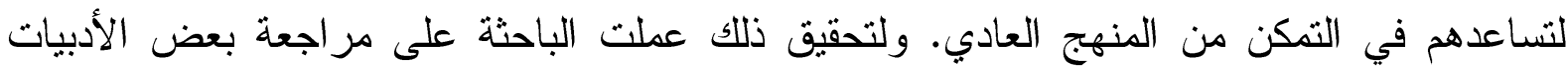

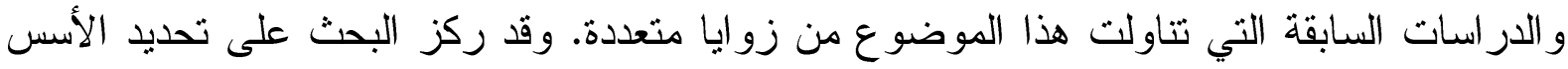
النظرية التي بنيت عليها تلك الاستراتيجيات، وأسس تطبيقها داخل الصف وفوائد تطبيقها للتلاميذ عامة وللتلاميذ الذين لديهم صعوبات تعلم خاصة. وقد توصل هذا البحث إلى أن الاستر اتيجيات

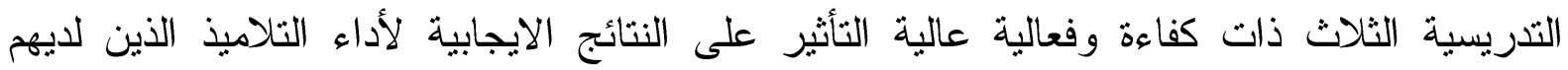

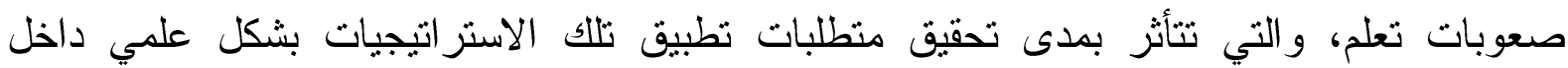

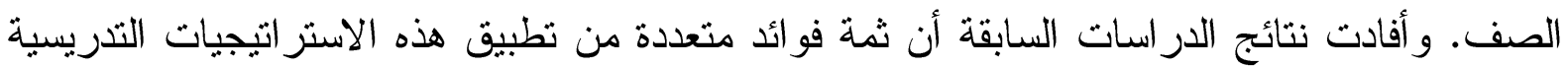
داخل الصف لتمكين التلاميذ الذين لديهم صعوبات تعلم في القراءة من التمكن من المنهج العادي، كما

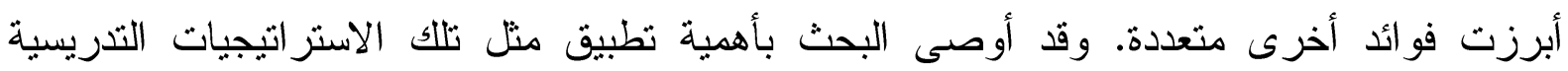
المتتوعة داخل الفصول العادية من قبل معلم الصف لجميع التلاميذ، وإجراء المزيد من البحوث، وتعديل المناهج لتتضمن هذه الاستراتجيات و إعداد المعلمين الأكفاء لتطبيقها داخل الصف ولف بماء بكفل للتلاميذ الذين لديهم صعوبات تعلم فرص منكافئة. 


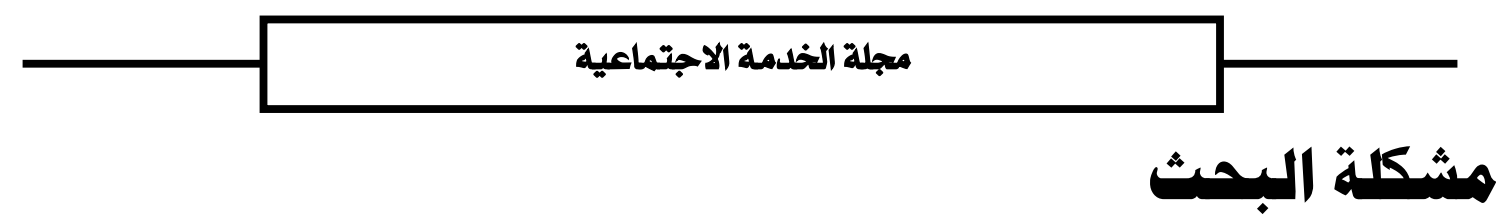

لا شك أن بيئة الصف العادي هي البيئة الطبيعة و المكان التربوي الأفضل للتلميذات اللاتي لديهن صعوبات تعلم في القراءة، وان المنهج العادي هو منهجه كذللك، ولكن الاختلاف يكمن في كيفية توصيل مفردات ومهار ات هذا المنهج إلى كافة تلميذات الصف على اختلاف قدر اتهم واحتباجاتهم وأساليب التعلم لديهر.

وبعد الممارسة الفعلية من قبل الباحثة، لمهنة التدريس في مدارس المرحلة الابتدائية داخل الصفوف العادية وداخل غرفة المصادر، واجهت مشكلة حقيقية وهي عدم انسجام التلميذات اللاتي

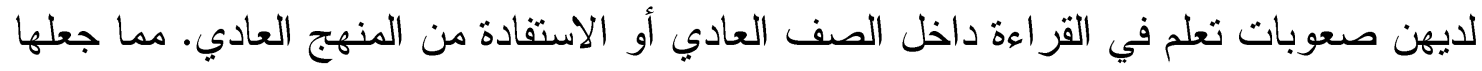
تلتمس حاجة التلميذات اللاتي لايهن صعوبات تعلم في القراءة لاستر اتيجيات تدريس حديثة مناسبة لاحتباجاتهن الفردية، داخل الصف.

و انطلاقاً من خبرة الباحثة كذلك في الإشر اف على معلمات صعوبات تعلم لاحظت فارق مستوى التلميذات اللاتي لايهن صعوبات تعلم في القراءة بين غرفة المصادر وبين الصف العادي. حيث ينخفض مستو اهن بالصف العادي نتيجة للتركيز على استخدام الاستر اتيجيات التقليدية في التدريس، مما دفعها إلى القيام بهذه البحث، الذي تأمل من ورائه الكثف عن استر اتيجيات تدريس

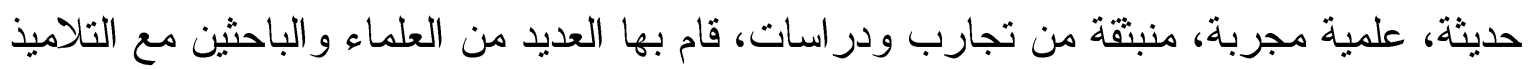

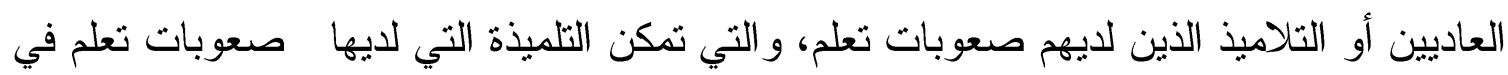

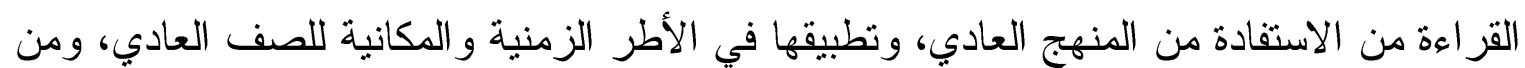

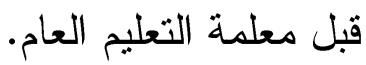

وميدان التنريس مليء بالإستر اتيجيات الحديثة، المتتوعة و المختلفة التي تستخدم مع تلاميذ الصف العادي. ولكن السؤال هنا هل استر اتيجيات التنريس الحديثة التالية: التعلم التعاوني و التثريس

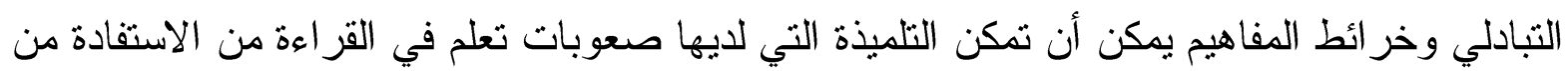
الدنهج العادي داخل الصف؟ هذا ما يحاول البحث الحالي الإجابة عليه. وبالتالي يوفر دليلاً إرشادياً يمكن المعلم من الاستفادة من تلك الاستر اتيجيات وتطبيقها داخل الصف. ويجعل من العملية التعليمية داخل الصفوف الدر اسية عملية ديناميكية مفيدة. 

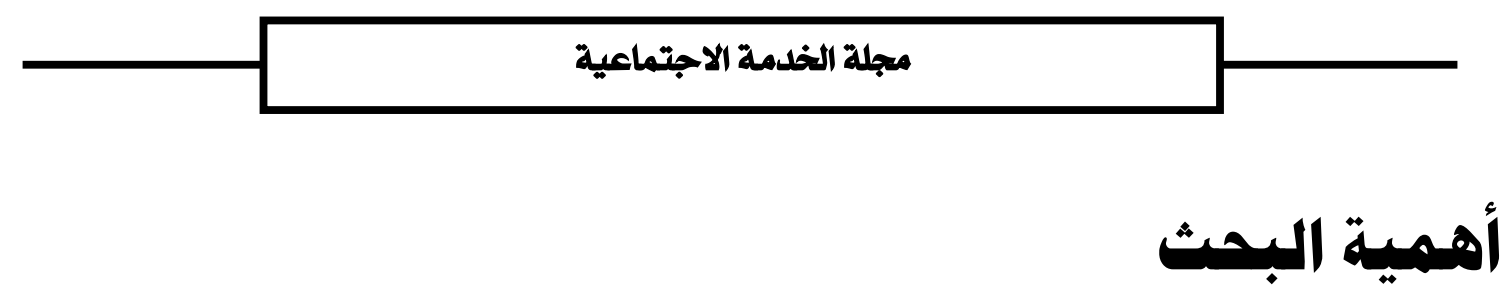

يعتبر التعليم حقاً من حقوق الإنسان التي تخول لكل فرد الحق أن يحصل عل تعليم مجاني مناسب لخصائصه وقدر اته، وان يتم هذا التعليم في بيئة قليلة القيود بما يتلاءم مع الاحتياجات التعليمبة الفردية لكل فرد بصرف النظر عن قدراته واحتياجاته، لذلك برزت الحاجة الملحة إلى ضرورة تكييف الفصل و المنهج واستحدث استر اتيجيات تقوم فلسفتها على فرضية أساسية أن جميع التلامبذ يمكن مساعدتهم على تطوير مهار اتهم وقدر اتهم والاستفادة من المنهج الحالي بكل ما يحويه من كتب ووسائل ومفاهيم ومعلومات.

ومن هذا المنطلق لا بد من البحث عن استراتيجيات و أساليب جديدة تر اعي الفروق الفردية وتو اكب العصر الحديث.حيث يشير عبدالحليم (2009) إلى أن طريقة التدريس مهمة كالمنهج نفسه و هي العامل الثاني في حصول التعلم الحق، فالمنهج مهما كان غنياً لا يمكن أن يفيد إلا إذا تضمن طريقة تدريس تستطيع أن تؤثر بالمنهج في شخصية التلميذ، أي تستطيع حقيقة أن تمكنه من تعلمه.

ويمثل البحث الحالي جانبا نظريا، لجهود وبحوث كثير من الباحثين و المفكرين و الخبـر اء فـي إيجاد استر اتيجيات مختلفة ومتتو عة ومجربة، تمكن التلاميذ الذين لديهر صعوبات تعلم من الاســتفادة من المنهج العادي داخل الصف.باستخدام استر اتيجيات مختلفة ومتتوعة.مما يكفل حق التلميذ الذي لديه صعوبات تعلم في القراءة في البيئة الأقل قيودا ، في إطار من الكيفية و الزمنية المناسبة لقدراتـهـو تتبع أهمية البحث من أهمية الموضوع الذي تتناوله وهو تدريس التلاميذ الذين لديهم صعوبات تعلم في القر اءة، وذلك لأهمية تلك الفئة في المدارس وحاجتهم إلى استر اتيجيات تدريس حديثة. و إلقاء الضو ء على استر اتيجيات تدريس ذوي صعوبات التعلم.

\section{هنف البمثث}

يهرف البحث الحالي إلى التعرف على مدى فاعلية التعلم التعاوني، التذريس التبادلي، خر ائط المفاهيم في تمكين التلميذات اللاتي لديهن صعوبات تعلم في القر اءة من الاستفادة من المنهج العادي داخل الصف. 


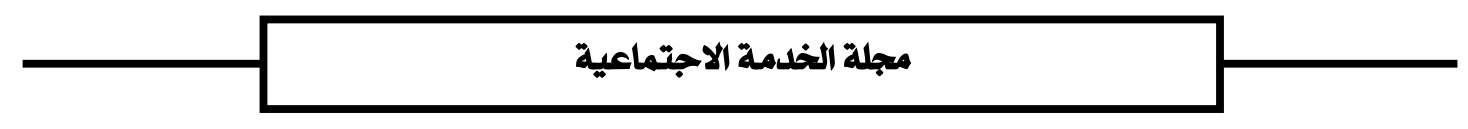

\section{أسـألة البحث}

يحاول هذه البحث الإجابة على الأسئلة التالية:

ا. ما مدى فاعلية إستر اتيجيات التدريس عامة في تمكين التلميذة ذات صعوبات التعلم في القراءة

من الاستفادة من المنهج العادي؟

r. ما مدى فاعلية إستر اتيجية التدريس التبادلي في تمكين التلميذة ذات صعوبات التعلم في القراءة

من الاستفادة من المنهج العادي؟

ك. ما ددى فاعلية إستر اتيجية التعلم التعاوني في تمكين التلميذة ذات صعوبات التعلم في القـــراءة من الاستفادة من المنهج العادي؟

ع. ما مدى فاعلية إستر اتيجية خر ائط المفاهيم في تمكين التلميذة ذات صعوبات التعلم في القراءة من الاستفادة من المنهج العادي؟

\section{وثمات البمات}

نظر أ لتعدد الرؤى حول تعريفات مصطلحات البحث فقد أخذت الباحثة بالتعريفات الآتية:

ا ـ استر اتيجيات التدريس:

مجموعة الأفعال والأداء و الأنشطة التي يقوم بها المعلم بقصد جعل التلاميذ يحققو أهدافاً تعليمية

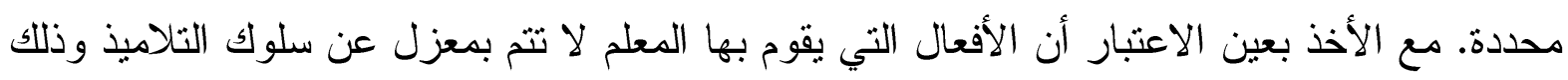

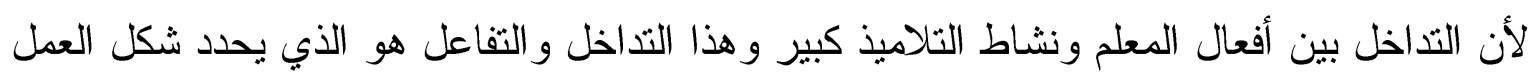
التعليم (يحي و المنوفي، 1991 (191).

وتم التطرق في هذه البحث لثلاث نماذج من الاستر اتيجيات التدريسية وهي: 


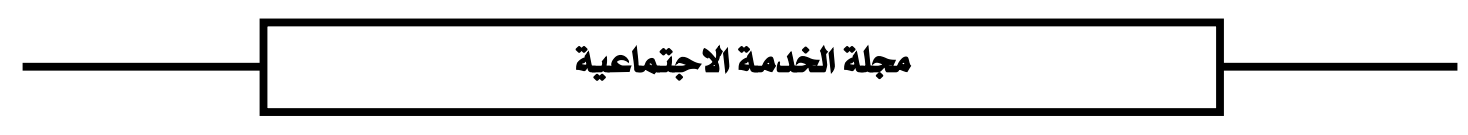

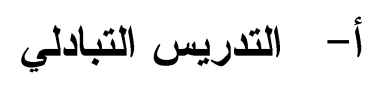

"إجر اءات تفاعلية على هيئة حوار بين التلاميذ والمعلم أو التلاميذ بعضهم بعضيًا يتبادلون فيه

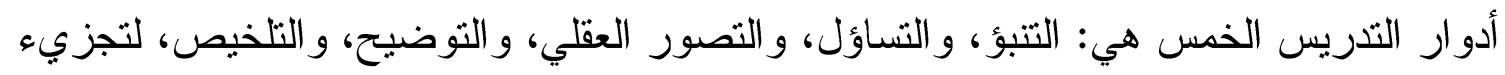

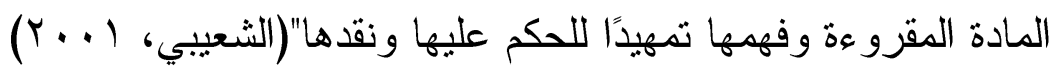

\section{ب- - - 1التعلم التعاوني}

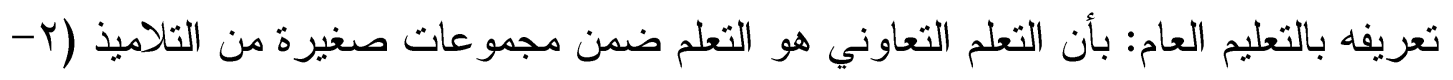

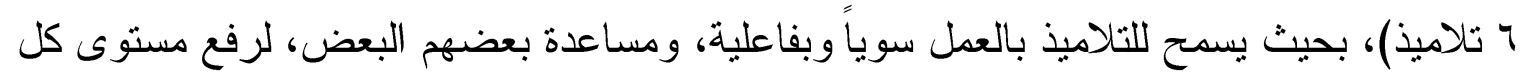
فرد منهم وتحقيق الهدف التعليمي المشترك. ويقوم أداء التلاميذ من خلال مقارنته بمحكات معدة مسبقاً

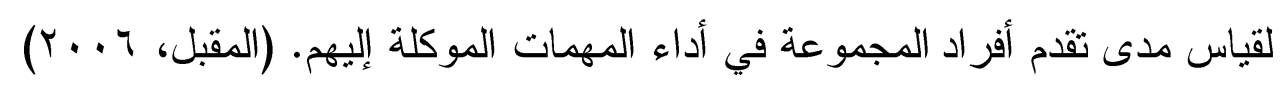

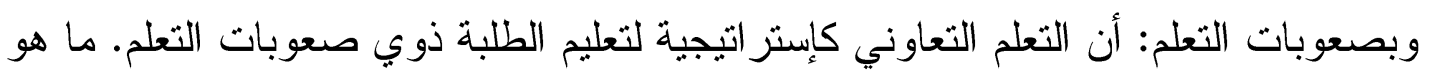

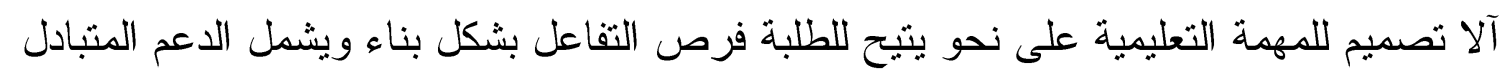

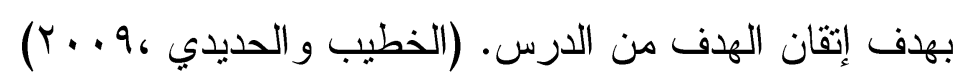

\section{ت- ت خرائط المفاهيم}

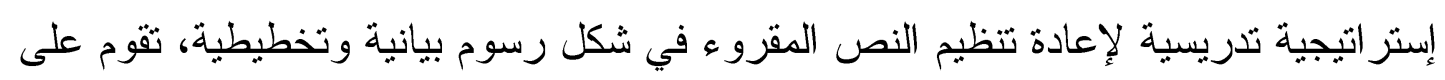

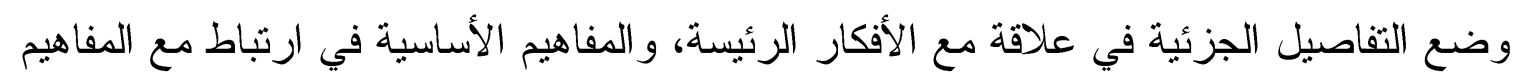

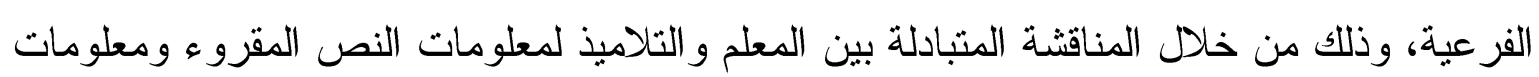

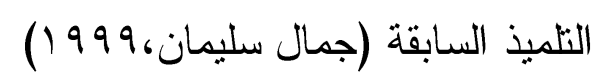

r. تمكين:

التمكين لغة: إعطاء ما يصح به الفعل كائنا ما كان من الآلات و العدد و القوى. (ابن منظور،

وتزى الباحثة أن التمكين بالمفهوم الثامل العام يعني:

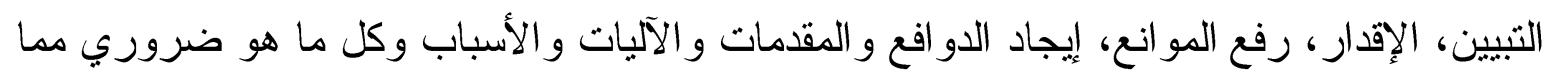
لا يصح الفعل إلا معه، ولا يحصل الفعل إلا معله. 


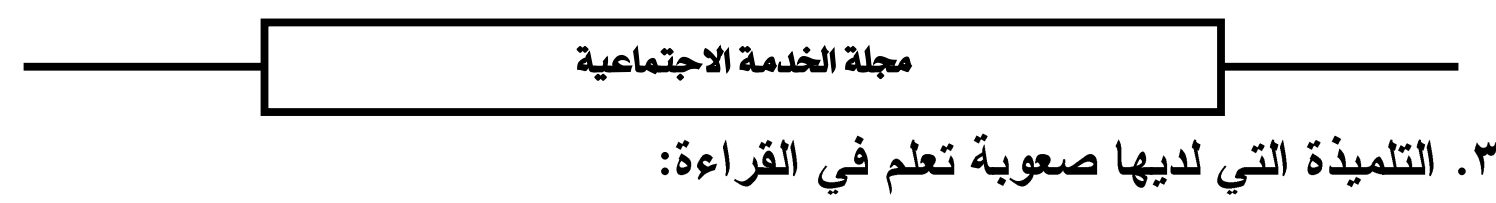

التلميذة التي لديها صعوبات تعلم في القز اءة هي التي ينخفض مستوى أدائها في القر اءة سواء

الجهرية أو الصامتة عن مستوى تحصيلها المتوقعة بناء على قدر اتها العقلية ومقارنة بقريناتها

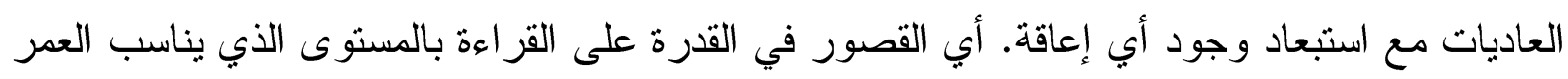

الزمني مع العمر العقلي للتلميذة، رغم إتاحة الفرصة للتعلم مقارنة بالقرينات. (السيد، و ج . . ب).

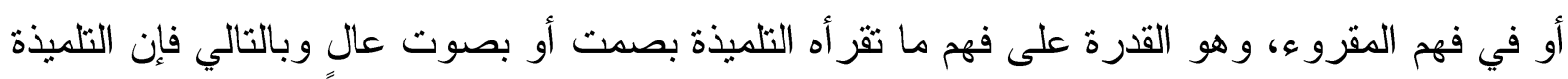

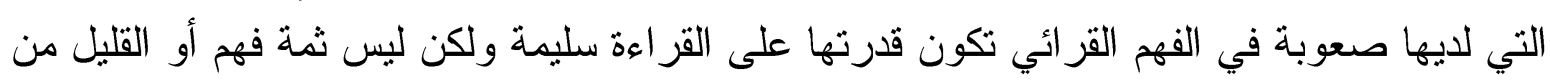
الفهم لما تتم قر اءته" (الصاوي، 9 . . بـم).

انطلاقاً من طبيعة موضوع الدر اسة و المتمثل في استر اتيجيات تدريسية لتمكين التلميذة التي لديها

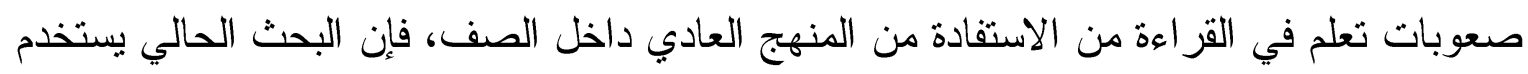

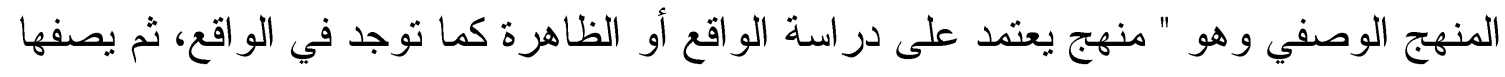

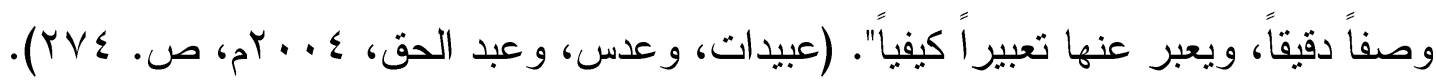

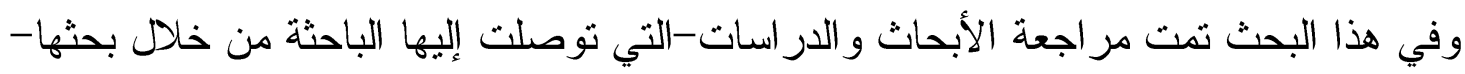

و التي تتاولت فاعلية الاستر اتيجيات التدريسية عامة على التلاميذ الذين لديهم صعوبات التعلم في القر اءة، وفاعلية استر اتيجية التدريس التبادلي و إستراتيجية التعلم التعاوني وإستر اتيجية خر ائط المفاهيم

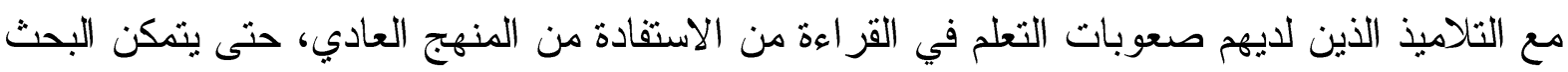

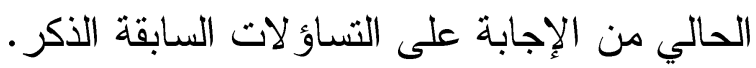
تم العمل على مر اجعة عدد من الأدبيات و الدراسات السابقة المرتبطة فاعلية الاستر اتيجيات

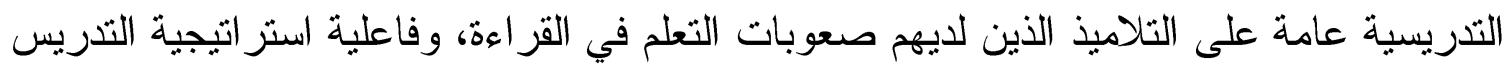

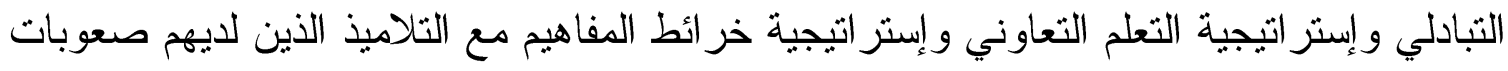

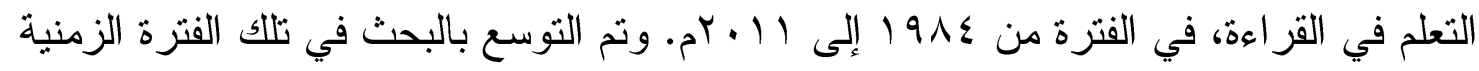

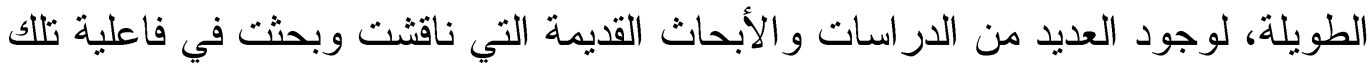

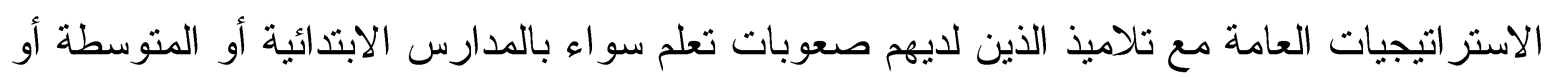
الثانوية وحتى بالعيادات، وفيما يلي معايير الدراسات السابقة التي تمت مناقثتها و استعر اضها: 


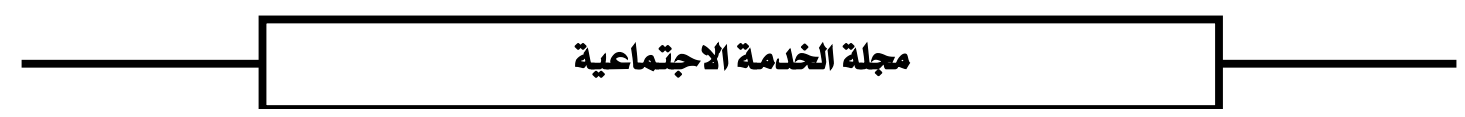

1- تم حصر البحث في ثلاثثن در اسة للمحاور الأربعة مجتمعة، منها بr در اسة مزودة بتفاصيل العينة، و ^ فقط ذكرت أهم النتائج النهائية. وكانت اغلب تللك الدراسات تجريبية ميدانية، لاختبار الفاعلية و التأثير لتلك الاستر اتيجيات.

r- تتاولت الدر اسات السابقة فاعلية الاستر اتيجيات التدريسية عامة على التلاميذ الذين لديهم صعوبات التعلم في القر اعة، وفاعلية إستر اتيجية التدريس التبادلي و إستر اتيجية التعلم التعاوني و إستر اتيجية خر ائط المفاهيم مع التلاميذ الذين لديهم صعوبات التعلم في القراءة كل على حده.

ب- عينات الدر اسات هم التلاميذ الذين لديهم صعوبات تعلم عامة وخاصة في القر اءة، يدرسون في المر احل الدر اسية الابتدائية و المتوسطة والثانوية، وقد اشترك بعضهم بشكل تطوعي و البعض الآخر تم اختياره ، في فصل التعليم العام ومن ضمنهم التلاميذ ذوي الاحتياجات التربوية الخاصة و الذين

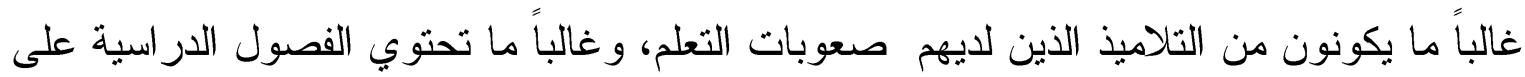
أعداد تلاميذ بين ( 11 - . ب تلميذ) منهم (ع- 9) تلاميذ ذوي احتياجات ثربوية خاصة.

ع- شمل البحث VI دراسة عالمية و • 1 در اسات عربية واثتتين خليجيتين وو احدة محلية.

\section{أولا: التلاميذ الذين لايهم صعوبات تعلم في القراهة}

\section{التلاميذ الأين لايهم صعوبات تعلم في القزاعة:}

تظهر صعوبات التعلم في القر اعة على أشكال متتوعة، فمن بين التلاميذ من بجد صعوبة بالغة في الوعي بالأصو ات اللغوية وفي الربط بين شكل الحرف وصوته، وفي تكوين كلمات من مجموعة من الحروف وفي التمبيز بين الحروف التي قد تختلف اختلافات بسيطة في شكلها. هذا ويظهر بين التلاميذ من يجد صعوبة في التعرف السريع على الكلمات وفي تحليل أو تهجي الكلمات الغريبة لغرض نطقها .

أما حذف بعض الحروف و إضافة البعض الآخر، أو إبدال بعض الحروف ببعض، أو تشويه نطقها، فمن الخصائص التي قد تظهر على قر اءة عدد من التلاميذ؛ كما قد يعكس بعضهم الحروف أو يقلبها مع أن هذا يبدو نادراً جداً وخاصة بعد الصف الثالث الابتدائي. هذا ويجد بعض التلاميذ الذين لديهم صعوبات القر اءة بسرعة وسهولة أمراً شاقاً فيظهر عليهح التكلف في القراءة حتى ولو تعلم التلاميذ المهار ات الأولية كفك الرموز الكتابية. فإن المرونة في القراعة تبقى مشكلة كبيرة لعدد من التلاميذ 


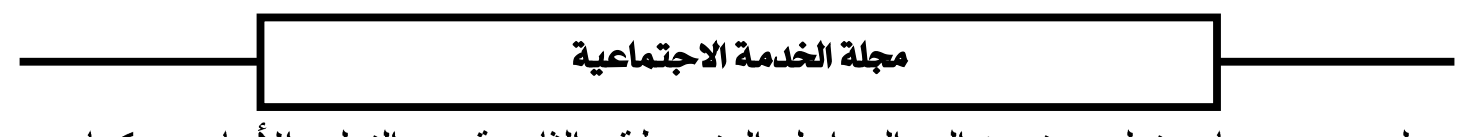

الذين لديهر صعوبات تعلم مستمرة إلى المراحل المتوسطة و الثانوية من التعليم الأساسي. كما يجد

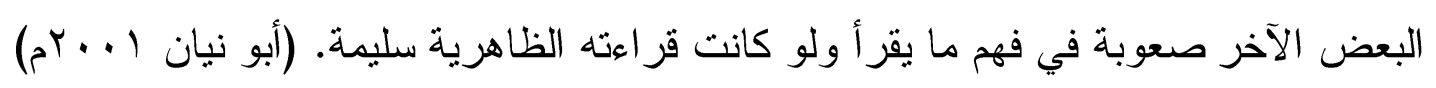

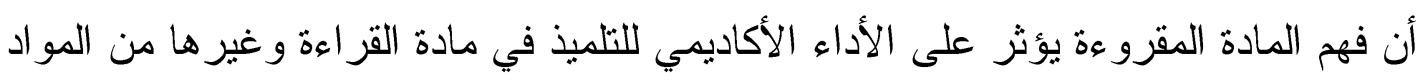

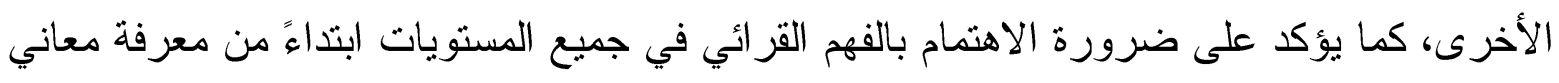

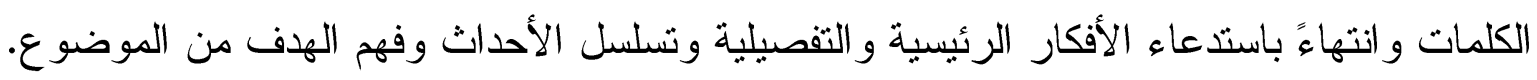

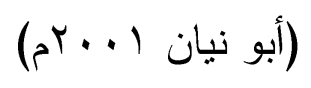

هذا وأن المكونات المعرفية للفهم القرائي تتضمن التالي:

$$
\text { فهز فهر معاني الكلمات. }
$$

ت تنظيم المادة المقرو عة.

سر عة الفهر.

$$
\text { مستوى الفهم القرائي المعرفي العام. }
$$

وبالنسبة لتلاميذ ذوي صعوبات التعلم غالباً مايكون أدائهم منخفض على هذه المكونات انخفاضاً

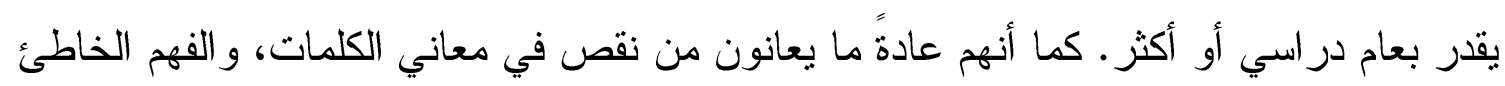

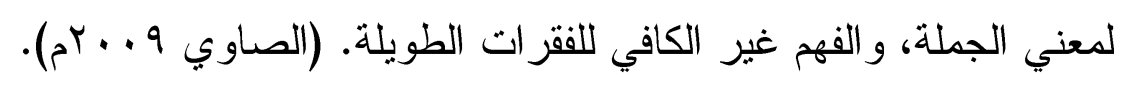

ويمكن تلخيص أسباب ضعف الإدر الك و الفهم القر ائي لدى التلاميذ ذوي صعوبات التعلم كالتالي:

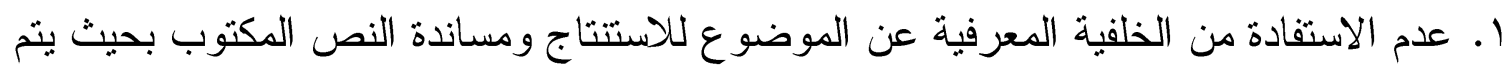
الربط بين النوعين من المعلومات. r. تغطية الخلفية السابقة على التعلم الجديد. r. الصعوبة في التعرف على الكلمات. ع. ضعف أو عدم استخدام القدرات الفوق معرفية. ه. ضعف مفهوم القر اعة لدى التلميذ فتجده يركز على القراءة الصحيحة والسريعة دون أن يعير انتباهاً للمعني.

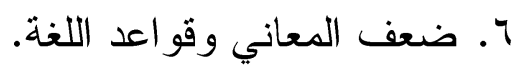

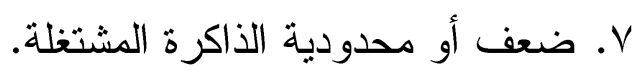

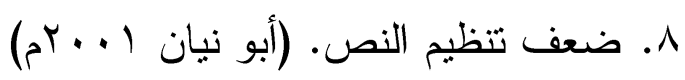




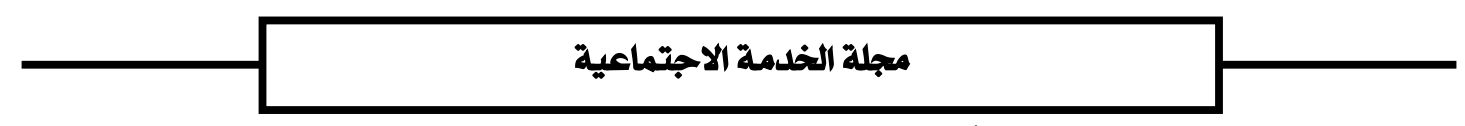

في ضوء ما تمّ تحديده حول أهمية اللغة منمثلة بالقر اعة فقد تضاعف العبء الملقى على عاتق المدرسة في تعليمهما للتلاميذ و إثارة دافعيتهم لتعلمها، وبات استحداث استر اتيجيات تدريسية، أمرا ضروريّا لتنمية الاتجاهات الإيجابيّة نحو تعلم القراءة والكتابة بالصورة الصحيحة، وتتمية مهار اتهم الأساسية، ولذلك فلا نغالي إذا قلنا إنّ تعلم القر اعة، وتكوين الاتجاهات الإيجابيّة نحوهما من أهمّ ما يشغل بال المدرسة الحديثة، لأنها أساس كلّ تعلم، وأهمّ وسيلة لاكتساب الثقافة و المعرفة. ويمكن تقديم الخدمة لمعظم التلاميذ الذين لديهم صعوبات تعلم في حجرات الدر اسة العادية في المدارس الابتدائية. و هذا ما يعرف بالوضع في "الاتجاه السائد mainstreaming " أو "التضمين inclusin".

\section{ثانيا: الاسثر اتيجياث التدريسية}

\section{ما المقصود باستر اتيجيات التدريس}

استر اتيجيات التذريس هي وسائل للتفكير و التحليل يستخدمها المعلمون لتسهل على المتعلم استيعاب و إتمام المهمة التعليمية، وتعتبر استر اتيجيات التدريس خطط توضع لتحقيق أهداف معينة،

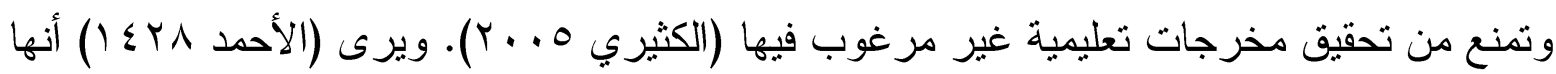
تعمح في صورة خطو ات إجر ائية، ويوضع لكل خطوة من الخطوات الإسنر اتيجية بدائل تسمح بالمرونة عند تتفبذ الإستر اتيجية، وتتحول كل خطوة من الخطوات الإستر اتيجية إلى تكتيكات، أي إلى أساليب إجر ائية تتم بتتابع مقصود ومخطط في سبيل تحقيق الأهداف المحددة.

كما أن (السايح، ا · . Y) يرى أن مفهوم إستر اتيجية التدريس يعني استخدام الوسائل لتحقيق الأهداف فالإستر اتيجية عبارة عن إطار موجه لأساليب العمل ودليل مرشد لحركته. ويمكن الإشارة إلى مفهوم إستر اتيجية التذريس على أنها " مجموعة القو اعد العامة أو الخطوط العريضة التي تعنى مونى بوسائل تحقيق هدف ما أو هي ترجمة فعلية لمسار ات علمية وخطوط عمل و اقعية المستوى الفكري أو بعبارة أخرى أنها الوجه العملي أو المرحلة الثانية الأكثر و اقعية في السياسة التعليمية

\section{مكونات إستر اتيجية التدريس:}

مكونات إستر اتيجية التدريس عديدة ومتتو عة، وتختلف باختلاف المادة التعليمية المقصودة ويرى

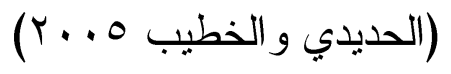

ا. عبارة عن إطار عمل مخطط لمجموعة من الأفعال و الحركات و الممارسات والإجراءات و الأساليب و الوسائل المتتابعة. 


\section{مجلة الخدمة الاجتماعية}

r. تتضمن الإستر اتيجية الأهداف التثريسية، وتتظم الدرس، و إثارة و اقعية المنعلم وتحديد الأنشطة

التعليمية.

r. تتضمن الأنشطة المنظمة التي يقوم بها المعلم أثناء التنريس و إدارة التلاميذ.

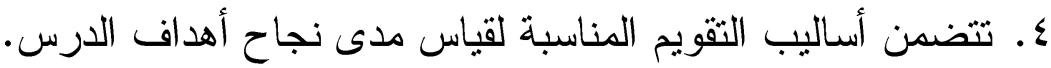
0. تتسيق النواحي المتصلة بكل ذلك بما فيها التجهيزات المكانية و الزمن.

أنواع استر اتيجيات التدريس:

ومن خلال عدة مشاهدات على ارض الو اقع وداخل الفصول الدراسية، يمكن من و اقع خبرة

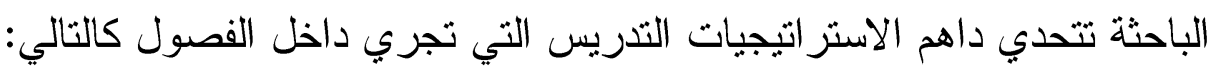

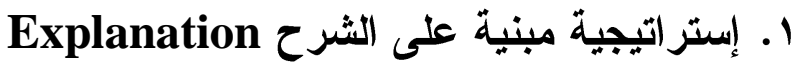
يعتمد فيها المعلم على شرحه للمعرفة وتلقينها للمتعلمين. r. إستر اتيجية مبنية على الاستكثاف Discovery يعتمد فيها المعلم على اكتثاف المتعلمين للمعرفة بأنفسهم. r. إستراتيجية التدريس المباشر Direct teaching strategies تعتمد على تعليم المعرفة أو المهارة على شكل تلقي مباشر من المعلم أو من مصادر المعرفة الأخرى ثم يتم تدريب المتعلمين عليها حتى يحفظها.

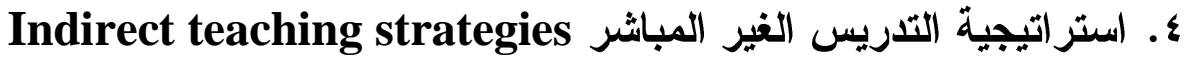
تعتمد على تعلم التلاميذ المعرفة والمهار ات من خلال ممارستهم لأنشطة التعلم الذاتي.

ه. إستر اتيجية التدريس المتمركزة حول دور المعلم Teacher centered

يكون دور المعلم فيها الأساسي فو الموجه و المرشد للعملية التدريسية من بدايتها حتى نهايتها.

آ. استراتيجيات التدريس غير المتمركزة حول المعلم Non-teacher centered يكون دور المتعلم فيها فعال، فهو يملك زمام الاختيار، فهو يختار ما يتعلمه بالطريقة والأسلوب الذي ير اه

Vask kind استر اتيجيات التّريس التي تعتمد على نوع المهمة

نركز على كيفية استخدام المتعلمين لكافة أنواع الأدبيات ومصادر المعرفة المتوفرة لديهم من اجل التعليم بطريقة أكثر فاعلية.

Aind eye استراتيجيات التدريس تعتمد على استخدام الخيال والتصور، 


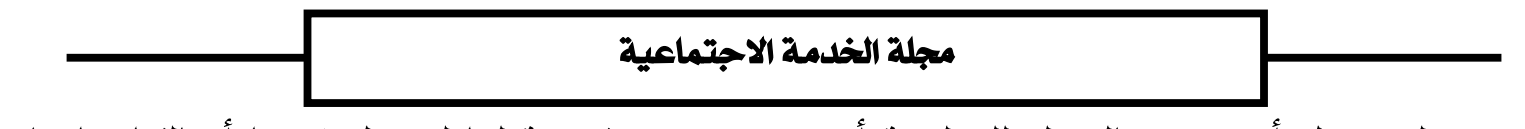

تعتمد على تخيل أو تصور المتعلم للمعلومة أو رسم صورة تقريبية لها لتسهيل فهمها أو القيام بادوار تمثيلية بحيث يستطيع تعلم المهار ات في مو اقف جديدة.

كما ترى الباحثة انه بمكن تعريفها على أنها " عملية تفاعل متبادل بين المعلم و المتعلم و المادة

الدر اسية و التي تعتبر مادة الوصل بين المعلم و المتعلم"، وأن تقسيم استر اتيجيات التدريس إلى لى له

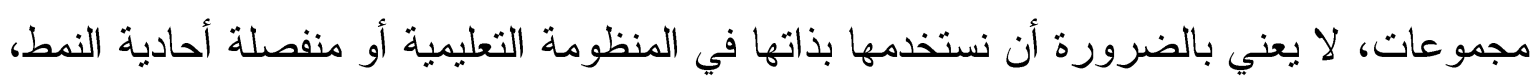
إنما على ارض الواقع، لا يمكن أن تتم كثير من المهمات التعليمبة دون استخدام العديد من الاستر اتيجيات في وقت واحد أو متتابعة. ولكن ما أن تقدم تلك الاستر اتيجيات بشكل منفصل فلن تؤدي لتي الغرض منها. ولكن من الممكن أن تقدم هذه الاستر اتيجيات كل و احدة منفصلة أثناء الشرح و إعطاء أمثلة تطبيقية لكل واحدة أمكن للتلمبذ القدرة على استيعابها وتطبيقها والقدرة على نقل المهار ات المتعلمة من خلالها إلى مهام أخرى في المو اقف الأدائية المتشابهة. 


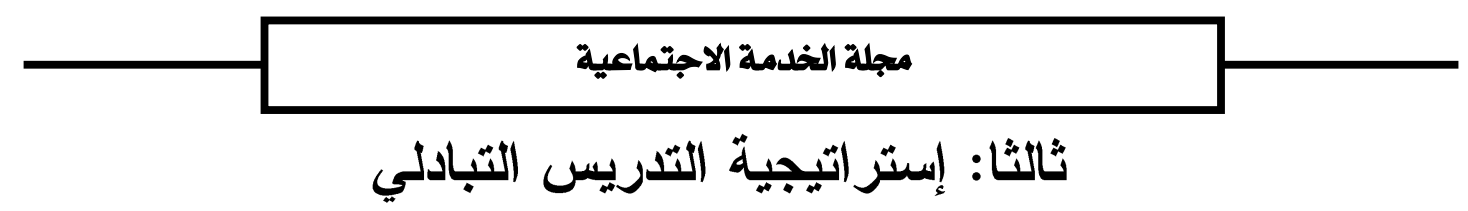

\section{إستر اتيجية التدريس الأولى التى}

ا ا الإطار النظري لإستر اتيجية التدريس التبادلي:

إن أساليب تعديل السلوك المعرفي مستمدة من النظريات السلوكية و المعرفية ونظرية التعلم

الاجتماعي، ففي إستر اتيجية التدريس التبادلي يقوم التعلم عن طريق مشاهدة الآخرين و التفاعل بين

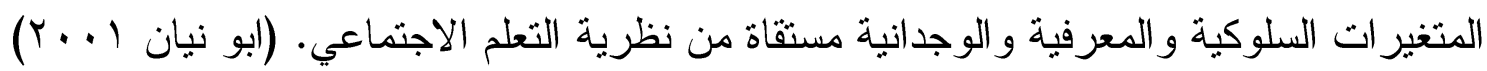

تقوم استر اتيجية التدريس التبادلي على نظرية ليف فيجوتسكي Lev Semyonovich

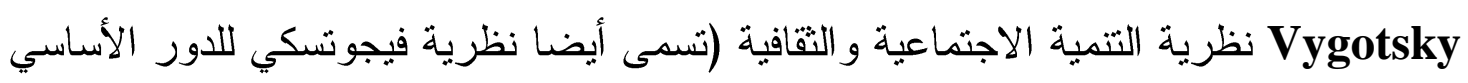

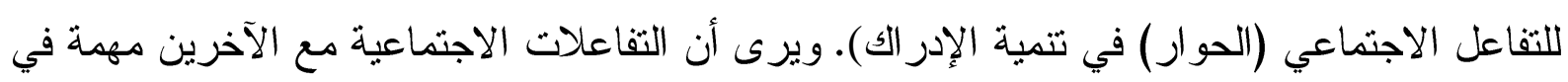

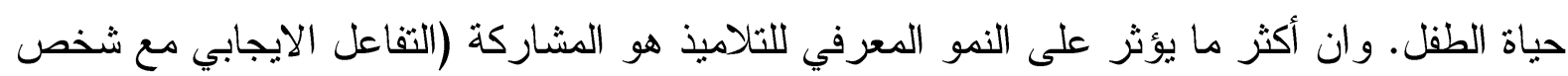

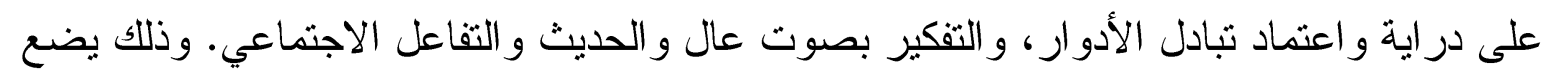

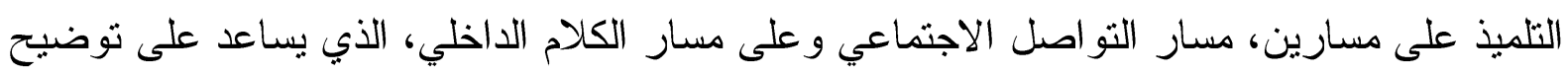

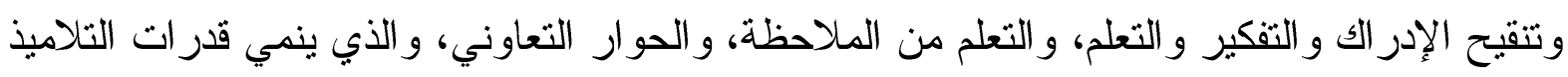

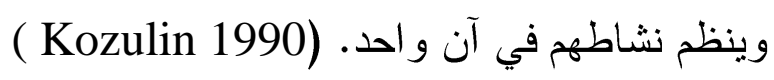

التطبيقات التربوية لنظرية فيجوتسكي في مجال صعوبات التعلم:

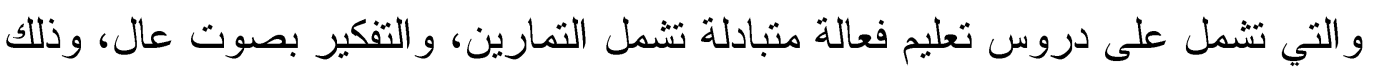

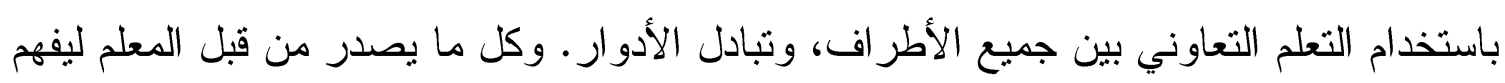

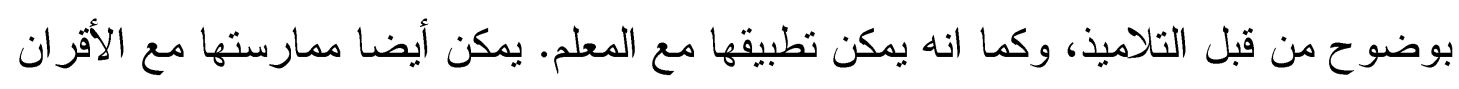

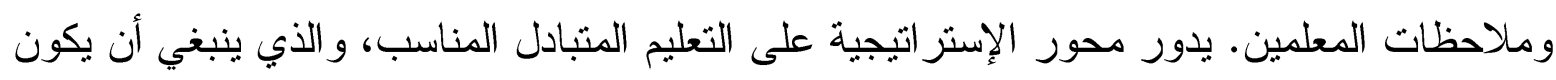

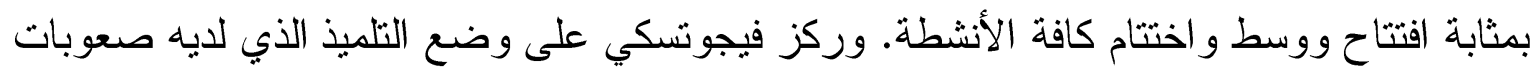
تعلم في نفس المجموعة العمرية المماتلة (الأقران) أثناء التعليم، فإن يتفاعل بايجابية مع الآخرين.

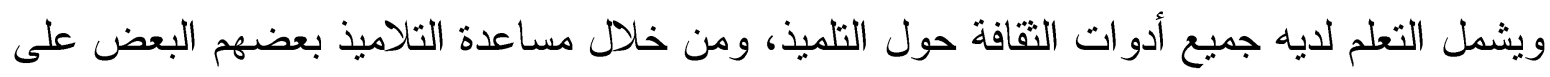

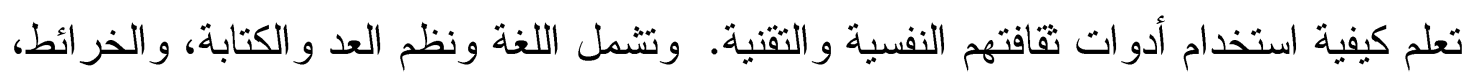

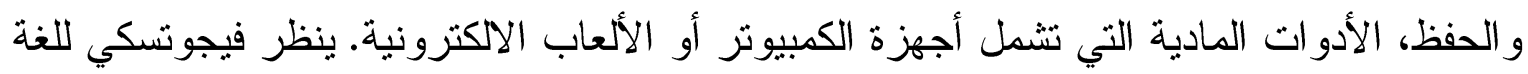

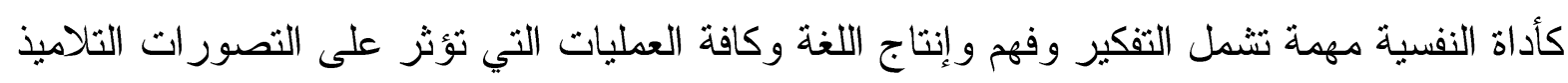
لعو المهم الاجتماعية أخير اركزت النظرية على الناحية الاجتماعية و الثقافية للتلاميذ. ( Kozulin ) 


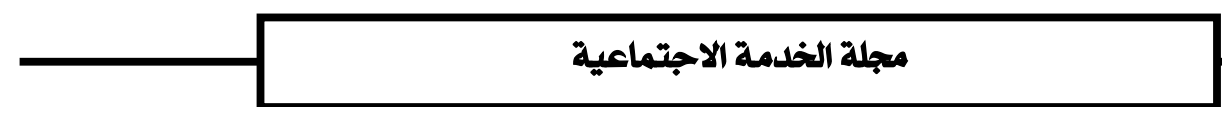

بدأت من بالينسار ، وبراون عام (ع/9 (م)) من خلال تطوير استر اتيجية التّريس التبادلي، لتساعد

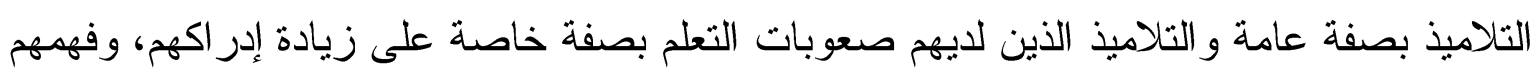

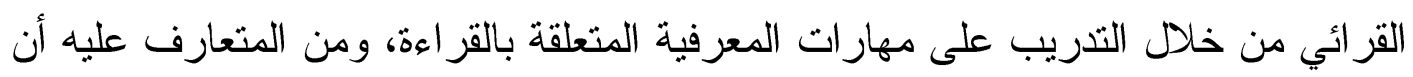

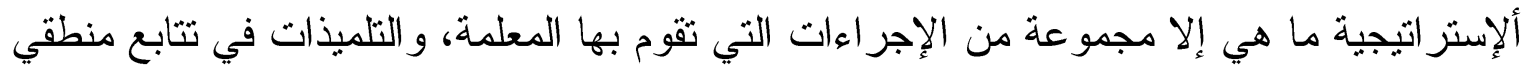

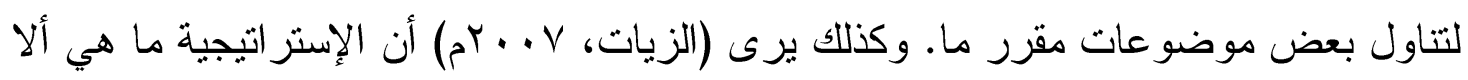
تخطيط، ومعالجة عقلية معرفية مهارية فاعلة لتحقيق الأهداف.

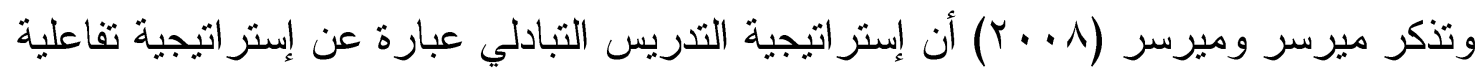
ترقى بكل من فهم النص، ومر اقبة الفهم من خلال مشاركة فاعلة للمناقشات الخاصة بالنص القر ائي. ويعمل المدرس مع التلاميذ معاً لفهم النص من خلال حوار مكون من فئ أربع استر اتيجيات هي (التتبؤ،

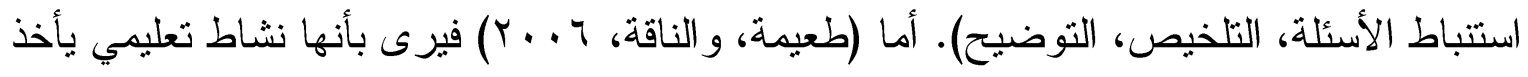

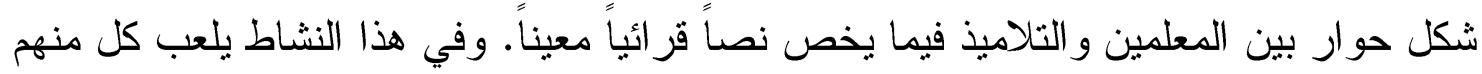
(التلاميذ و المعلمون) دوره على افتر اض قيادة المعلم للمناقثة.

\section{أهية إستر اتيجية التدريس التبادلي في مجال تعليم صعوبات التعلم خصوصا:}

إن الكثير من التلاميذ الذين لديهم صعوبات التعلم ماز الوا يتلقون التعليم باستخدام الطرق التقليدية

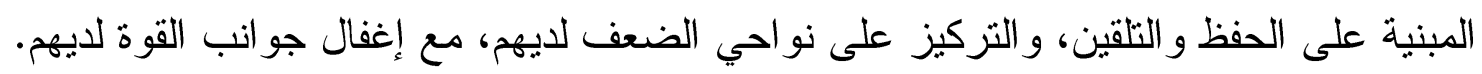

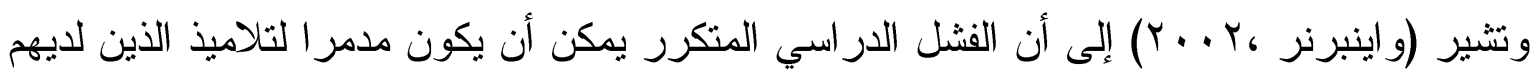

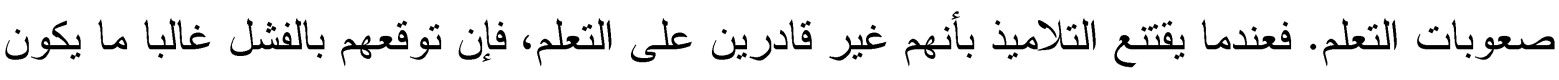

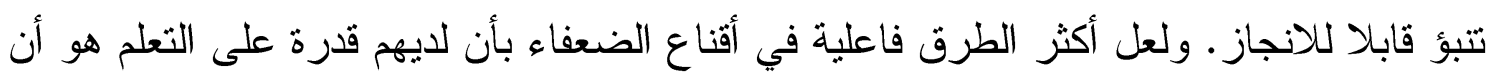
نريهم نقاط القوة لديهم.

ولذلك نجد أن التطبيقات التربوية لذوي صعوبات التعلم تعتمد على كل من: المعلم من جهة،

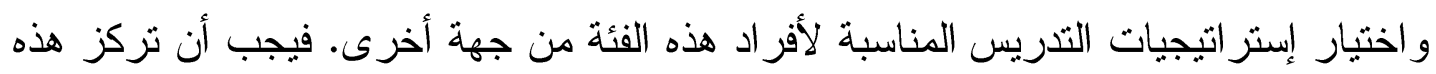

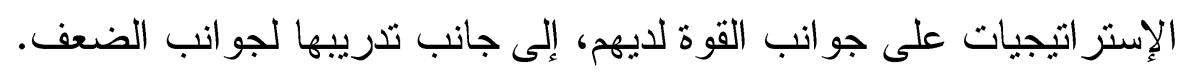

ويرى عبد الباري (• ( • rم) إلى أن غالبية الأبحاث التي تتاولت فاعلية إستر اتيجية التدريس التبادلي مع التلاميذ الذين لديهم صعوبات تعلم، توصلت إلى أن صعوبات الاستيعاب و الإدر الك أن لم الم

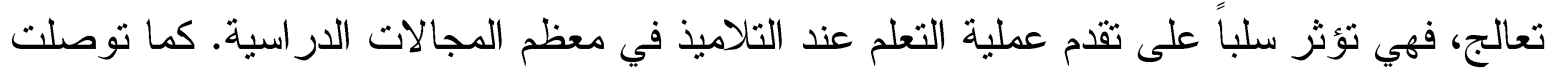

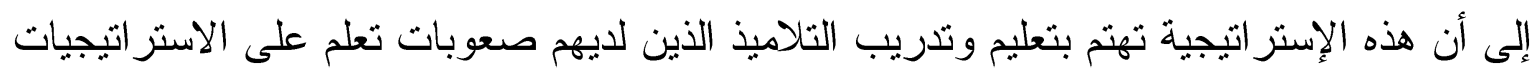

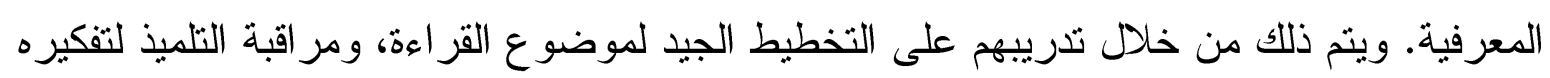




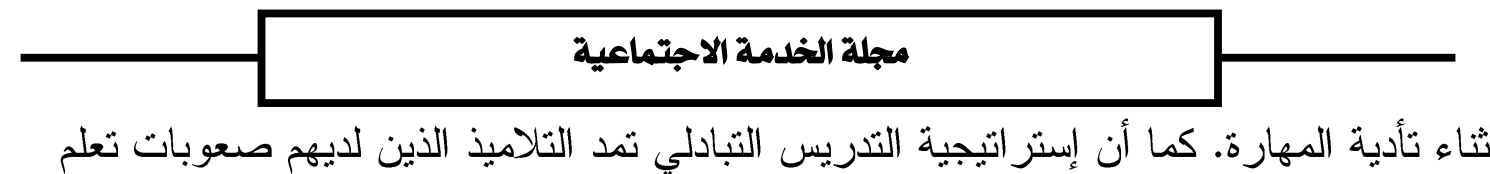

بالمساندة و الدعم أثناء مر احل التعلم، الذي من خلاله يتم تزويدهم بما بساند تعلمهم في بيئة تعليمية تفاعلية، وتعامل اجتماعي، ونقاش علمي يدور كله حول المضمون المراد تعلمه. و التلاميذ الذين لديهم صعوبات تعلم كثير اً ما يفتقون لدعم و المساندة أثناء عملية التعليم، فعندما توفر لهم إستر اتيجية التذريس التبادلي ذلك فهذا دليل كافي بحد ذاته على مدى فاعليتها ومناسبتها لهح.

تأتي أهمية إستر اتيجية التذريس التبادلي في نظر الباحثة لأنها تساعد التلاميذ الذين لايهم صعوبات تعلم على مناقشة المادة الدر اسية بالتعاون مع زملاتئه في ظل مساندة معلمهر. كما تجعلهم قادرين على مجار اة غير هم، مما يؤدي في نهاية الأمر إلى تحسن أدائهم الأكاديمي والاجتماعي على مئى وجه السواء.

\section{بيئات إستر اتيجية التدريس التبادلي:}

يذكر عبد الباري (• ( •rم) أن هناك العديد من المجالات التي تستخدم فيها إستراتيجية التدريس التبادلي سواءزاد عدد التلاميذ أو قل ومنها الحالات الآتية:

$$
\begin{aligned}
& \text { ا ـ التدريس للمجمو عة كاملة. } \\
& \text { r. التدريس لمجمو عات صغيرة. } \\
& \text { r. التدريس لطالب طالب. } \\
& \text { ع. التدريس لمجمو عات صغيرة يقودها الرفاق. }
\end{aligned}
$$

وتعتبر استر اتيجية التدريس التبادلي مفيدة مع جميع التلاميذ إلا أنها تعود بالنفع وبشكل كبير مع التلامبذ الذين لديهم صعوبات تعلم وخاصة التلميذ الذي يتعلم لغة أجنبية. كما تقبد مع التلميذ الذي ليع لا يجيد القر اعة لكنه يجيد الاستماع، و التلميذ العادي الذي يجيد المهار ات اللغوية المختلفة، إذ يساعده هذا النوع من التدريس على فهم أعمق للنص. 


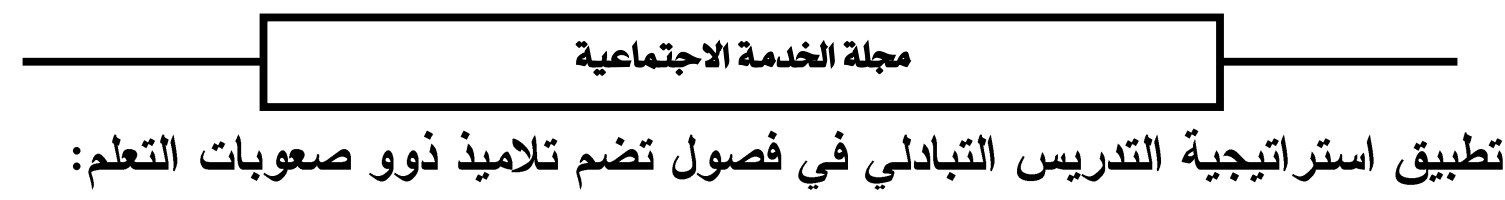

يشير طعيمه (T . T) إلى أن هناك عدد من المر احل و الخطوات التي يجب على المعلم أتباعها لتطبيق إستر اتيجية التدريس التبادلي داخل الفصل الدراسي بفاعلية مع التلاميذ بشكل عام، و الذين الذين

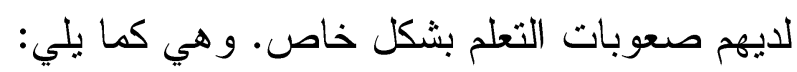

1. المرحلة الأولى (مرحلة طريقة عرض المعلم) وفيها يقوم المعلم بنمذجة الإستر اتيجية التي سيقوم بها التلاميذ فيما بعد. و المعلم في هذه المرحلة يكون لديه قدر من المعرفة و المهارة

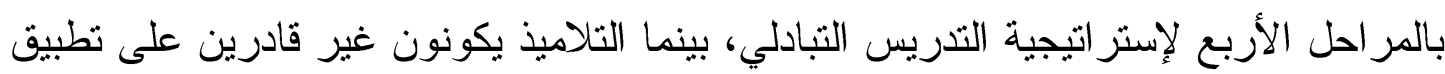
هذه الإستر اتيجيات المعرفية. r. المرحلة الثانية (مرحلة تعليم التلاميذ وتدريبهم) وفي هذه المرحلة يستمر دور المعلم كدور

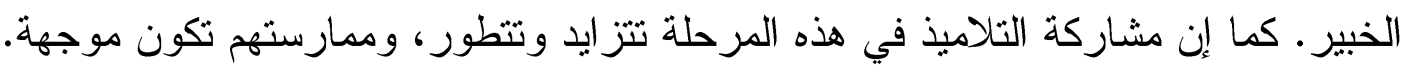
r. المرحلة الثالثة (مرحلة العلاقة بين المعلم ومجموعات التلاميذ) و هنا سيكون تركيز المعلم على المجموعات الصغيرة، كما يتم تشجيع التلاميذ ليكون لهم دور فعال أكثر من ذي قبل فيل. وفي هذه المرحلة يأخذ التلاميذ دور القيادة، كما يقبل التلاميذ تحمل مسئولية تكوين الأسئلة، ومر اجعة استخدام المر احل السابقة، ويكون دور المعلم تقديم الدعم و المساندة فقط.

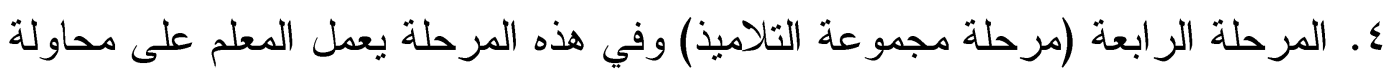

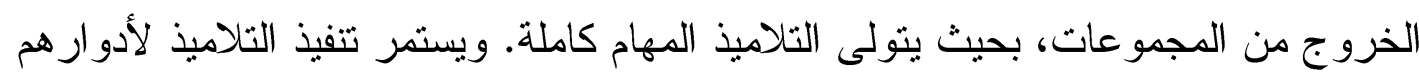
في الخطوة السابقة، مع أخذ الدعم المتدرج في التضاؤل من زملائهم.

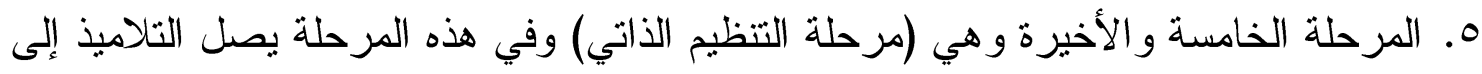

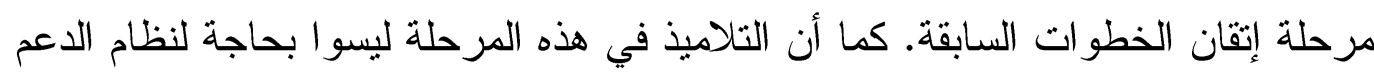
المتدرج في التضاؤل المقدم لهم من المعلم.

\section{مبادئ إستراتيجية التدريس التبادلي في الصف:}

لا شك أن كل إستر اتيجية من استر اتيجيات التعلم و التعليم تقوم وترتكز على عدد من المبادئ التي لا يمكن بدونها أتمام الإستر اتيجية. و عند الحديث عن إستر اتيجية التدريس التبادلي في تعليم

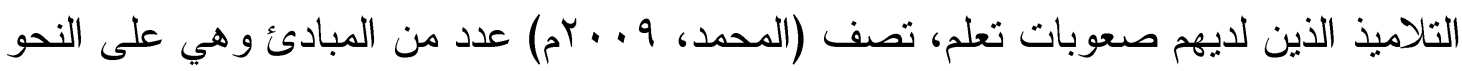




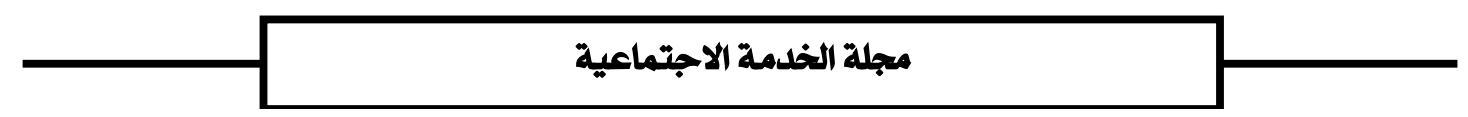

1. مبدأ النمذجة بو اسطة المعلم ويعني هنا أن يقدم المعلم مثلا للعمليات العقلية المتضمنة

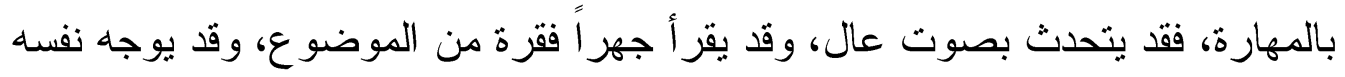

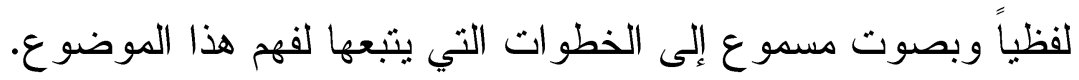

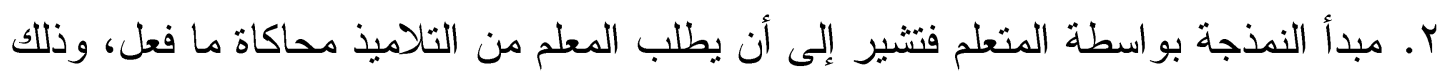

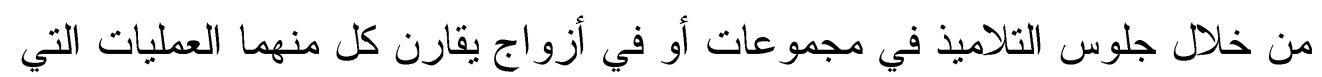

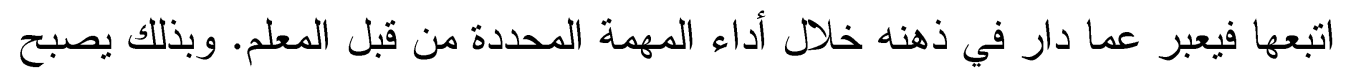

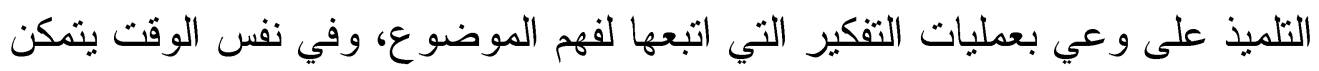
المعلم من تقييم العمليات التي اتبعها كل طالب في أداء المهارة.

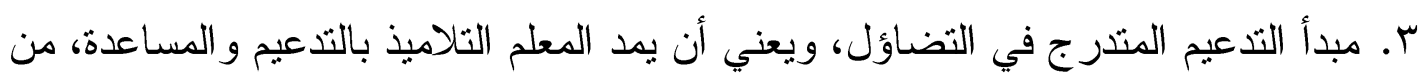

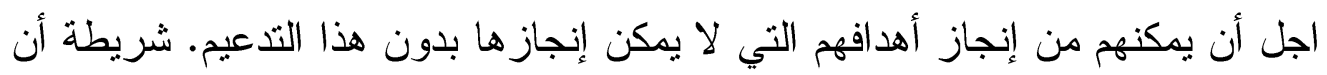

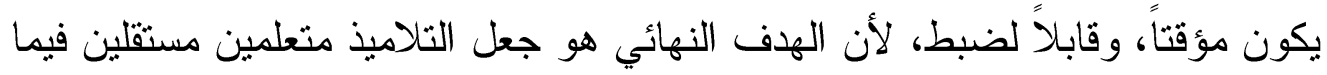

ع. مبدأ تشجيع المعلم لتلاميذه على المشاركة في المناقثات.

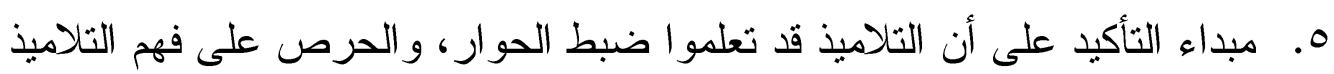
للنصوص القرائية آذ تعتبر مسئولية مشتركة بين المعلم والتلميذ.

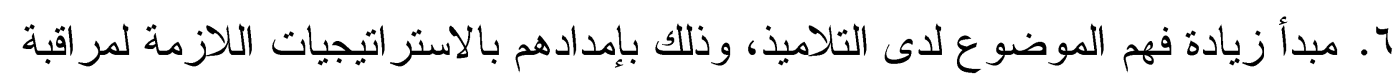

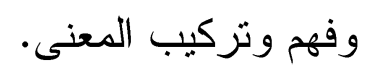

V. مبدأ إيجاد معلمين وتثلاميذ مشاركين في مسئولية التعلم الاستر اتيجي مع الانتقال التدريجي

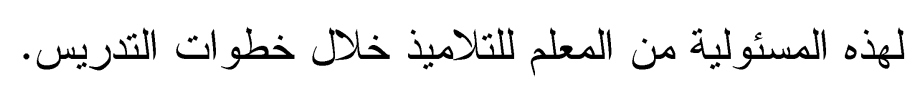

\section{ايجابيات إستر اتيجية التدريس التبادلي:}

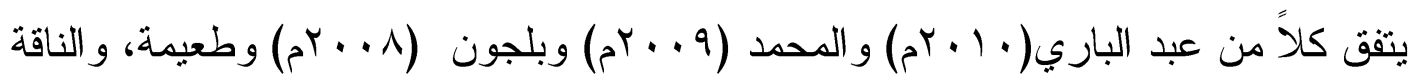
(T + . rم) إلى أن هناك العديد من الآثار التربوية التي تعود بالنفع على التلاميذ بشكل عام عند تطبيق

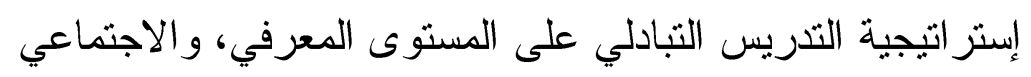

أ- المستوى المعرفي تتمثل أهم الآثار فيما يلي: ا ـ تتمية القدرة على الحوار و المناقشة لاى التلاميذ. r. ت بتمية المهار ات القيادية عند التلاميذ وتطويرها. r. تتمية قدرة التلاميذ على الفهم، وزيادة تحصيل التلاميذ في كافة المو اد الدراسية. ع. أنها تساعد التلاميذ في التغلب على الصعوبات القرائية لايهر. 


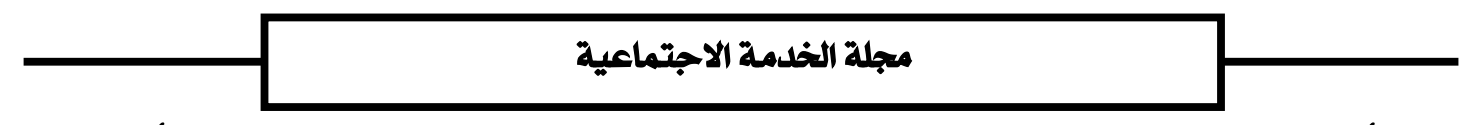

0. أنها تحمل كل تلميذ مسئولية تعلمه، وتتشيط الخلفية المعرفية له، وكذلكك ربط الأفكار الجديدة بما يمتلكه التلميذ سابقاً.

7. يكتسب التلاميذ من خلالها المعلومات المناسبة، ونماذج التفكير الجديدة.

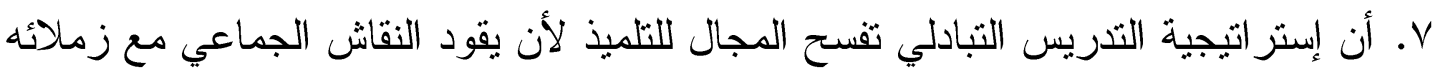
كفريق من أجل إثراء النص ذاته عند مستوى معرفي معين يتتاسب مع إدر الك التلاميذ.

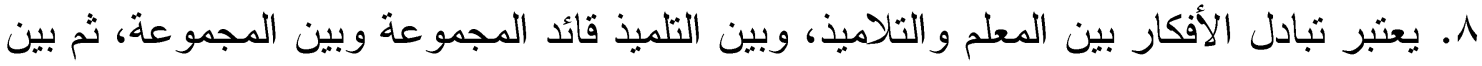
أفر اد المجموعة بعضهم البعض هو محور إستر اتيجية التدريس التبادلي.

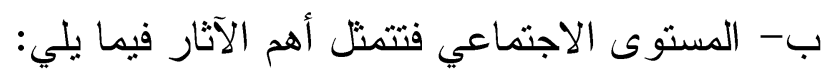
ا. تتمية روح التعاون و العمل الجماعي بين التلاميذ، وتحمل المسئولية، والاستقلال الذاتي.

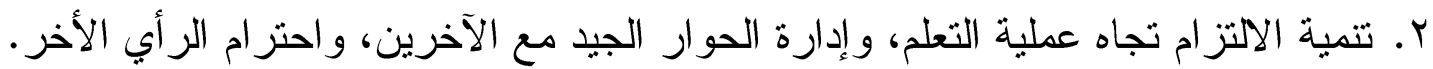
r. تشجع على مشاركة التلاميذ الخجولين في أنشطة التدريس التبادلي، وزيادة ثقة التلميذ بنفسه.

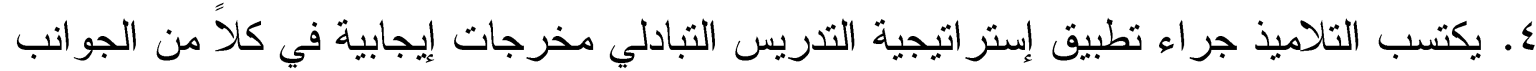
التالية (الدافعية، و العلاقات الاجتماعية، و المهار ات التعاونية، التعلم التعاوني) 


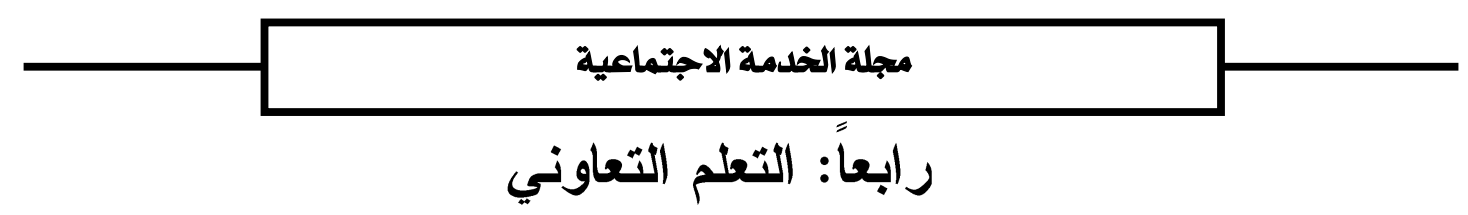

\section{الإستر اتيجية التدريسية الثانية}

الإطار النظري لإستراتيجية إستراتيجية التعلم التعاوني:

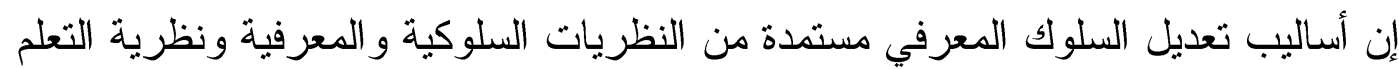
الاجتماعي، ففي إستر اتيجية التعلم التعاوني يقوم التعلم عن طريق مشاهدة الآخرين و التفاعل بين

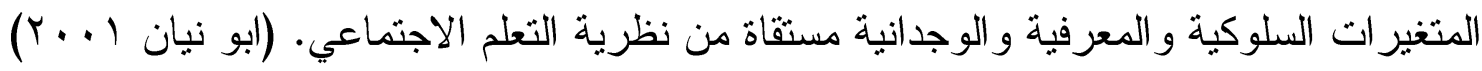

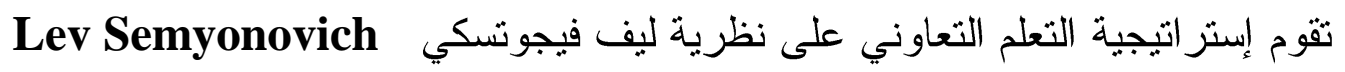
Vygotsky

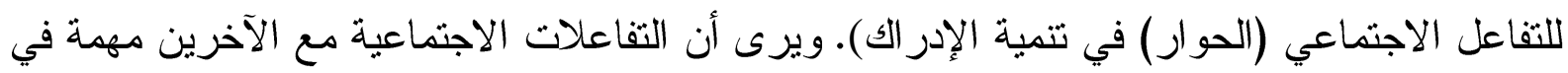

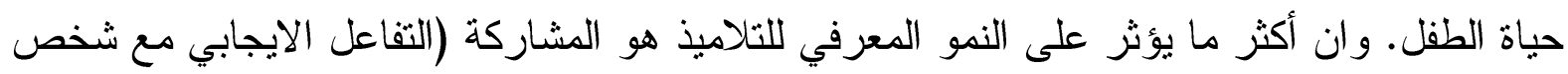

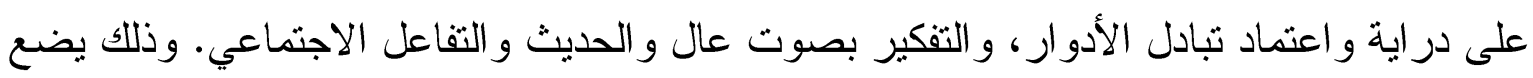
التلميذ على مسارين، مسار التواصل الاجتماعي وعلى مسار الكلام الداخلي، الذي يساعد على توضيح

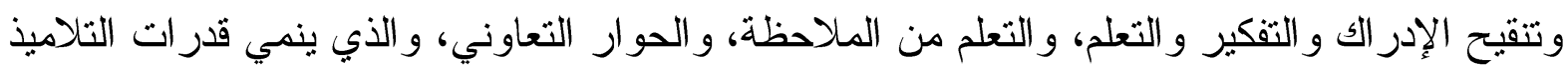

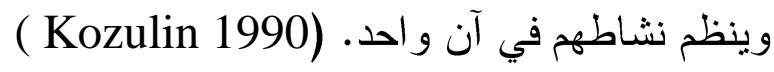
التطبيقات التربوية لنظرية فيجوتسكي في مجال صعوبات التعلم:

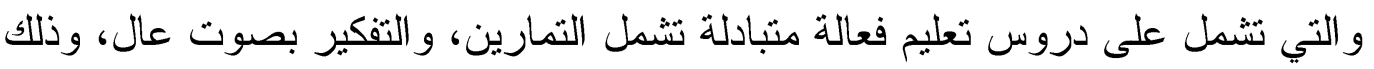

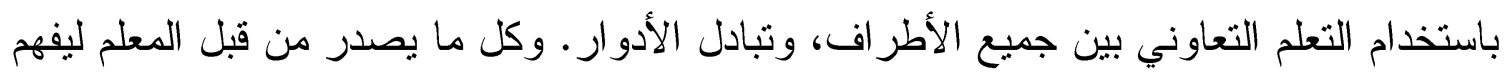

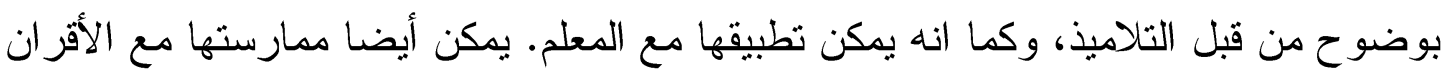

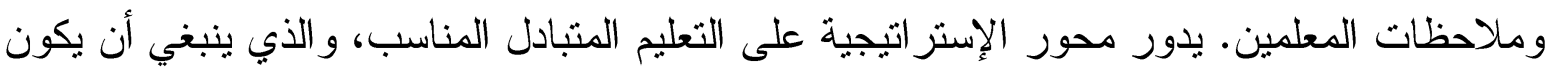

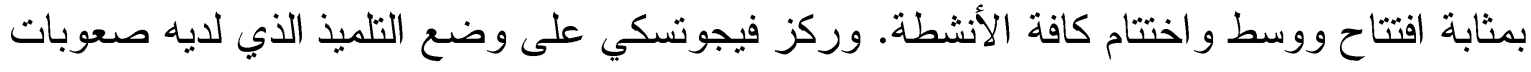

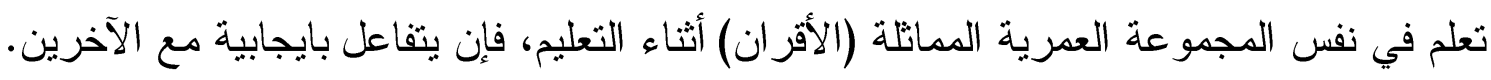

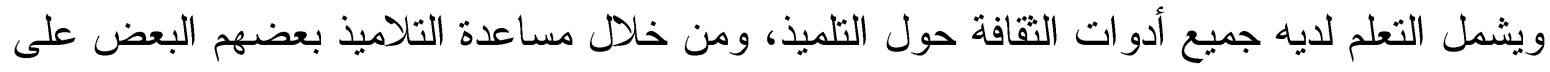

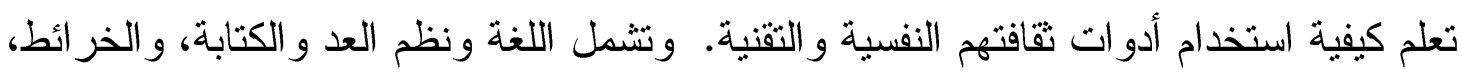

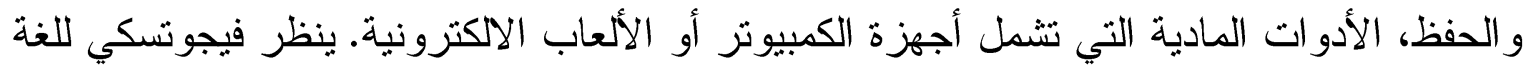

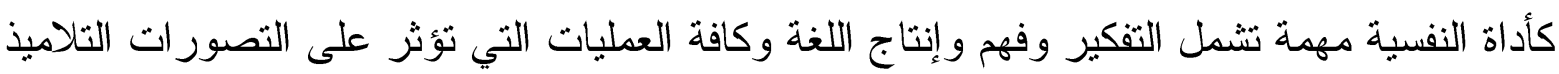
لعو المهم الاجتماعية أخير اركزت النظرية على الناحية الاجتماعية و الثقافية للتلاميذ. (Kozulin) 


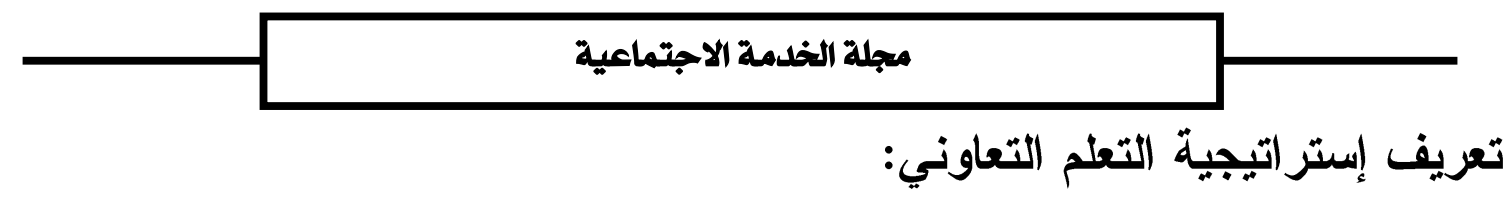

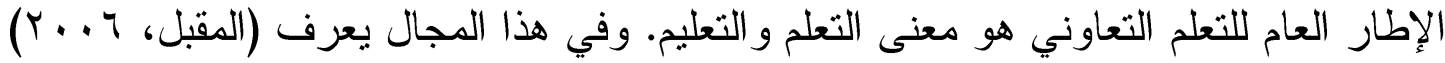

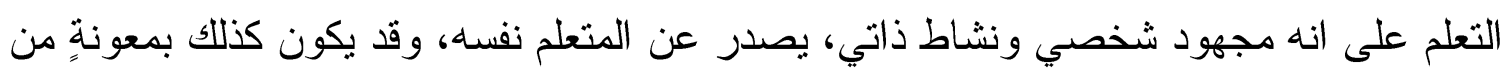
المعلم وإرشاده. كما يعرف التعليم بأنه مجرد مجهود شخصي لمعونة شخص آخر على التعلم. و التعليم هو عملية حفز واستثارة لقوى المتعلم العقلية، ونشاطه الذاتي، وتهيئة الظروف المناسبة التي تمكن

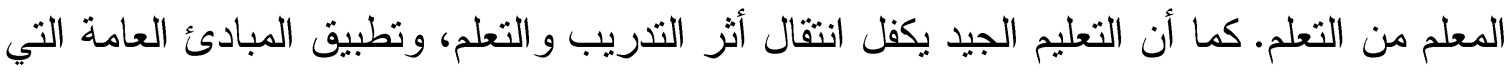
يكنسبها المتعلم على مجالات أخرى ومو اقف مشابهة.

التطبيقات التربوية لإستر اتيجية التعلم التعاوني في مجال تعليم التلاميذ الذين لايهم

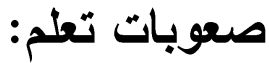
إن الكثير من التلاميذ الذين لديهم صعوبات التعلم ماز الوا يتلقون التعليم باستخدام الطرق التقليدية المبنية على الحفظ و التلقين، و التركيز على نواحي الضعف لديهم، مع إغفال جو انب القوة لديهر.

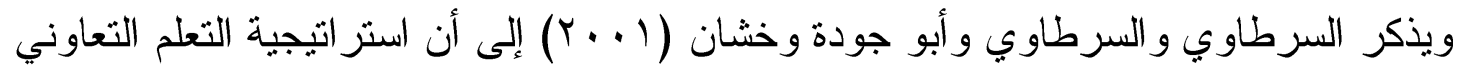
تهدف إلى تحسين الاستيعاب القز ائي بوسائل تزيد من مشاركة التناميذ. كما أنها تعتبر أسلوبا ممتاز أنساً

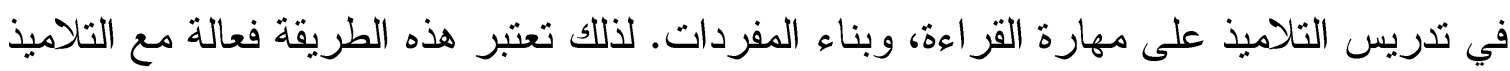

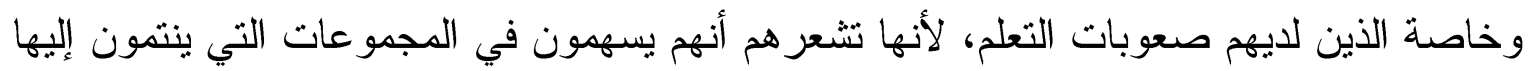
مما يشعر هم بالنجاح.

أسس ومبادئ إستر اتيجية التعلم التعاوني لتعليم التلاميذ الذين لايهم صعويات التعلم: وعند الحديث عن إستراتيجية التعلم التعاوني في تعليم التلاميذ الذين لديهم صعوبات التعلم، يصف (بوتتام Putnam ، ـ99 19 1) عدد من المبادئ و أهمها:

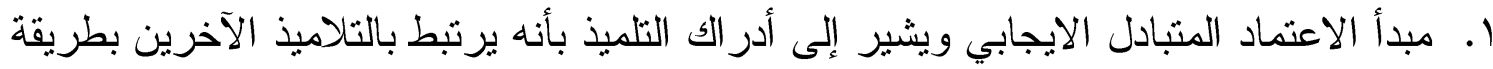

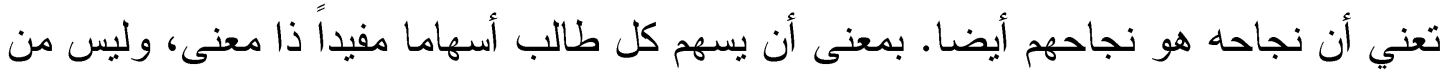

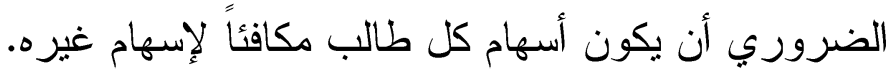

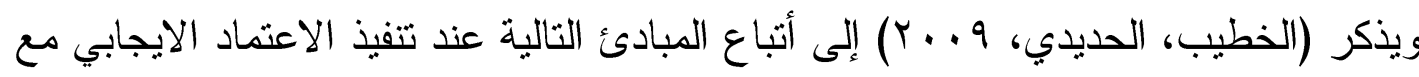
التناميذ الذين لديهم صعوبات التعلم وهي: ألدئ أ- أن يدرك كل طالب أن الهدف هو تعلم جميع التلاميذ في المجموعة. 


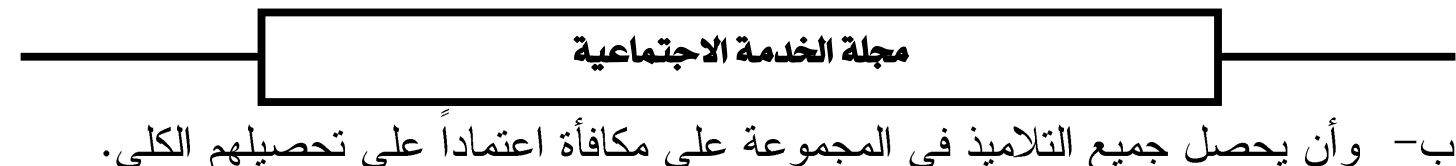

ت- وتوزيع المصادر و المعلومات على التلاميذ، وتجزئة المهمة التعليمية بين التلاميذ.

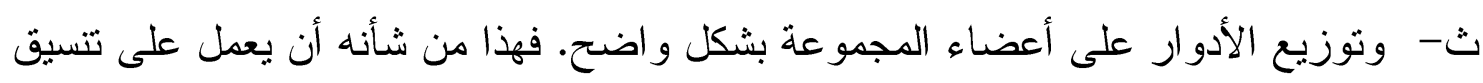
جهود التلاميذ مع بعضهم البعض، بما يسهم في تحقيق الهدف المنشود.

r. مبدأ المساءلة الفردية فيتحقق عندما يتحمل كل طالب في المجموعة مسؤولية كل من التعلم،

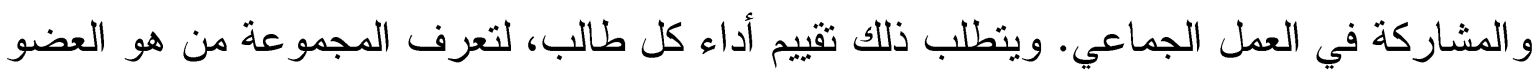

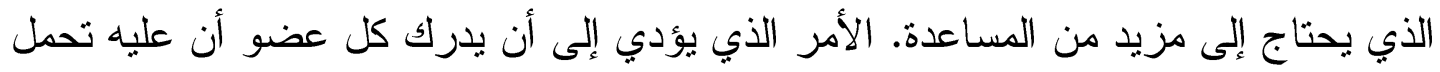

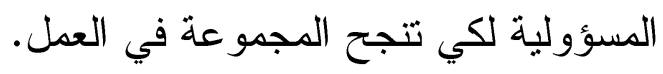

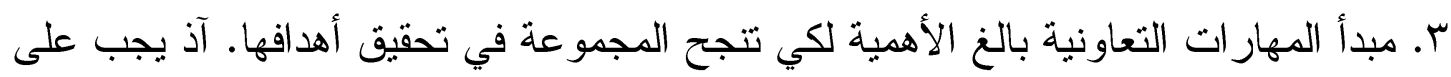

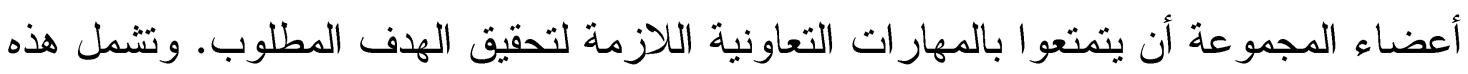

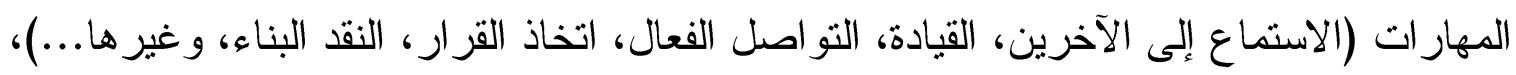

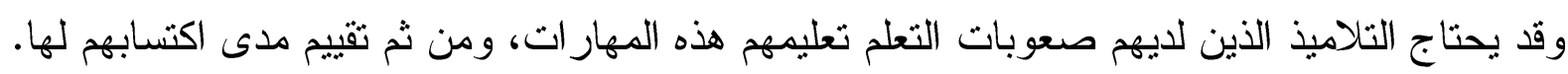

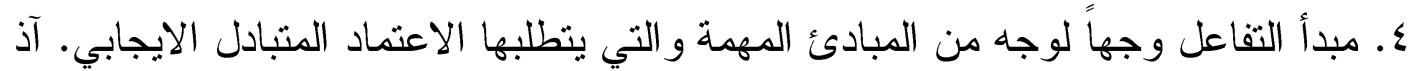

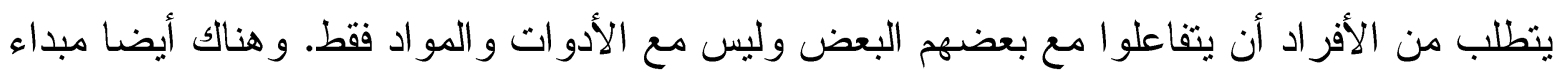

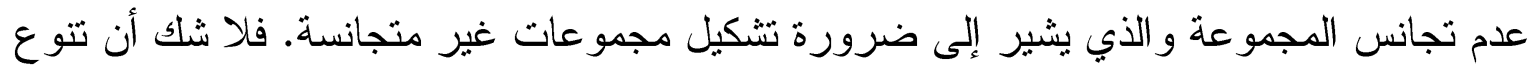

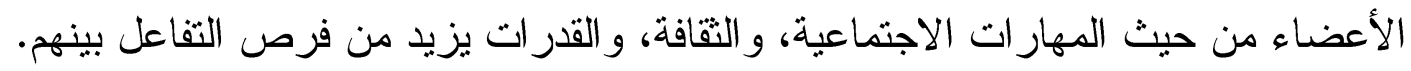

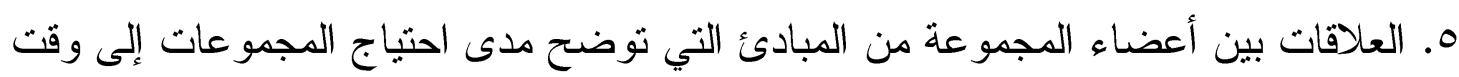

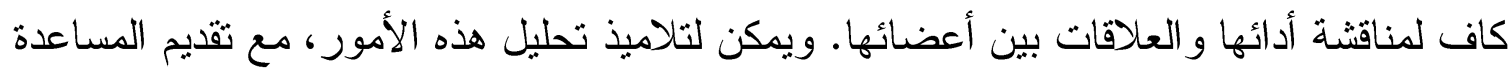
و التغذية الر اجعة التصحيحية من قبل المعلم.

\section{أثنكال التعلم التعاوني عند تعليم التلاميذ الذين لايهم صعوبات التعلم:}

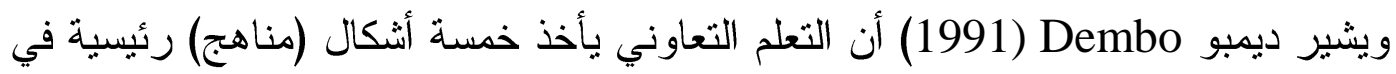

الصف عند تطبيقه مع التلاميذ الذين لديهم صعوبات التعلم. وهي كما يلي:

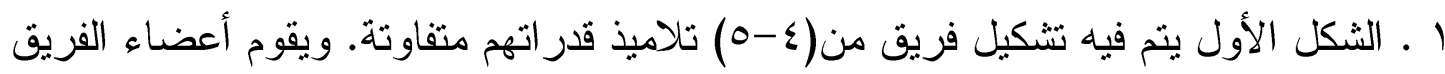

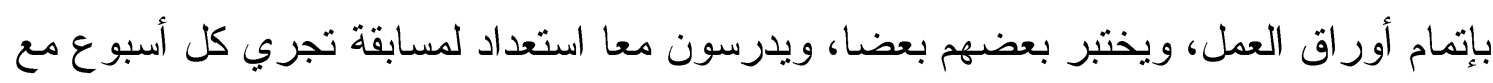

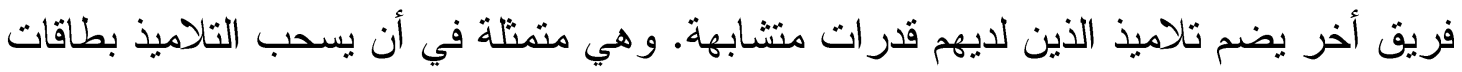

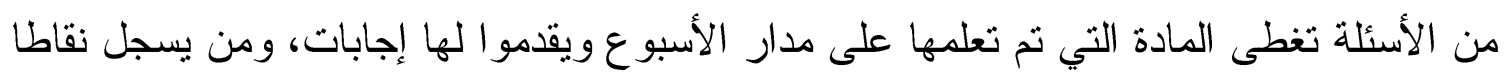

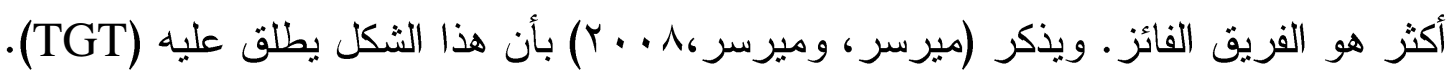

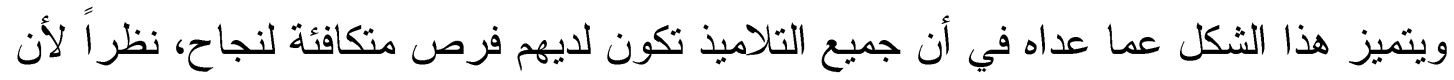

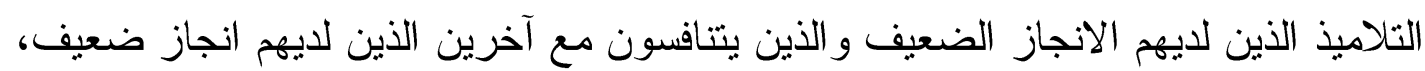




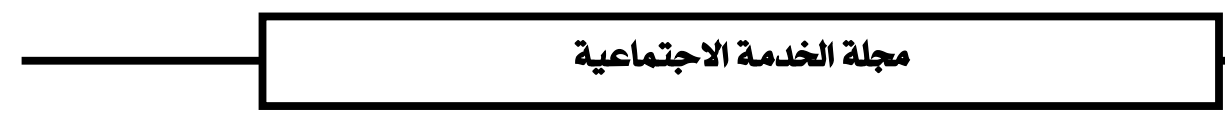

يمكنهم الفوز بنفس عدد النقاط مثل الذين لديهم الانجاز المرتفع الذين يتتافسون مع الذين لديهم

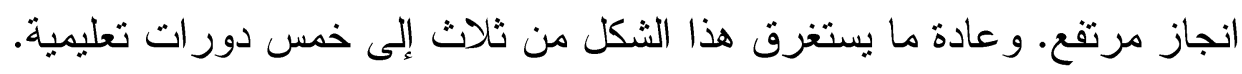

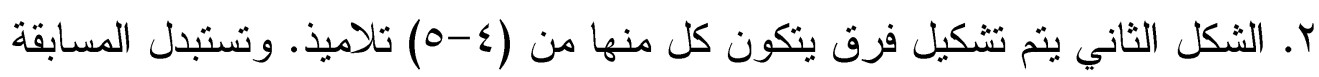

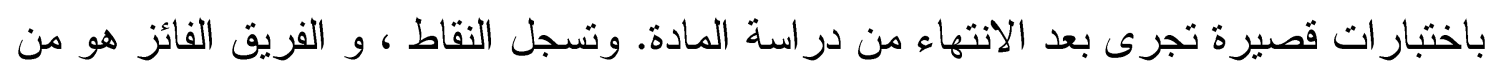

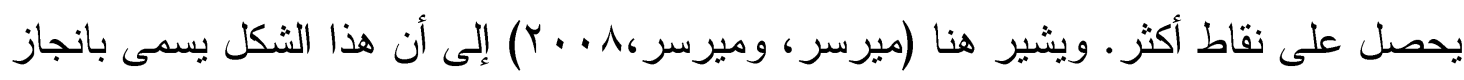

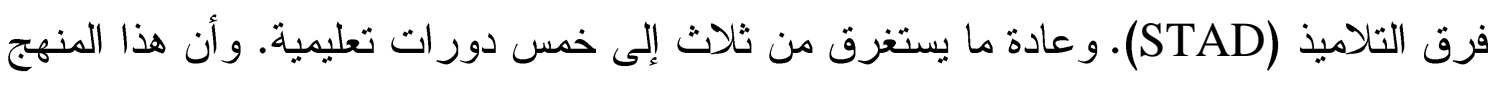

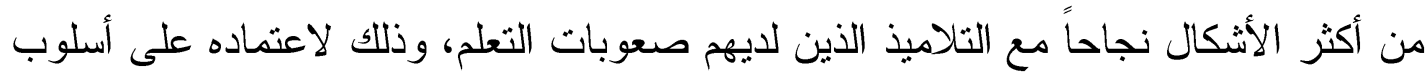

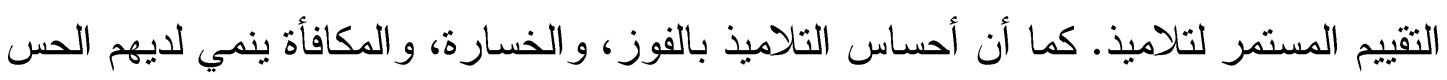
بالمسؤولية تجاه الآخرين.

r. الشكل الثالث يتم تشكيل فرق صغيرة غير متجانسة من التلاميذ، وتوز ع عليهم المادة

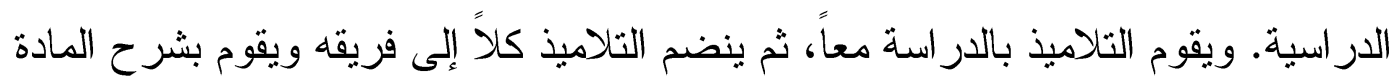

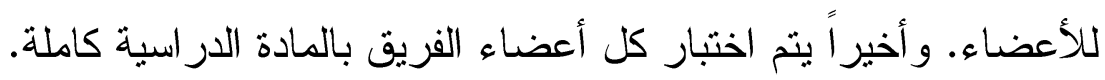

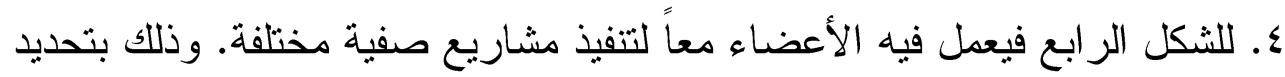

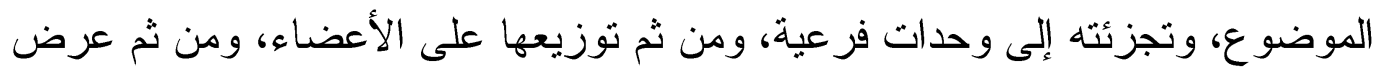

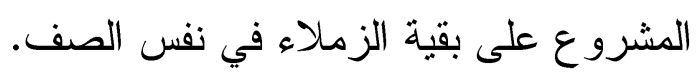
ه. الثكل الخامس يتم تفريد التعليم بمساعدة الفريق، و عادة ما يكون هذا الثكل مجدي عند

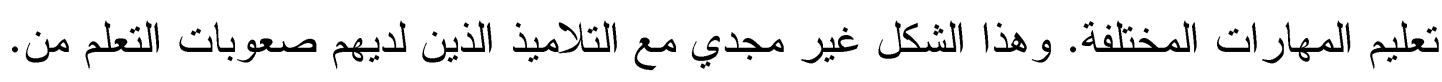
وذلك لكونه قائم على مفهوم التعلم الفردي، كما انه يتضاد مع مفهوم التعلم التعاوني لتلاميذ الذين

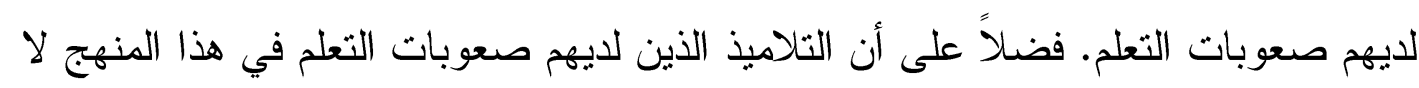

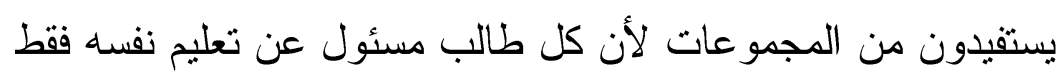

\section{النتائج الايجابية لإستراتيجية التعلم التعاوني على التلاميذ الأين لايهم صعوبات تعلم:}

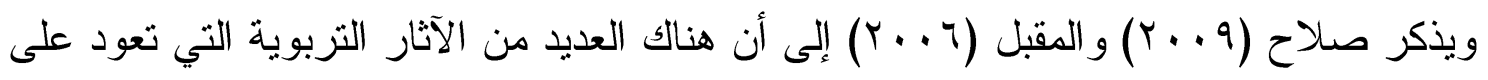

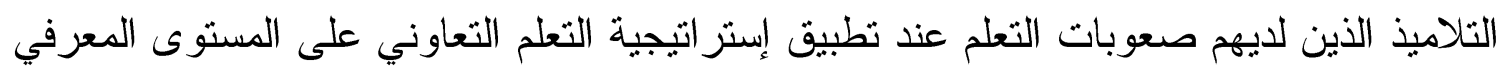

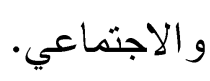

أ- فعلى المستوى المعرفي تتمثل أهم الآثار في مايلي: تتمية أسلوب التعلم الذاتي لدى التلاميذ،

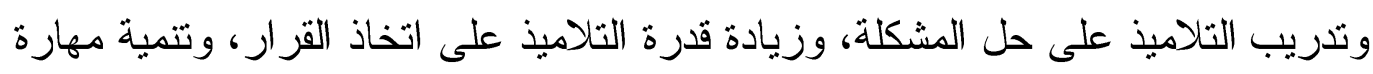

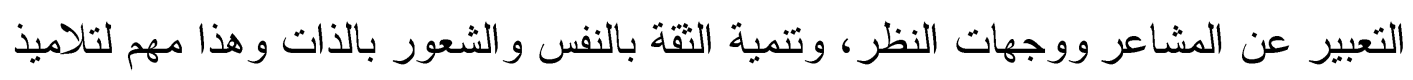

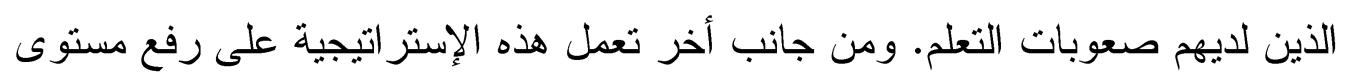




\section{مجلة الخدمة الاجتماعية}

التحصيل الأكاديمي، و التذكر لفترة أطول، وزيادة السلوكيات التي تركز على العمل، وزيادة التوافق النفسي الإيجابي، وزيادة الدافعية الداخلية، والاستعمال الأكثر لعمليات التفكير العليا.

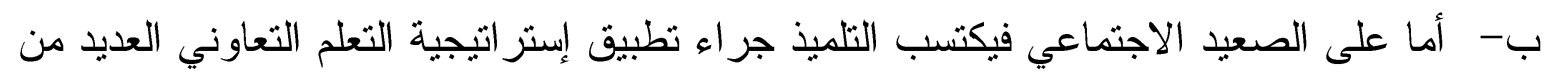

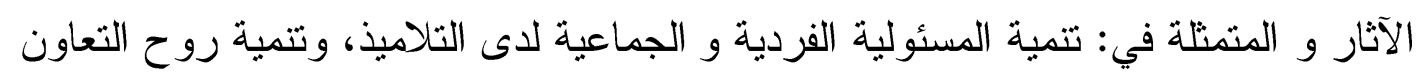

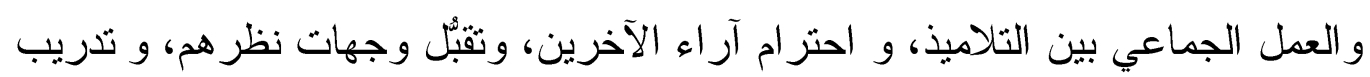

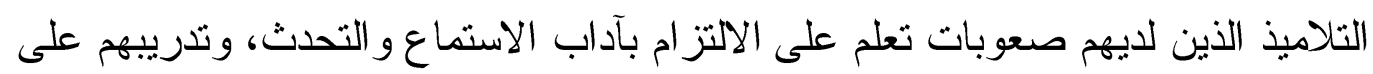

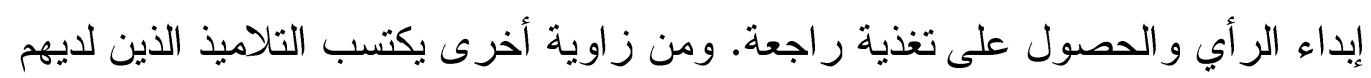

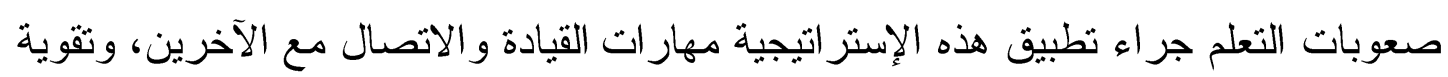

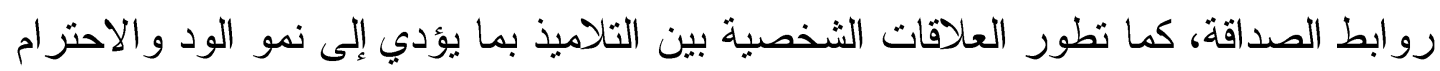
بين أعضاء المجموعة.

\section{خامسا: استر اتيجية خرائط المفاهيم(المعرفية) Concept Mapping إستر اتيجية التدريس الثالثة}

الإطار النظري لإستر اتيجية خرائط المفاهيم:

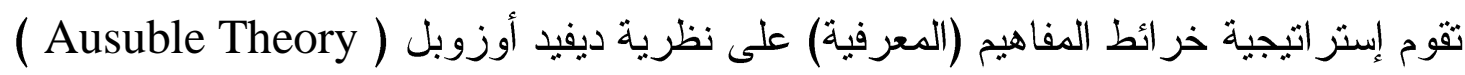

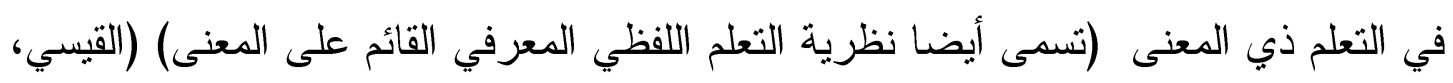

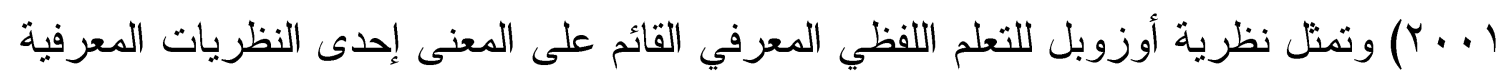
الهامة التي حاولت أن تفسر ظاهرة التعلم من منظور معرفي.

التطبيقات التربوية لنظرية أوزوبل في مجال صعوبات التعلم:

ساهمت نظرية أوزوبل في التعلم بشكل و اضح في المجال التربوي وخاصة في في التخطيط للاروس وتتفيذها وتقويمها، حيث تركز نظريته على الاهتمام بناتج العلم وليس بعمليات التعلم،

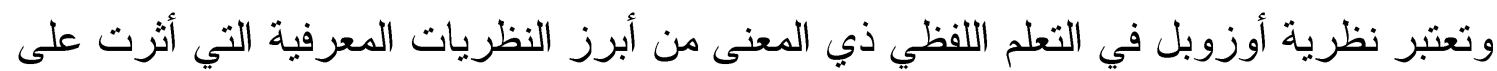
المناهج وطرق التدريس، حيث قدمت تطبيقات تربوية هامة في مجال التعليم و التعلم منها: الاهتمام

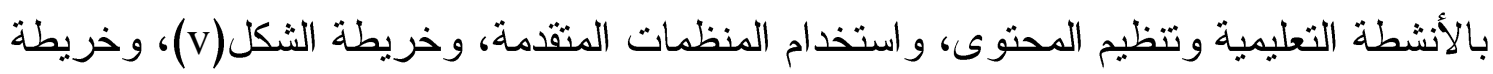

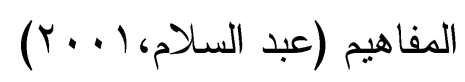

كما أن من أسس النظرية، في أن يكون قادرا على التعلم وهو أحد أهداف التعلم الرئيسة، خاصة

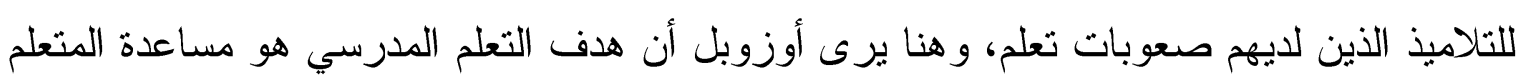

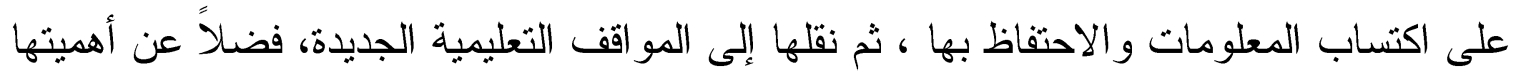




\section{مجلة الخدمة الاجتماعية}

التطبيقية في مجالات التعلم الددرسي الأخرى ، كتخطيط المناهج الدراسية ، وأساليب التدريس ،

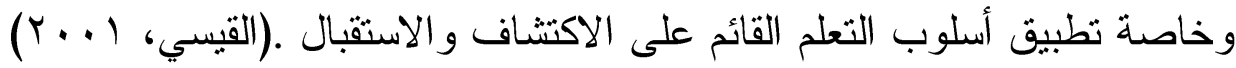

\section{ما المقصود بخر ائط المفاهيم:}

هي عبارة عن رسوم تخطيطية ثنائية البعد تتزتب فيها مفاهيم المادة الدراسية في صورة هرمية

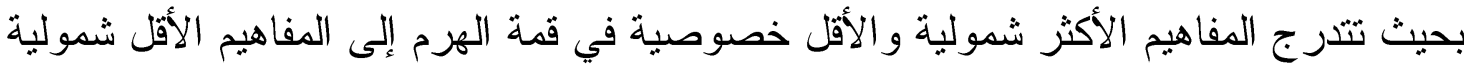
و الأكثر خصوصية في قاعدة الهرم وتحاط هذه المفاهيم بأطر ترتبط باسهر مزودة بكتابات( العريمي $(r+.0$

وقيل إنها وسيلة تخطيطية لتمثيل مجموعة من المفاهيم، موضوعة في إطار من الافتر اضات (

وهي كذلك تنظيم للمعلومات في إثكال أو رسومات تبين ما بينها من علاقات وتتخذ أثكالا مختلفة حسب ما تحويه من معلومات، زمن أمثلة ذلك: أ- خر ائط توضح تسلسل المعلومات. ب- خرائط توضح الفكرة الرئيسة والأفكار المرتبطة بها. ت- خر ائط توضح الأسباب و النتائج. ث- خر ائط تقارن بين فكرتين.

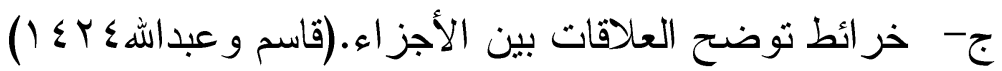
وتعرف خر ائط المفاهيم على أنها تقنية لتمثيل بنية المعرفة وما تتضمنه من مفاهيم وما بينها من tree type علاقات بشكل بصري. وهي عبارة عن تتظيم هرمي لدفهوم عام على شكل شجري

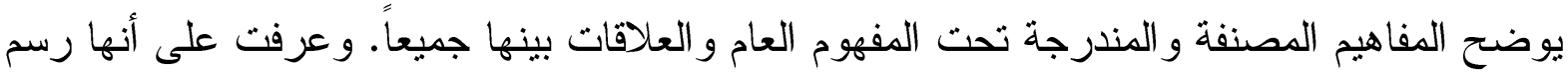
أو شكل تخطيطي يعبر عن العلاقات بين المفاهيم المنضمنة في موضوع ما، فيه تتزتب هذه الدفاهيم

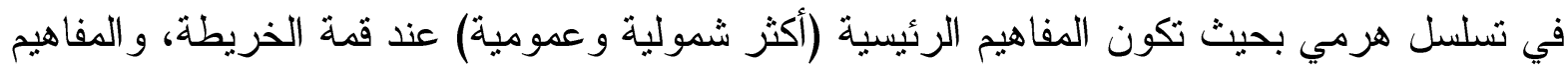
الفرعية (أكثر خصوصية) عند قاعدتها، ويشار من خلاله إلى العلاقات بين الدفاهيم وبعضها البعض

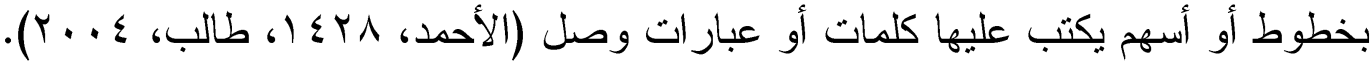

\section{خصائص خر ائط المفاهيم:}

يتعين في التعليم الحقيقي على كل فرد أن يكون لديه معناه الخاص عن الأشباء، فالمتعلمون لا يريدون مزيدا من المضمون، بل يريدون معنى. و احد الأشياء التي يقوم بها المعلم هي فهم أهمية تكوين معنى لدى المتعلمين، بالإضافة إلى توفير البيئة الضرورية وكل الممارسات أو الأساليب التي تؤكد المعنى، لذا فان بنية خريطة المفاهيم وخصائصها تكمن داخل فكرة رئيسية تتفرد بها هذه 


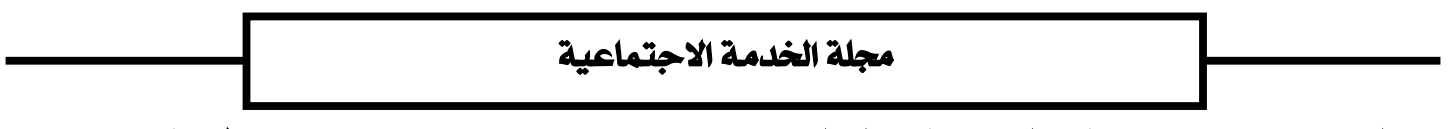

الخريطة عن غير ها من المنظمات التخطيطية بخصائص تميزها وهي كما ير اها (نوفك جوزيف : () Ero

ا. هرمية: ينبغي أن تكون الدفاهيم الأعم و الأشمل في أعلى الخريطة وتتدرج تحتها المفاهيم الأكثر خصوصية والأقل شمولية.

r. متر ابطة: الجانب الأساسي في بناء الخريطة هي الكلمات و الخطوط و اسهم الربط بين

الكفاهيم.

r. تكاملية: تعد النظرة التكاملية في بناء الخريطة ركنا هاما ترتكز عليه فلسفة ووظيفة الخريطة، ذللك أن هذه النظرة التكاملية هي التي تتجلى عمق أو سطحية الفهم لدى المتعلم ومن خلالها يمكن اكتشاف العلاقات التي كونها المتعلم من المعرفة.

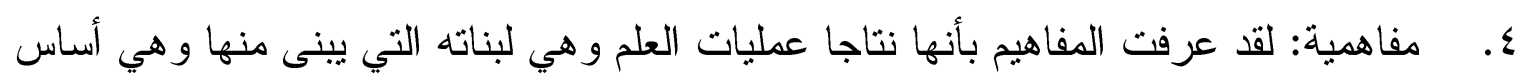

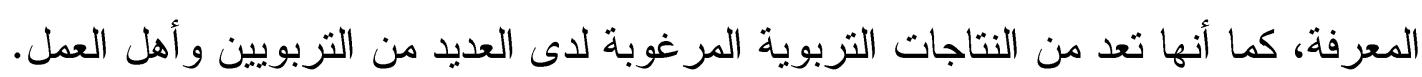

\section{المميزات التربوية لخر ائط المفاهيم}

ا. ا. تنظيم البناء المعرفي و المهاري لاى كل من المعلم والمتعلم. r. ب. توظيف التثنيات الحديثة بالتعليم.

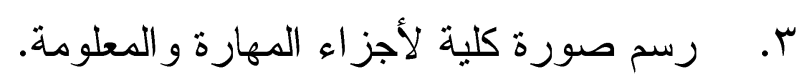

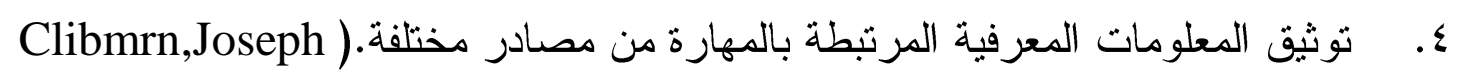

0. مر اعاة الفروق الفردية بين المتعلمين. T.

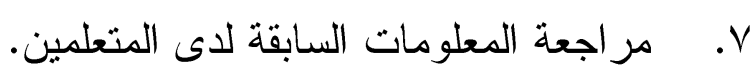
^. سهولة تذكر بنية المهارة التعليمية الكلية.

\section{معايير جودة خريطة المفاهيم:}

هناك العديد من المعايير لتصحيح خريطة المفاهيم و اثشهرها، معيار تصحيح انوفاك زجيوبن وهو: ا. العلاقات: درجة واحدة لكل علاقة صحيحة بين مفهومين.

r. التسلسل الهرمي: خمس درجات لكل تسلسل هرمي صحيح.

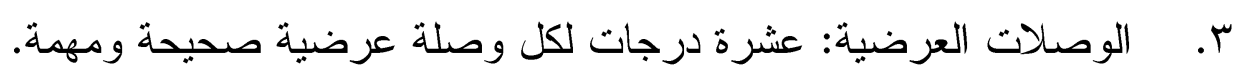

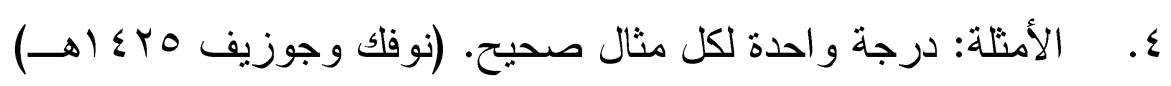




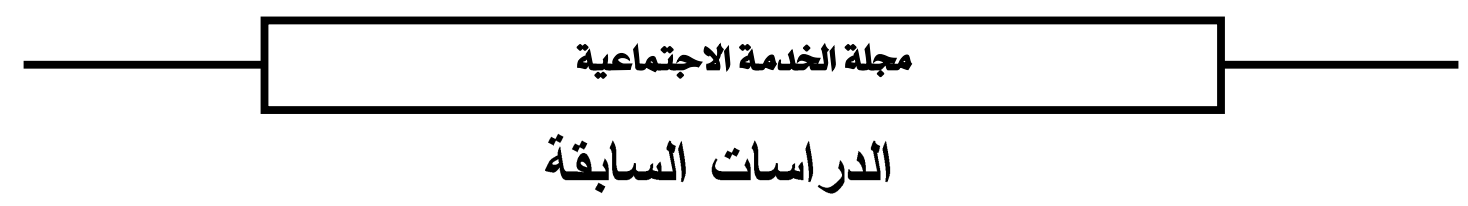

عند الحديث عن استر اتيجيات التدريس ( التدريس التبادلي و التعلم التعاوني وخر ائط المفاهيم ) فإن هناك العديد من الدراسات و البحوث الأجنبية و العربية التي تدعم ما ورد في الفصول السابقة،

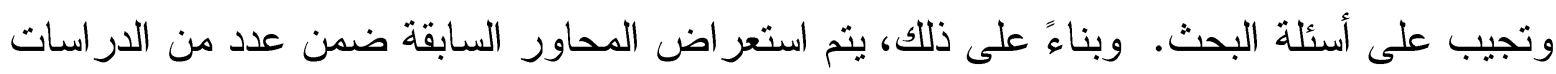

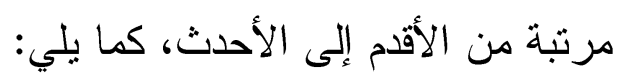
عدد من الدراسات في مجال تدريس التناميذ الذين لديهم صعوبات تعلم، و التي يمكن تصنيفها على لئ

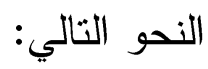

- - دراسات تبين اثر الإستر اتيجية التدريسية المختلفة عامة على تحصيل التلاميذ الذين لايهم

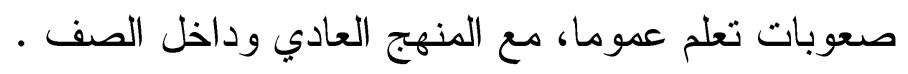
- دراسات تبين اثر إستراتيجية التنريس التبادلي على تحصيل التلاميذ الذين لديهم صعوبات تعلم عموما، مع المنهج العادي وداخل الصف. - دراسات تبين اثر إستر اتيجية التعلم التعاوني على تحصيل التلاميذ الذين لديهم صعوبات تعلم عموما، مع المنهج العادي وداخل الصف. - دراسات تبين اثر إستر اتيجية خر ائط المفاهيم على تحصيل التلاميذ الذين لديهر صعوبات تعلم عموما، مع المنهج العادي وداخل الصف.

\section{التعقيب على الار اسات السابقة :}

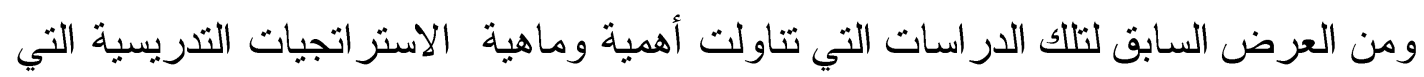

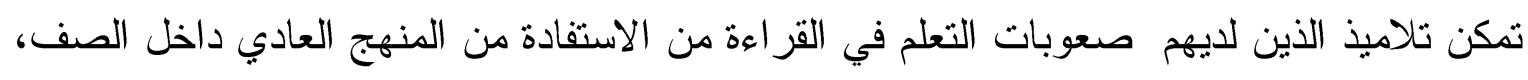

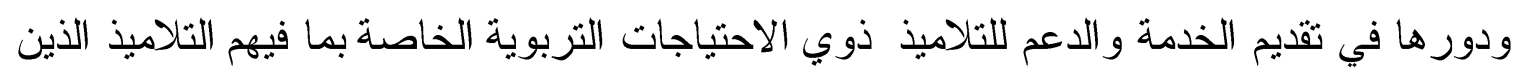
لديهم صعوبات التعلم، يمكننا القول أن الاستر اتيجيات التدريسية (التدريس التبادلي و التعلم التعاوني

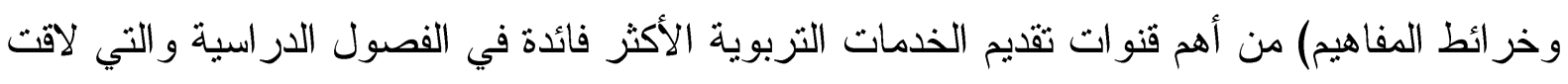

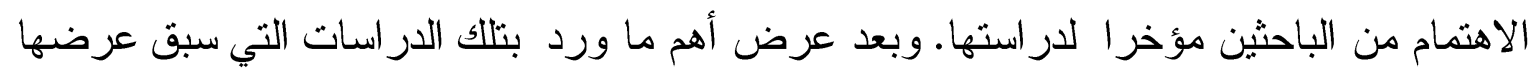

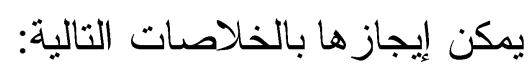
ا.أكدت الدراسات الاستر اتيجيات التنريسية توفر لهؤلاء التلاميذ قدر ا كبير ا من النشاط و الايجابية في

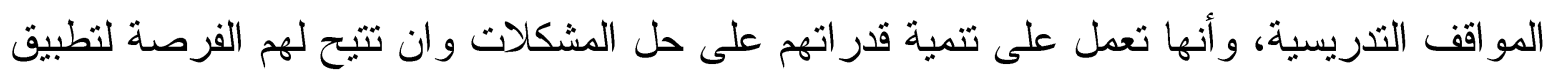
ما تعلموه في مو اقف جديدة. 


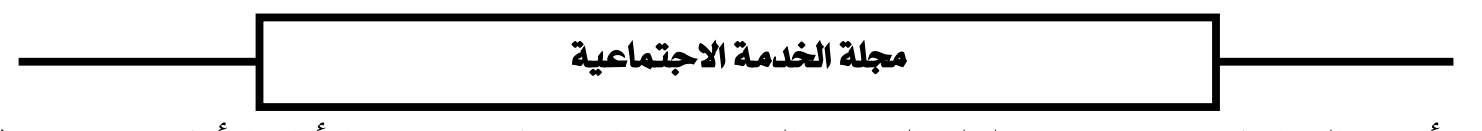

r. أكدت الدر اسات تحسن في سلوك التلاميذ الشخصي و الاجتماعي، وفي الأداء الأكاديمي بعد تطبيق مثل تلك الاستر اتيجيات. r. بينت الدراسات أن تلاميذ صعوبات التعلم غير ميالين بتعلم المزيد من المفردات من خلال أسلوب

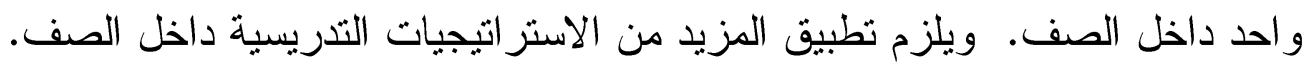

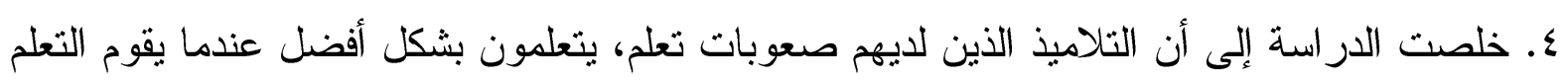
على الملاحظة و الممارسة. على خلاف التلقين الفردي. ه.ووضحت الدراسات أن القر اءة المتكررة كانت أكثر فعالية مع الأقران داخل الصف في في تحسين القر اءة لدى منخفضي اكتساب القراءة وزيادة الدافعية، وتحسن الاتجاه الايجابي نحو القر اءة داخل فئل الصف. T.أثتتث الدر اسات زيادة في متوسط طلاقة القراءة وصحتهاهوتقدير الذات و الثقة بالنفس بعد استخدام تلك الاستر اتيجيات التدريسية . V. الأثر إلى الاستر اتيجيات التدريسية المستخدمة على التلاميذ الذين لايههم صعوبات تعلم في القراءة، و أنهم استفادوا من التخخلات العلاجية داخل الصف، وضمان عدم تسرب هؤلاء التلاميذ من الصف الدر اسي ^. أكدت دراسات التي قامت على إستر اتيجية التنريس التبادلي على التالي:

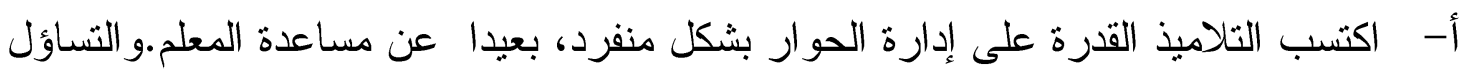

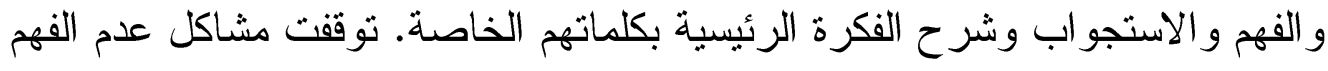
و الأفكار الغير و اضحة و الجمل المشتخة. ب- أسفرت الدراسات عن تقدم كبير في القراءة و الفهم وفي اللغة الثفهية للتلاميذ الذين لديهر

$$
\text { صعوبات نعلم. }
$$

ت- التأثير الايجابي لإستر اتيجية التدريس التبادلي على مهارات الفهم القرائي و الوعي القرائي و

$$
\text { الاستيعاب القرائي. }
$$

ث- تحسن مستوى ما ور اء الفهم وكذللك الفهم القرائي لاى تلامبذ ذوي صعوبات الفهم القرائي.

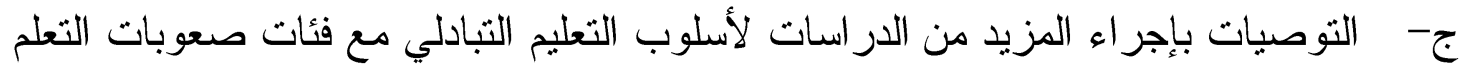

$$
\text { الأخرى (صعوبات الرياضيات، صعوبات الكتابة). }
$$

9. أكدت در اسات التي قامت على إستر اتيجية التعليم التعاوني على التالي:

أ- ارتفاع مستوى العلاقة بين التلاميذ العاديين و التلاميذ الذين لديهم صعوبات تعلم. وازدياد مستوى التحصيل الدراسي في المجموعة التعاونية مقارنة بالمجموعة الفردية. ب- تفوق التعلم التعاوني على التعلم التقليدي. 
ت- تحصيل التلاميذ الذين درسو ا بأسلوب التعلم التعاوني أعلى من من درسو ا بالأسلوب التقليدي. بالتحصيل الدراسي ككل ومستويات التذكر و الفهم و التطبيق. ث- الحصول على أداء أعلى بكثير على استبيان الفهم القرائي.

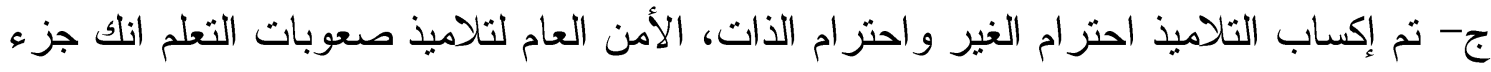
من مجموعة، ارتفاع النتائج النهائية ومعدلات النجاح الأكاديمية. و المساعد في تلبية

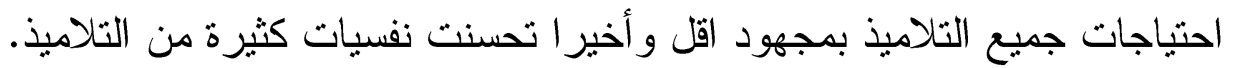
ح- المهار ات الاجتماعية وتقدير الذات.

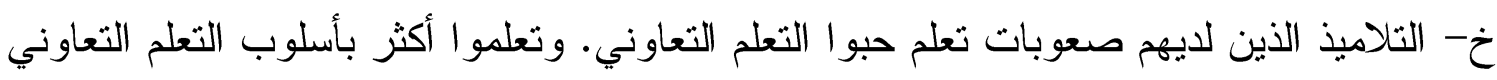

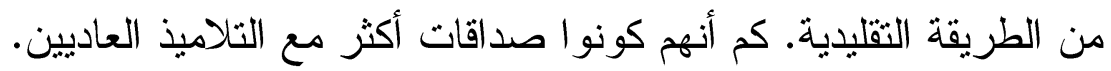
• 1. أكدت دراسات التي قامت على قياس أثر إستر اتيجية خر ائط المفاهيم على التالي:

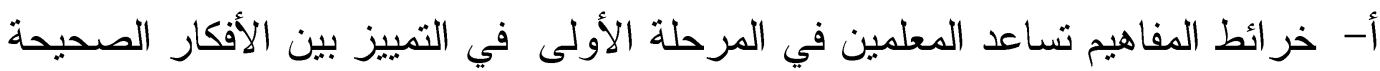
و الأفكار الخاطئة عند الطلبة.

ب- يساعد المعلمين كذلك في التخطيط للاروس بتوضيحها للمفاهيم وتسهيل تسلسل التعلم لاى

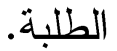

ت- - للتلاميذ الذين لديهم صعوبات تعلم في القراءة تتيح فهم المعلومات المعقدة و المفاهيم الصعبة وتزتيبها بشكل منظم وتمييز المفاهيم الجديدة والربط بينها وبين الدفاهيم السابقة. وتحديد

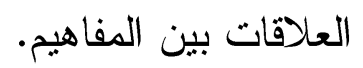
ث- أنها تساعد على الاحتفاظ بالمعرفة لفتر ات طويلة من الوقت. ج- فاعلية التدريس بخر ائط المفاهيم وزيادة التحصيل وتتمية الاتجاهات العلمية للتلاميذ المتأخرين در اسيا.

ح- تطوير أنماط تفاعلهم اللفظي فيما بينهم من جهة، وبنتهم وبين معلميهم من جهة أخرى.

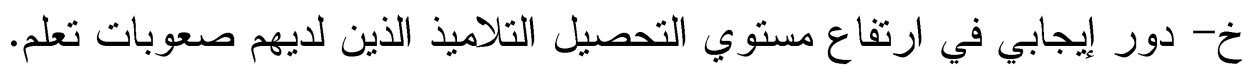

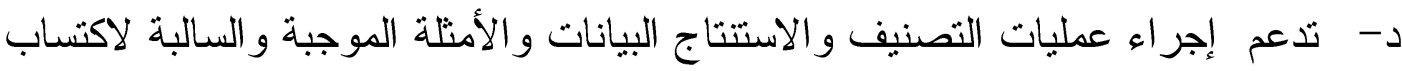

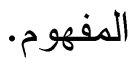

1 ا ـ اهتمت غالبية الدر اسات بذكر الفو ائد المتعددة لتطبيق الاستر اتيجيات التدريسية الثلاث، و أثرها الايجابي على جميع المشاركين من معلمين وجميع تلاميذ الفصل بما فيهم ذوب صعوبات التعلم، ومنها أنها تدعم نجاح ونمو التلاميذ في النواحي الدر اسية و السلوكية و الاجتماعية. 


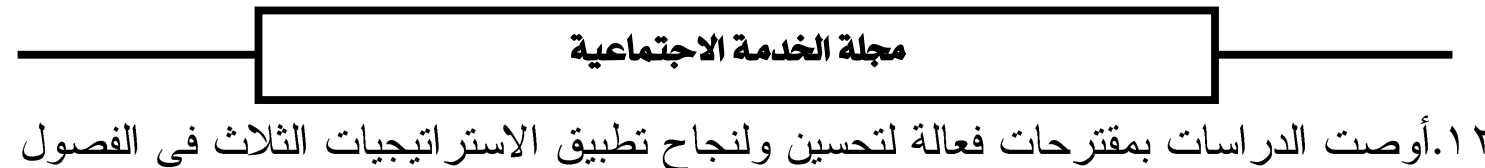
الدراسية المحتوية على التلاميذ ذوي صعوبات تعلم وللتغلب على العقبات و التحديات التي تو اجه تطبيقه.

با ا. ركزت غالبية الدر اسات على التلاميذ العاديين و المتأخرين در اسيا، وعلى مادة العلوم و الجغر افيا. ولم تركز على آراء ووجهات نظر المعلمين، ولم تقوم بالتحليلات واقعية لحاجة الميدان.

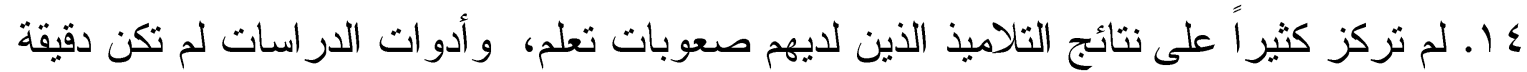

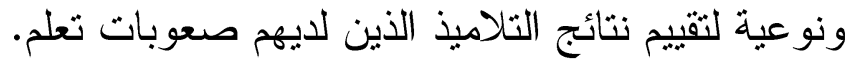

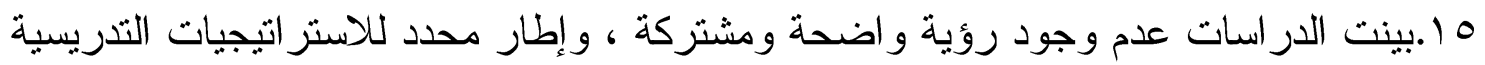
الثلاث، مر احلها وأسس تطبيقها داخل الفصل، ومهام المعلم والتلاميذ الذين لايهم صعوبات تعلم.

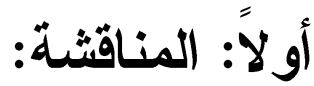

إن بقاء التلاميذ الذين لديهم صعوبات تعلم داخل الصف العادي، وتقديم منهج موحد لجميع التلاميذ داخله. أمر يطلب تغيير استر اتيجيات التدريس المستخدمة داخل الصف من قبل المعلم. وطرق أخرى جديدة تتتاسب مع خصائص التلاميذ المختلفة وتلبي فروقهم الفردية، لنكون مخرجات التعليم في

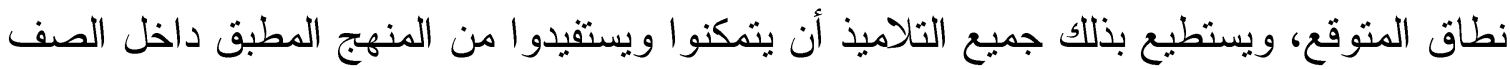
على اختلاف خصائصهم واحتياجاتهم.ونتيجة للنأثير ات المختلفة على التلاميذ الذين لديهر صعوبات تعلم وأهاليهم، والمعلمين وحتى الأقران و البيئة الصفية، تم طرح أربعة أستونة أسئلة حول فاعلية الاستراتيجيات المختلفة على قدرة التلاميذ الذين لديهز صعوبات تعلم على الاستفادة من المنهج العادي.

السؤال الأول كان حول تأثير الإستر اتيجيات التدريسية المختلفة على تمكين التلاميذ الذين لايهم صعوبات تعلم عموما، و التلاميذ الذين لديهم صعوبات تعلم في القراءة خصوصا على الاستفادة من

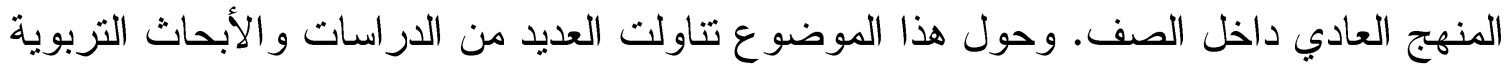
التي أجريت للتأكد من فاعلية استر اتيجيات تدريسية مختلفة على التلاميذ عموما و على التلاميذ الذين

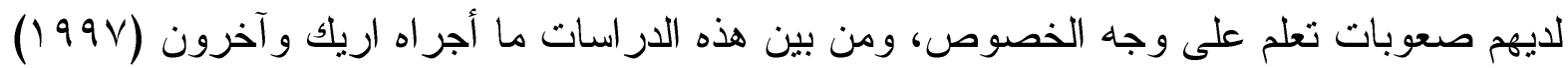
( Eric, et al,

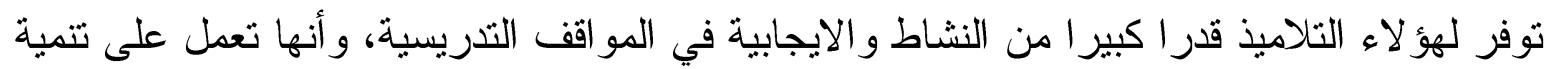
قدر اتهم على حل المشكلات و أنها تتيح لهم الفرصة لنطبيق ما تعلموه في مواقف جديدة، كما أثنتي

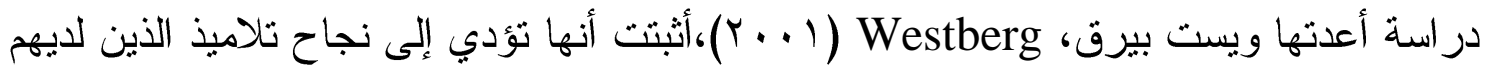




\section{مجلة الخدمة الاجتماعية}

صعوبات التعلم في الأداء الأكاديمي عند تطبيق استر اتيجيات تدريسية تتاسب احتباجاتهم. و أيضا في

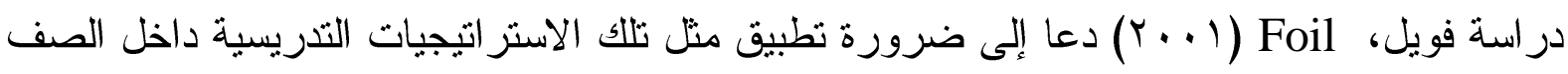

و استخدامها مع تلاميذ الذين لديهم صعوبات تعلم وتطبيق المزيد، وكذلك أكدت در اسة قامت بها روس، Ross ( ( . r ) على أن التلاميذ يتعلمون بشكل أفضل عندما يقوم التعلم على استر اتيجيات

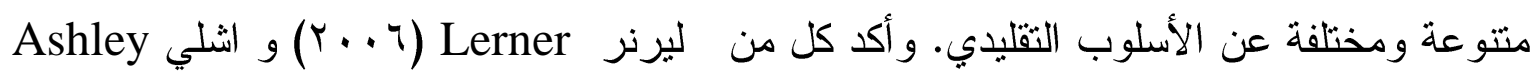

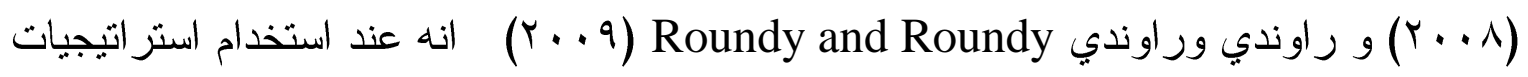
تدريسية جديدة مع التلاميذ الذين لديهم صعوبات تعلم داخل الصف يتحسن لديهم التعرف التلقائي على الكلمة ونسبة التصحيح الذاتي للأخطاء والفهم و الطلاقة في القراءة وتحسن الاتجاه الايجابي نحو القز اءة داخل الصف.

و أما بخصوص السؤال الثاني و الذي كان حول تأثير إستر اتيجية التدريس التبادلي على تمكين التلاميذ الذين لديهم صعوبات تعلم عموما، و التالاميذ الذين لديهم صعوبات تعلم في القر اعة خصوصا على الاستفادة من المنهج العادي داخل الصف ـ فيوضحه ما قامت به الباحثتين بالينسار وبروان، Palincsar and Brown (ع^9 ( ) حيث تبين انه بعد استخدام إستراتيجية التدريس التبادلي داخل الصف مع التلاميذ الذين لديهم صعوبات تعلم ازداد التساؤل عن الفكرة الرئيسة في النص المقروء بنسبة ، V\% من قبل التلاميذ الذين لديهم صعوبات تعلم في القراءة. كما اتضح قلة الأخطاء من 9 (\% إلى • (\% فيما يخص القراعة. ومع تكرار التفاعل و إعادة صياغة الأنشطة القرائية، استطاع التلاميذ التقدم و أداء تلك الوظائف باستقلالية. وكذلك اكتسب التلاميذ القدرة على إدارة الحوار بشكل منفرد عن المادة المقروءة، بعيدا عن مساعدة المعلم.و التساؤل و الفهح و الاستجو اب وشرح

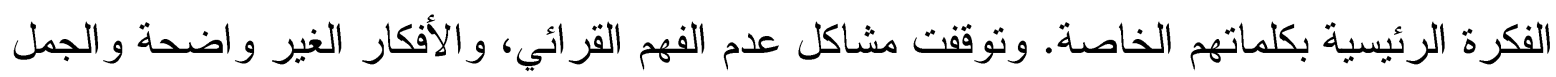
المشتنة. وأخير الوحظ تقدم واضح لاى التلاميذ في الواجب اليومي لقطع القر اءة في جلسات التدريس التبادلي. كما تبين من در اسة كلاينقنر وفاون، Klingner and Vaughn (1997 ( ) إن هناك تقدما كبير إي القراعة والفهم بعد استخدام إستر اتيجية التدريس التبادلي ، كما وقد اظهر التلاميذ تقدما اكبر

مع الحد الأدنى لدعم الكبار • وتقدما في اللغة الثفهية والاستقبالية. هذا وقد أكدت در اسة قام بها

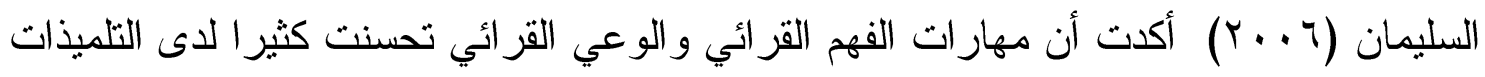
اللاتي لديهن صسوبات تعلم في القر اءة بعد تطبيق برنامج التدريس التبادلي عليهن. وفي نفس السياق أكد أيضا عيسى (V V. . . على تحسن مستوى ما ور اء الفه وكذلك الفهم القرائي لدى التلاميذ الذين لديهم صعوبات تعلم في القراءة، بعد استخدام إستر اتيجية التدريس التبادلي وأيضا أوضح خالد

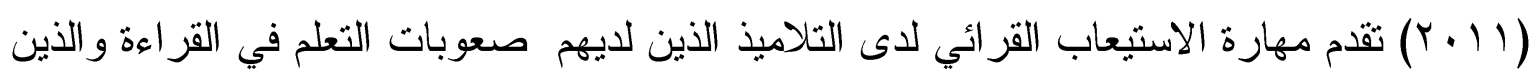




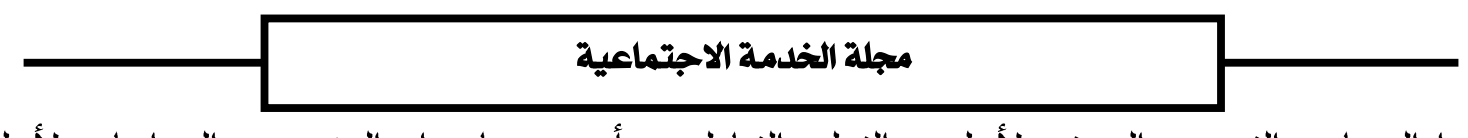

تلقو البرنامج التدريبي المستند لأسلوب التعليم التبادلي، وأوصت بإجر اء المزيد من الدراسات لأسلوب التعليم التبادلي مع فئات صعوبات التعلم الأخرى (صعوبات التعلم في الرياضيات وفي الكتابة).

وبخصوص السؤال الثالث و الذي كان حول تأثير إستر اتيجية التعلم التعاوني على تمكين التلاميذ

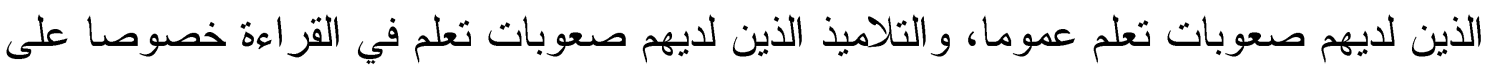

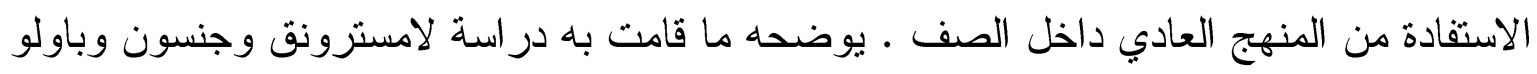
Armstrong , Johnson, Balow العاديين و التناميذ الذين لديهم صعوبات تعلم. و ازدياد مستوى التحصيل الدر اسي للتناميذ الذين لاديهم

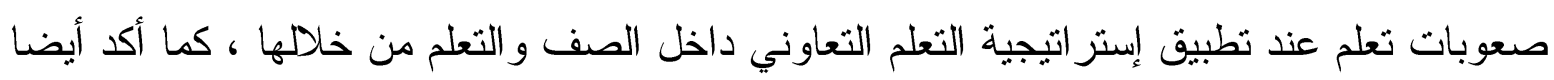

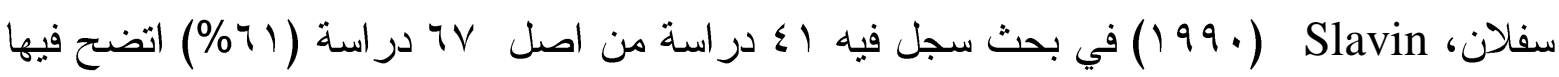
تفوف التعلم التعاوني على التعلم التقليدي، واختلفت نتائج الدراسات في مقدار الأثر الناتج، تبعا للعاملين

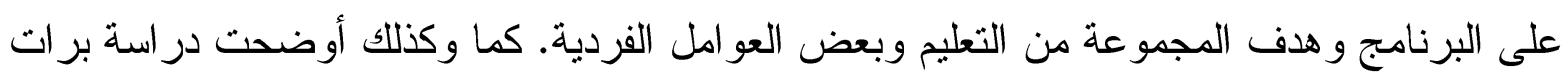
ومويزنر Pratt , Moesner ( •99 19) أن التلاميذ عموما يبدون تفاعلا وحماسا اكبر للتعلم التعاوني أكثر مما يظهروه في التعلم التقليدي، إلا أن التلاميذ ذوو التحصيل المتدني كانوا القل حماسا وتفاعلا

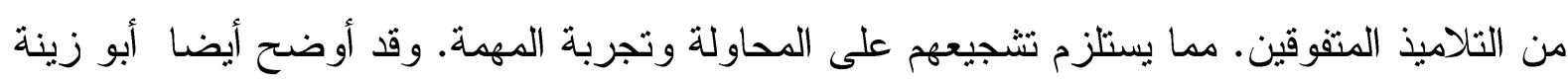
وخطاب (ب99 (19) في در استهما أن تحصيل التلاميذ الذين درسو ا بأسلوب التعلم التعاوني بالرياضيات

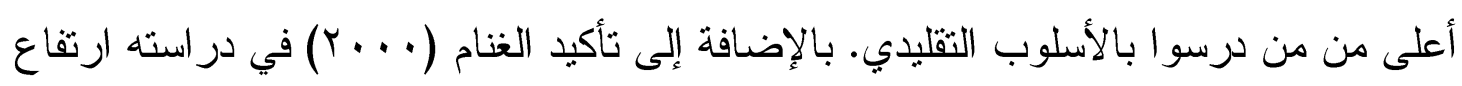

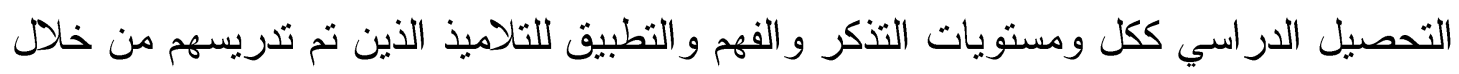

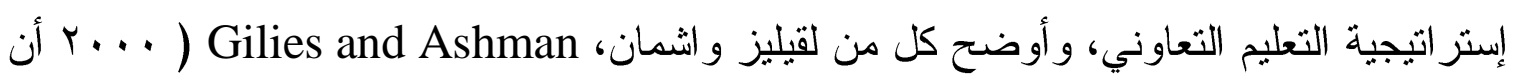

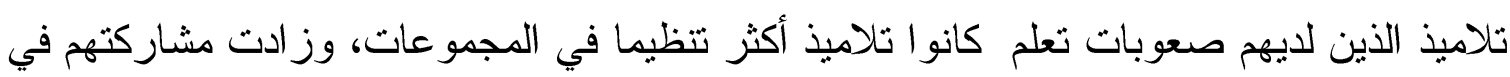

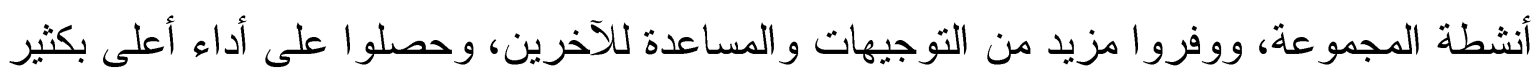

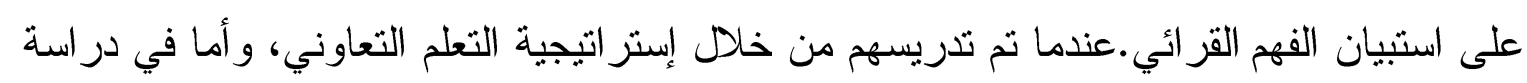

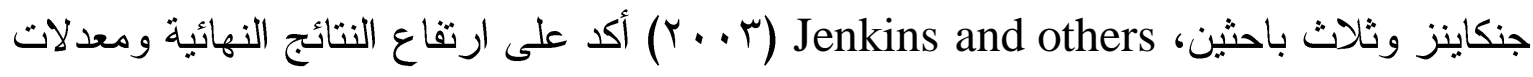
النجاح الأكاديمية.بالنسبة للتلاميذ الذين لديهم صعوبات تعلم و الذين تم تدريسهم من خلال إستر اتيجية

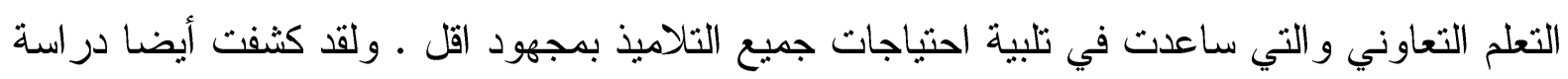

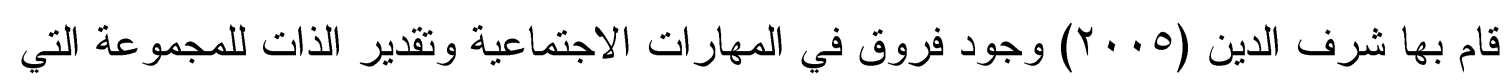

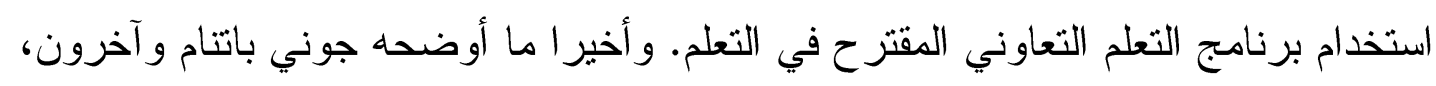
Putnam and others

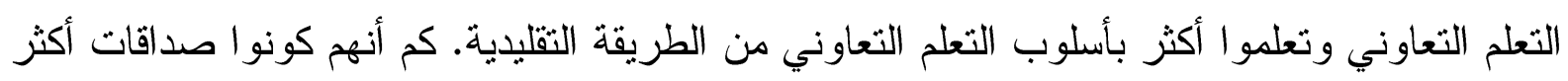
مع التلاميذ العاديين. 


\section{مجلة الخلمة الاجتماعية}

أما بخصوص السؤال الرابع و الذي كان حول تأثير إستر اتيجية خر ائط المفاهيم على تمكين

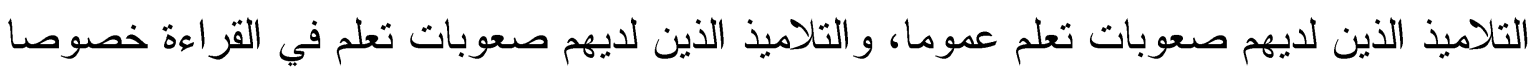

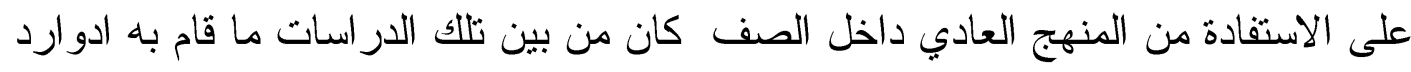
وفريزر، Edwards and Fraser (9Av ) حيث أكدا أن استخدام خر بئط لمفاهيم يساعد المعلمين

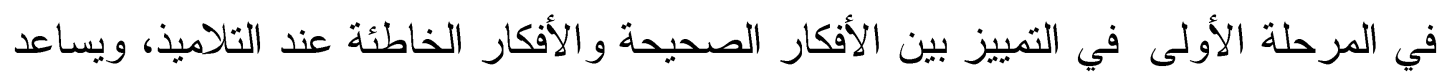

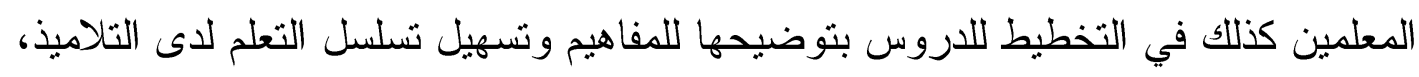

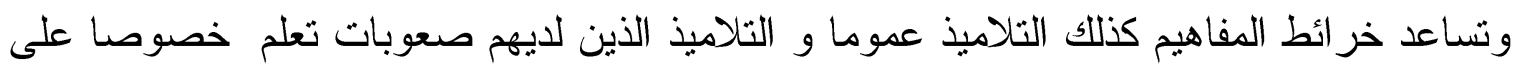
فهم المعلومات المعقدة و المفاهيم الصعبة وترتيبها بشكل منظم وتمييز المفاهيم الجديدة و الربط بينها

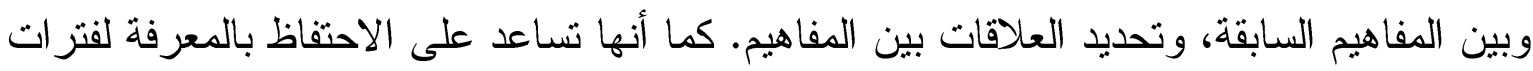

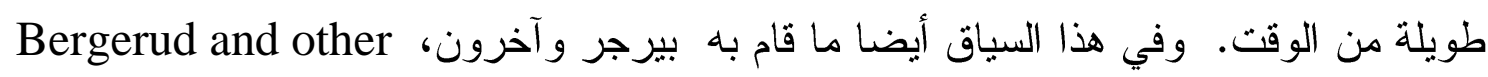

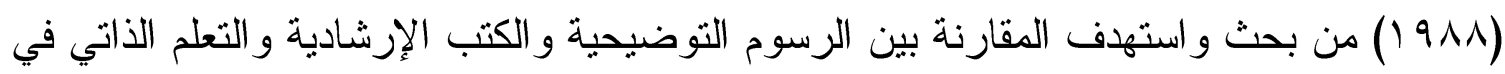

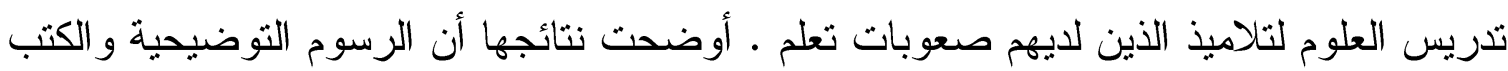

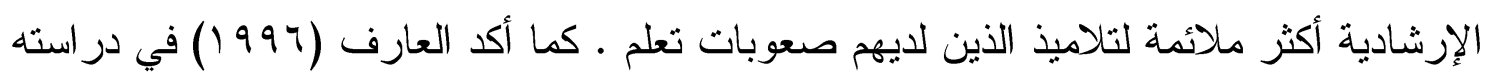

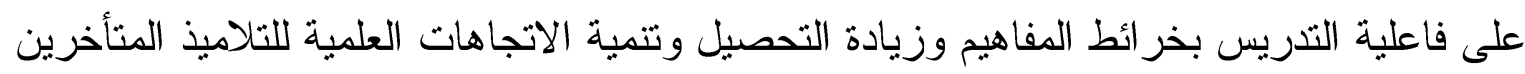

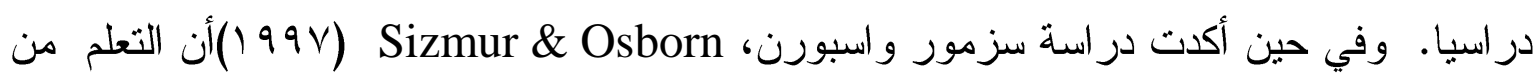

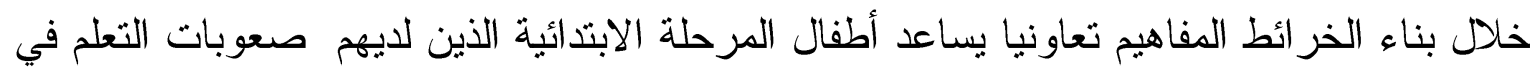

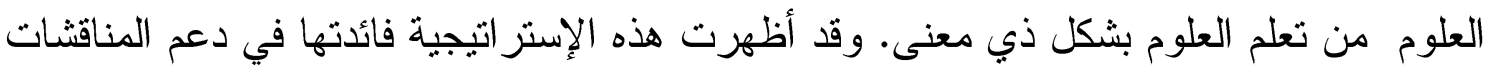
المجموعات الصغيرة من التلاميذ للأفكار العلمية وتطوير أنماط تفاعاهم اللفظي فيما بينهم من جهة فئه

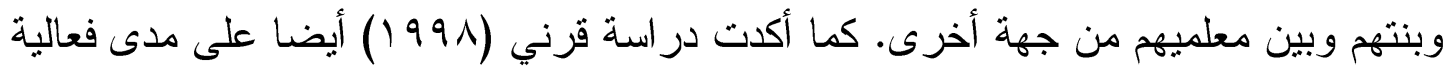
الندريس بخر ائط المفاهيم علي التحصيل العلمي عموما، و التحصيل في مستويات (التذكر - الفهر -

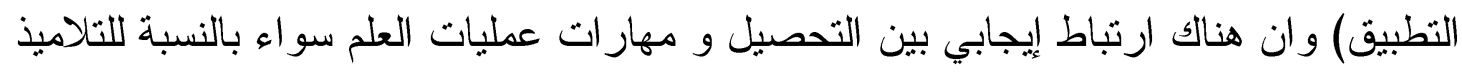

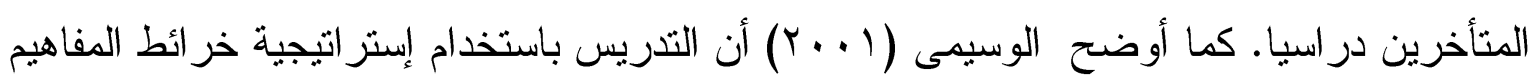
أفضل من التدريس بالطريقة التقليدية " المعتادة " فيما يتعلق بالتحصيل و الاحتفاظ بالتعلم و الاتجاه

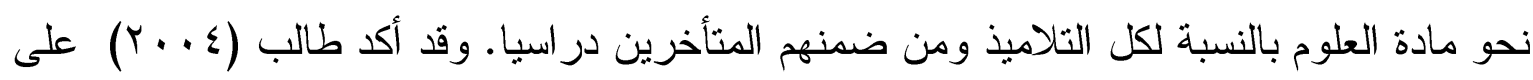

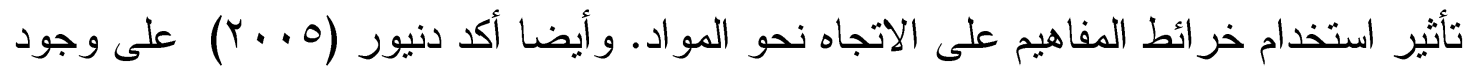

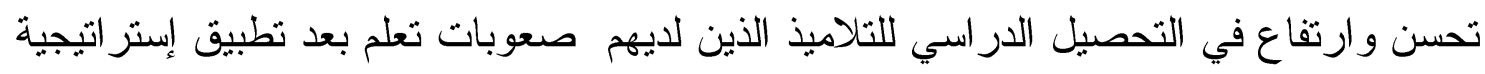

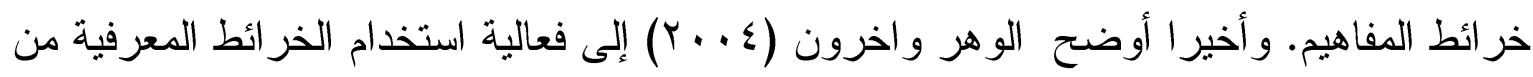

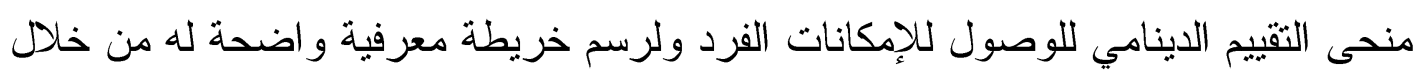
استخدام الوصف الإكلينيكي للتناميذ الذين لديهم صعوبات تعلم وللتناميذ الذين لديهم إعاقة عقلية. 


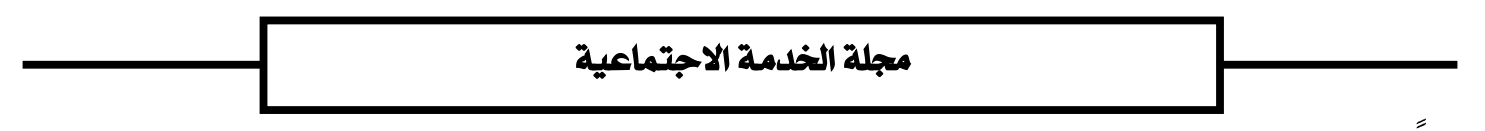

ثانياً: الخلاصة :

يتضح مما تقدم أن الاستر اتيجيات التدريسية المتتوعة و التي من ضمنها إستر اتيجية التدريس

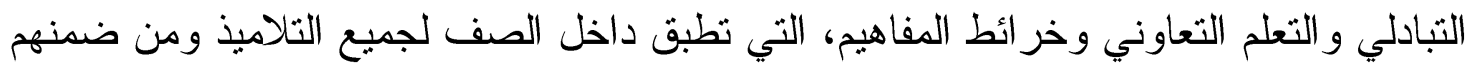

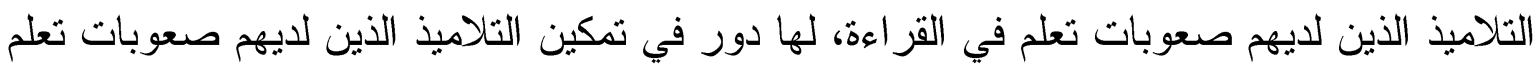

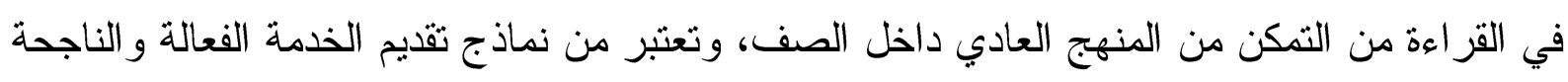

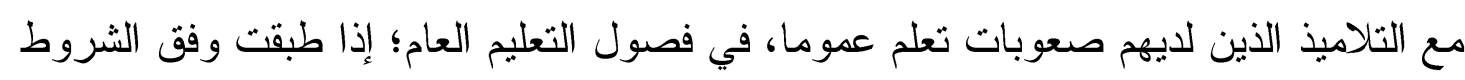

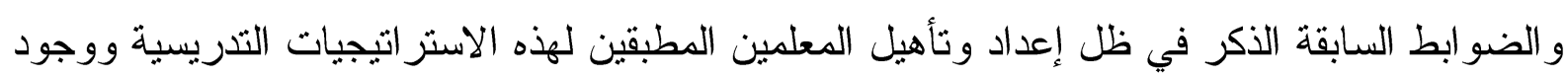

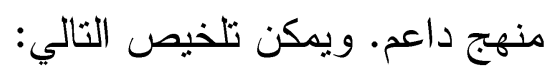

ا. إن الاستر اتجيات التدريسية المتتوعة توفر للتناميذ الذين لايهم صعوبات تعلم في القراءة،

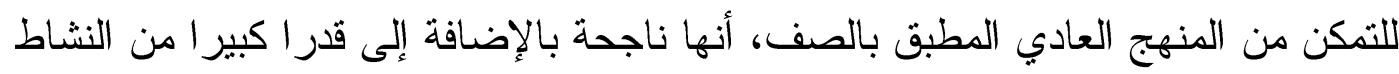

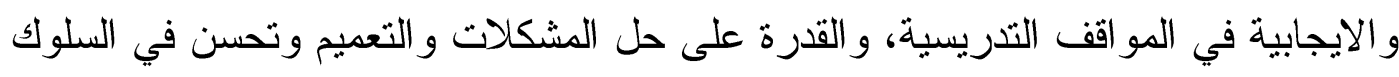

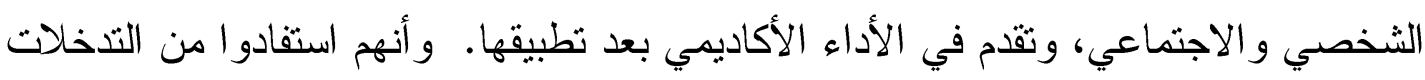

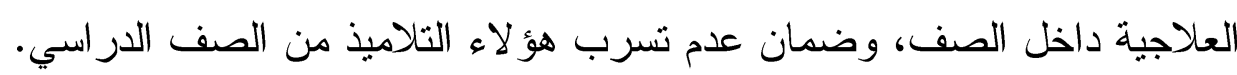

r. أكدت الدراسات التي طبقت إستر اتيجية التدريس التبادلي على التلاميذ الذين لايهر صعوبات

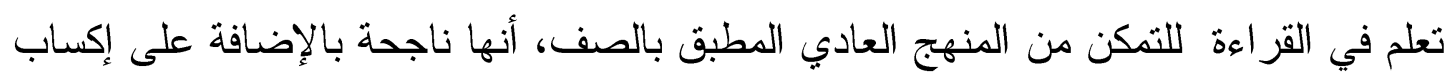

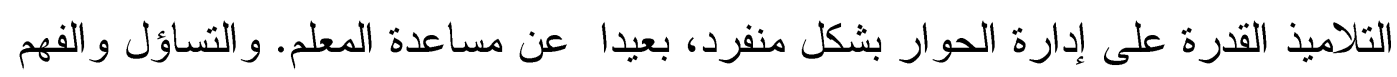

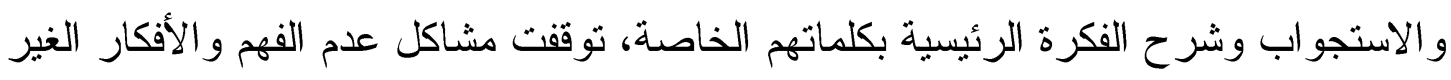

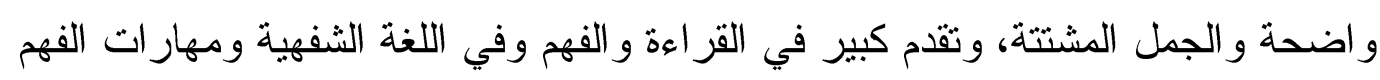
القر ائي و الوعي القر ائي و الاستيعاب القرائي.

r. أكدت الدراسات التي طبقت إستر اتيجية التعلم التعاوني على التلاميذ الذين لديهر صعوبات تعلم

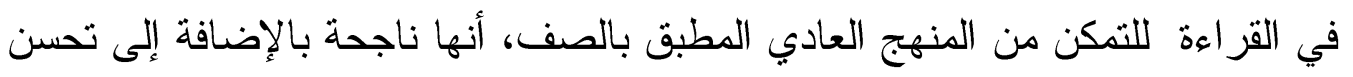

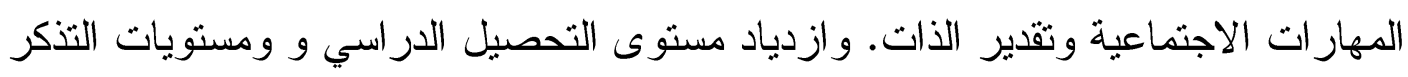

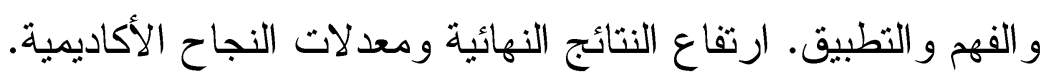

ع. أكدت الدر اسات التي طبقت إستر اتيجية خر ائط المفاهيم على التلاميذ الذين لديهم صعوبات

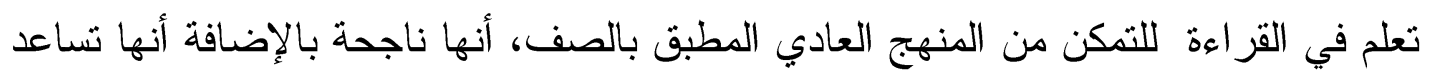




\section{مجلة الخدمة الاجتماعية}

المعلمين كذلك في التخطيط للاروس بتوضيحها للمفاهيم وتسهيل تسلسل التعلم لدى التلاميذ.

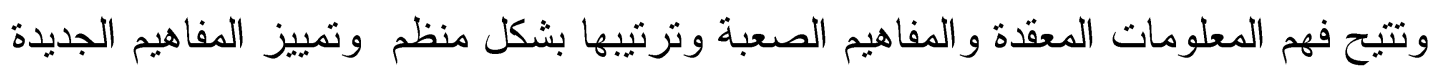

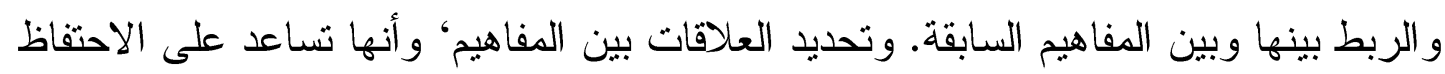

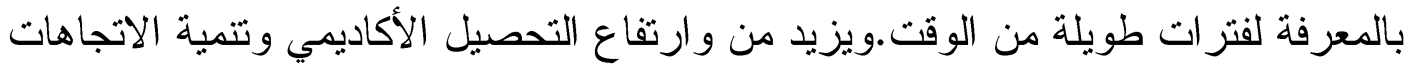
العلمية للتناميذ المتأخرين در اسيا.

ثالثاً: التوصيات:

من خلال ما طر ح أعلاه من استراتيجيات التدريس الثلاث المختلفة بداية من الإطار النظري

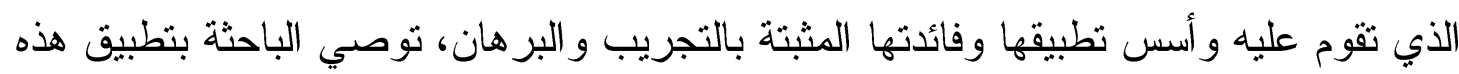

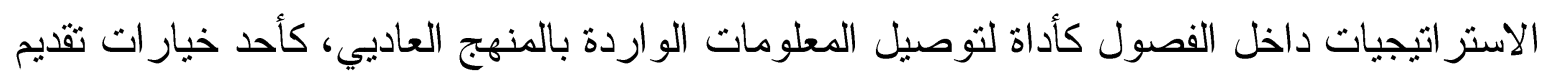
الخدمة للتلاميذ الذين لايهر صعوبات تعلم في فصول التعليم العام بمدراس المملكة العربية السعودية.

\section{رابعاً: مقترحات تر اها الباحثة لألة لاين}

ا ـ على الجامعات القيام بالبحوث و الدر اسات النوعية و التجريبية المحلية في الميدان، للتحقق من

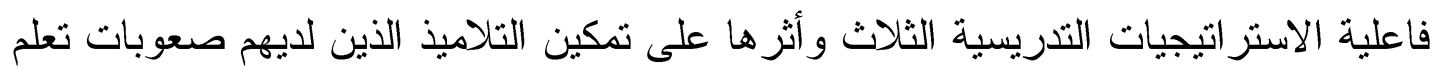

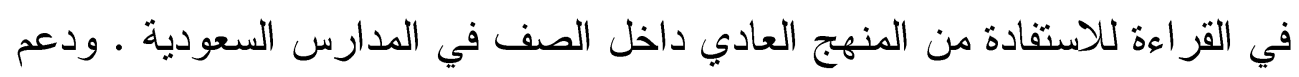
الدراسات و البحوث في هذا المجال لتفادي أي عقبات أو تحديات تو اجه ممارسته.

r. على وزارة التربية والتعليم أن تصمم المناهج الدراسية بطريقة تجبر المعلم أن ينفذ الدروس

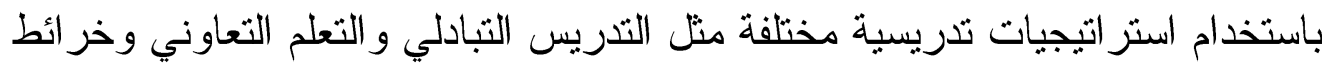
المفاهيم.

ץ. على الجامعات و الكليات أن تعنى بإعداد وتأهيل وتدريب وتخريج المعلمين الكفء القادرين

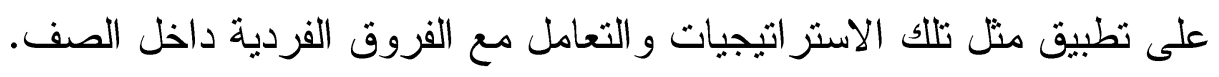

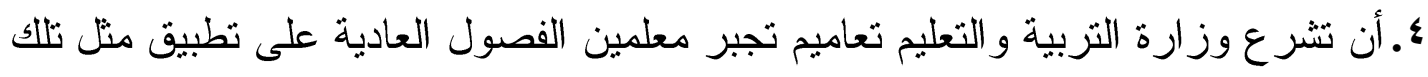

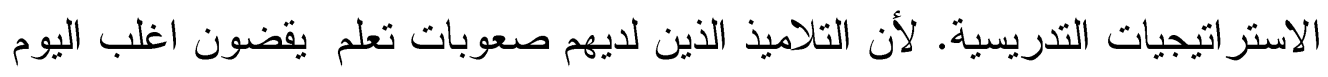

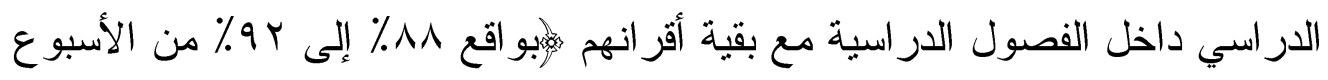

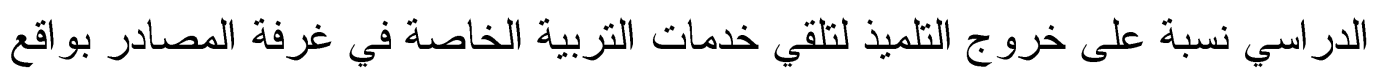




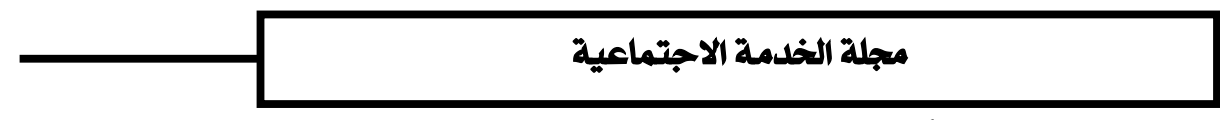

حصتان إلى ثلاث حصص أسبو عيا على المنصوص عليها في قرارات القو اعد التتظيميةهم

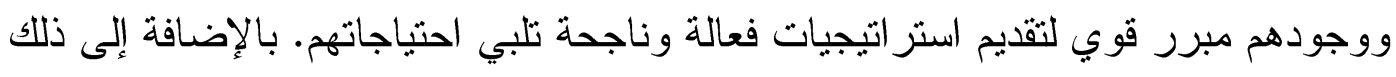

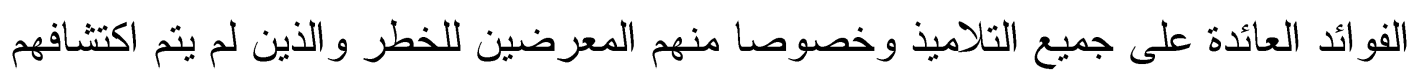
بعد للقصور الو اضح في أدوات التقييم والتثخيص المحلية المطبقة بالميدان المادية و البشرية.

ه. القيام بعمل دور ات تدريبية وتوعية المسبق للمعلمين القدامى وهمعلم التربية الخاصة، ومعلم

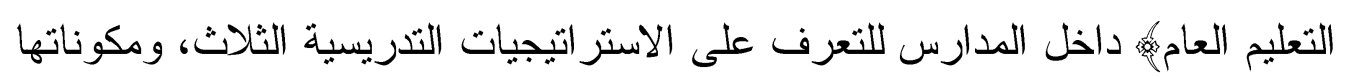

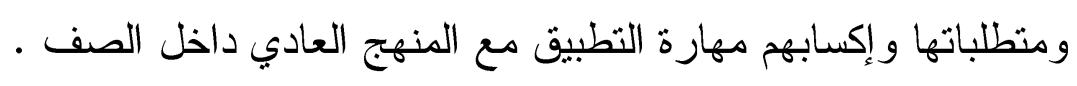
7.ويمكن اقتر اح إجراء عدد من الأبحاث و الدراسات المستقلية والتي تدور حول ما يلي:

أ- إجر اء در اسات حول فاعلية برنامج مقتر ح للمعلمات لاستخدام إستر اتيجيات التدريس الــثلاث

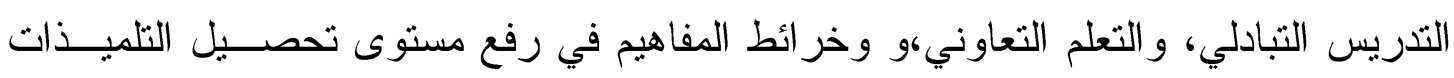
اللاتي لايهن صعوبات تعلم في القراعة.

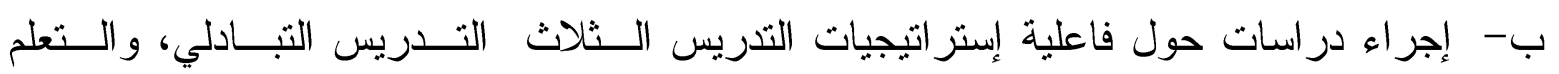

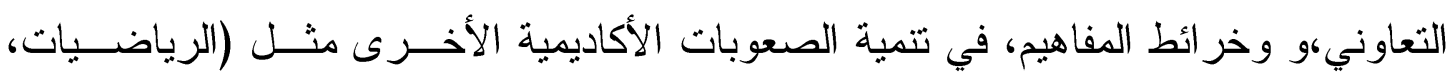
الإملاء، التعبير الكتابي).

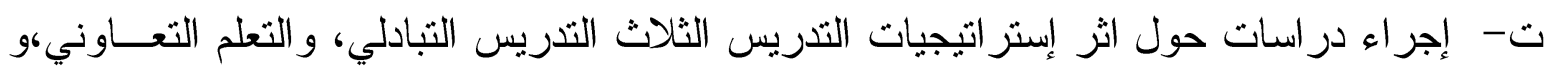

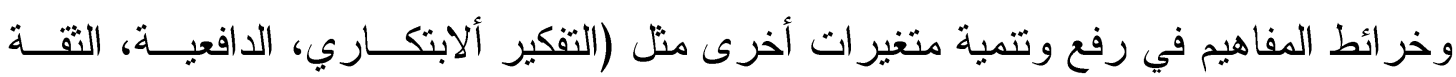

$$
\text { بالنفس). }
$$

ث- تحويل هذا البحث أو احد محاوره من دراسة نظرية إلى دراسة تجريبية ميدانية.

و أخير ال ايمكن الحصول على النتائج الايجابية لمثل نلك الاستر اتيجيات التدريسية مع التلاميذ

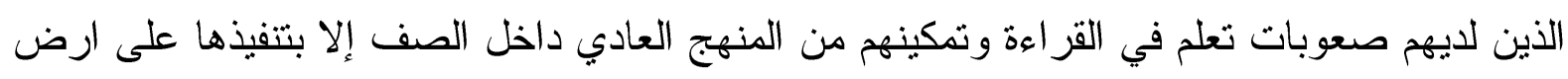

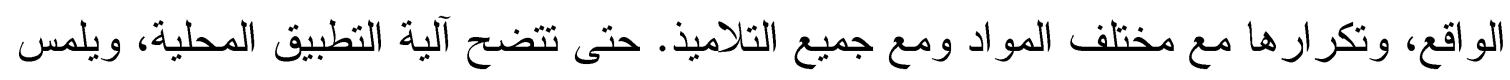

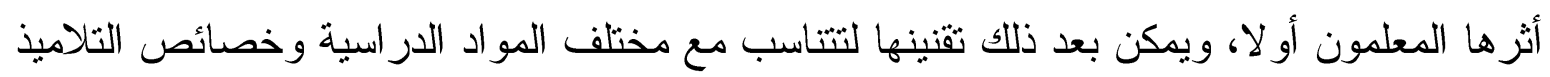

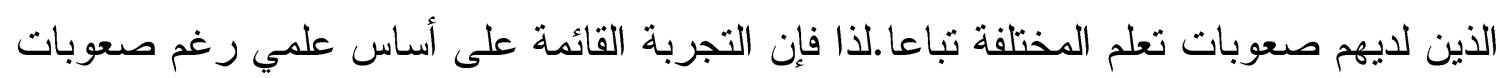
التطبيق بالميدان هي مفتاح البحوث المستقبلية. 


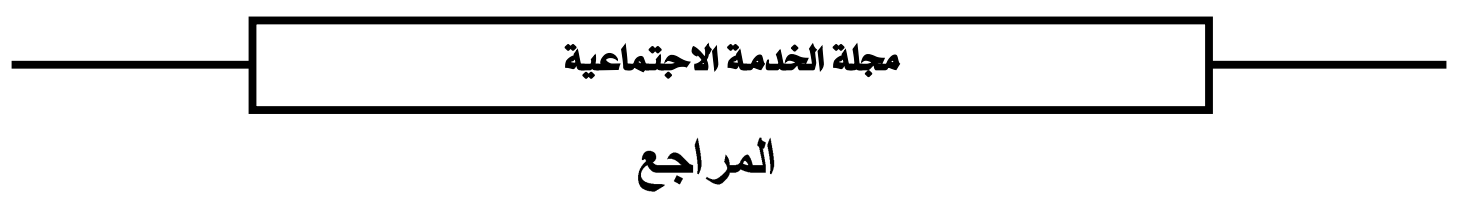

ابن منظور • (1911). لسان العرب. بيروت، لبنان: دار صادر.

أبو زينة، خطاب. ( س99 1). اثر التعلم التعاونسي على تحصيل الطلبة في الرياضيات واتجاهاتهر

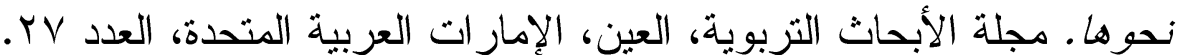

أبو نيان، إير اهيم. (1 . ب). صعويات التعلم طرق التدريس والاستر/تيجيات المعرفية. المملكة العربية السعودية، الرياض: أكاديمية التربية الخاصة.

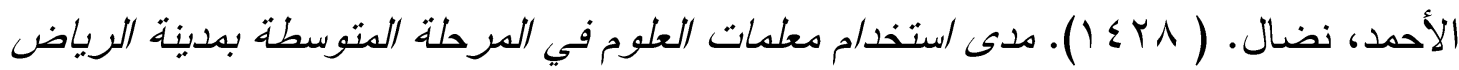
لاستر/تيجيات تنمبية مهارات وتفكبر المتعلدات من وجهة نظر المشرفات التربويات. مركز البحوث التزبوية، كلية التربية، جامعة الملك سعود.

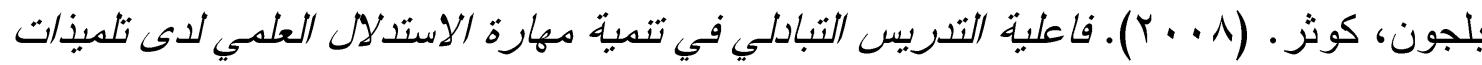

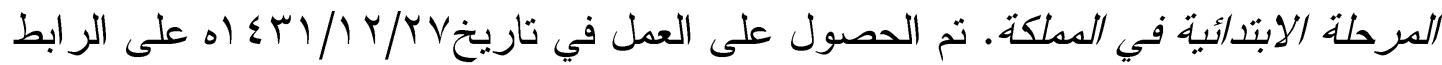
http://uqu.edu.sa/files2/tiny_mce/plugins/filemanager/files/4281116/tadrab.p

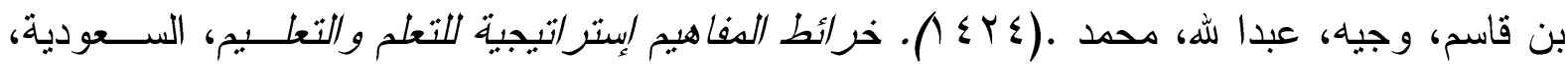

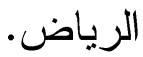

جمال، سليمان. (999 (1). فعالية إستر/تيجية الخريطة الدلالية في تنمية مهارات الفهم القرائي لدى

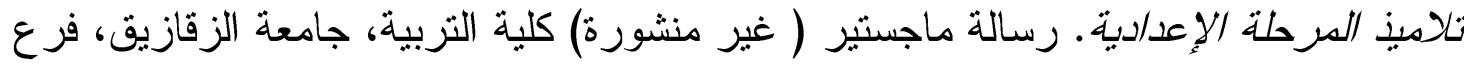




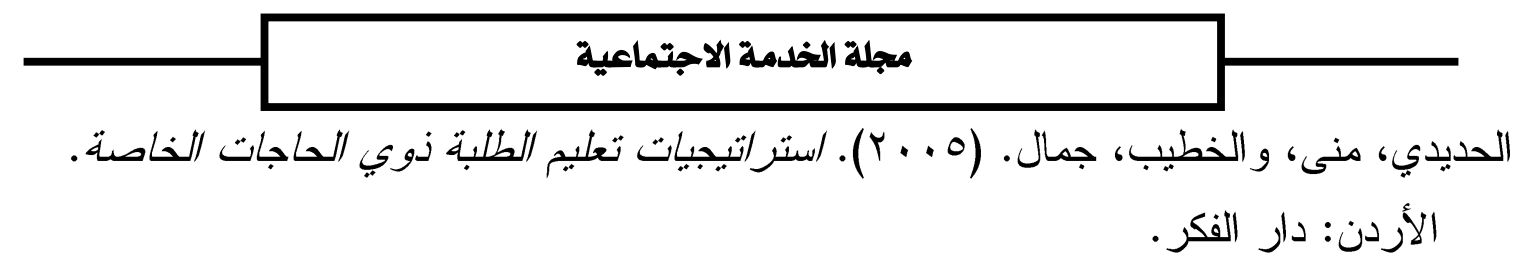

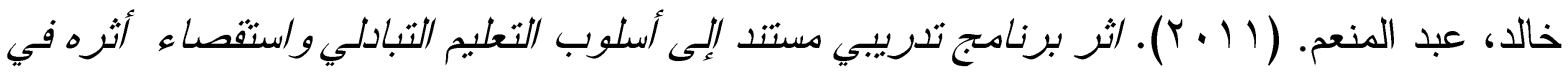

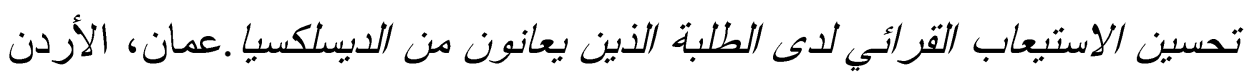
http://www.gulfkids.com/vb/showthread.php?t=7938

الخطيب، جمال و الحديدي، منى. (9 . ب؟). استراتيجيات تعليم الطلبة ذوي الحاجات الخاصة.

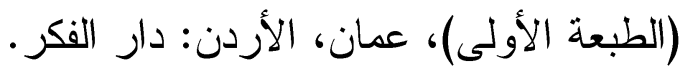

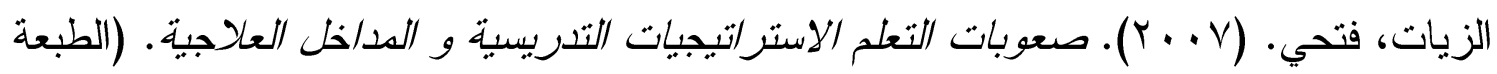

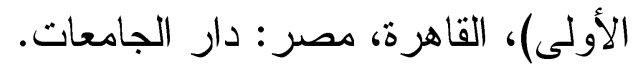

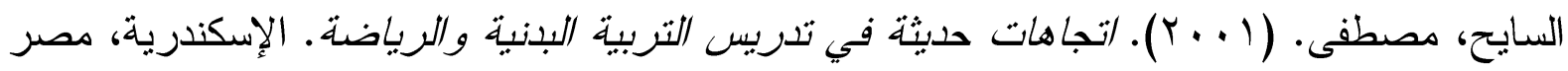

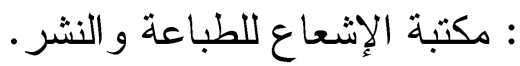

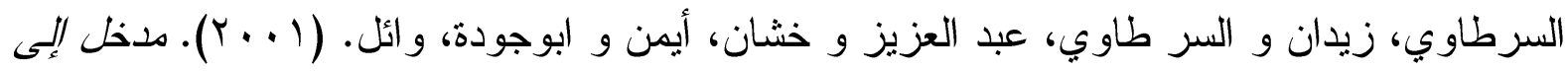

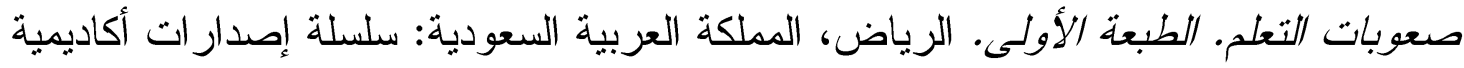

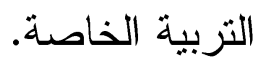

السرطاوي، زيدان ، و السرطاوي، عبدالعزيز ـ ( ـ99 1). صعوبات التعلم الأكاديمية والندائية.

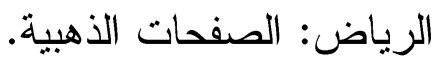

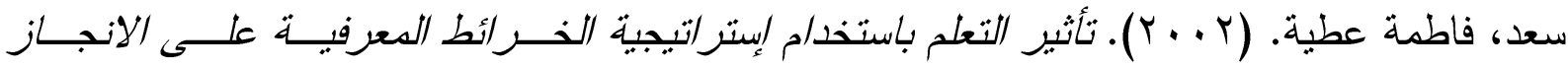

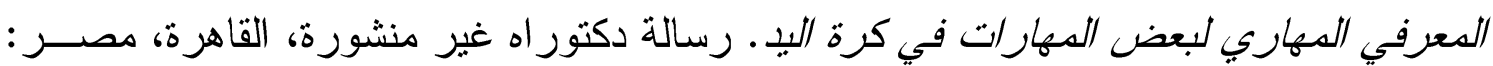
كلية التربية الرياضية للبنات بالجيزة. 


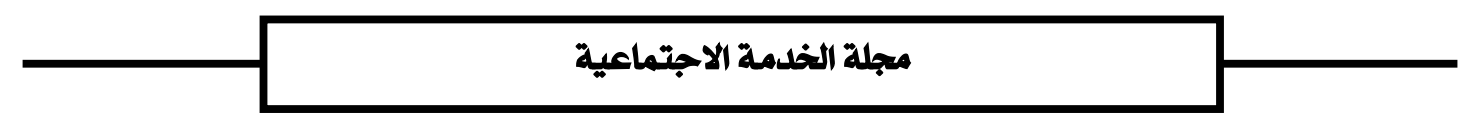

السليمان، مها. (T . . Y). اثر برنامج قائم على استخدام استر/تيجيات ما وراء المعرفة في تنمية مهارة

الفهم القرائي لدى تلمبذ/ت صعوبات القراعة في الصف السادس الابتدائسي. رســالة ماجسـتير،

البحرين: جامعة الخليج العربي.

$$
\begin{aligned}
& \text { السيد، أحمد البهي. (2009). اثر استخدم بعض استر/تيجيات التدريس العلاجية في تحسين } \\
& \text { مستوى الفهم القرائي لدى ذوي صعوبات القراعة من تلامبذ الصف الرابع الابتدائس. ثم }
\end{aligned}
$$

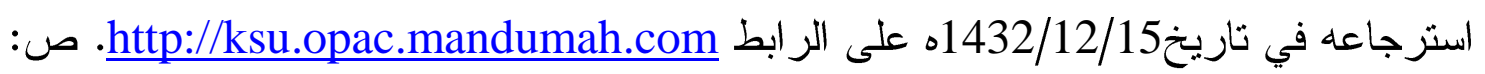

شرف الدين، سحر بس. (0 . ب). تأثبر التعلم التعاونس في درس التربية الرياضية على المهارات الاجتماعية وتقدير الذ/ت لتلميذات صعوبات التعلم. كلية التربية الرياضية للبنات بالقاهرة، جامعة

حلوان.

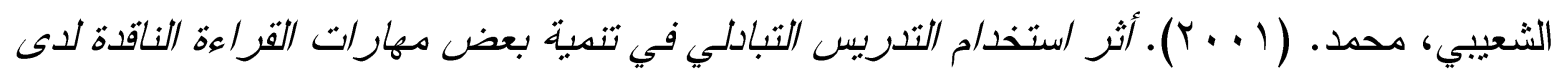
طلاب اللغة العربية بكلبة التربية بنزوى. عمان، مجلة البحث في التزبية و علم النفس، المجلد الخامس عشر، العدد الأول.

الصاوي، إسماعيل. (2009). صعوبات الفهم القرائي المعرفية والمبيا معرفية " مفاهيم نظرية، وتشخيص، وبرنامج مقترح". القاهرة، مصر : دار الفكر العربي. ص: 56.

صلاح، حسان. (9 . . ץ). من أسالبب التعلم النشط (التعلم التعاوني). تم الحصول على العمل في

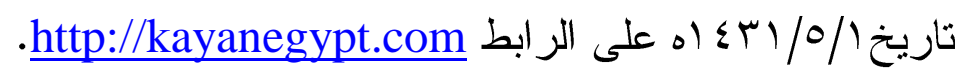

طالب، عبدا لله عبده أحمد. (ع . . Y). أثر استخدام إستر/تيجية خرائط الدفاهيم على تحصبل تلامبذ المرحلة الأساسية للعلوم وتنمية اتجاهاتهم نحوها. مجلة القراءة و المعرفة ، جامعة عين شمس ، كلية التربية ،العدد الخامس و التثلاثون ، يونيه. 


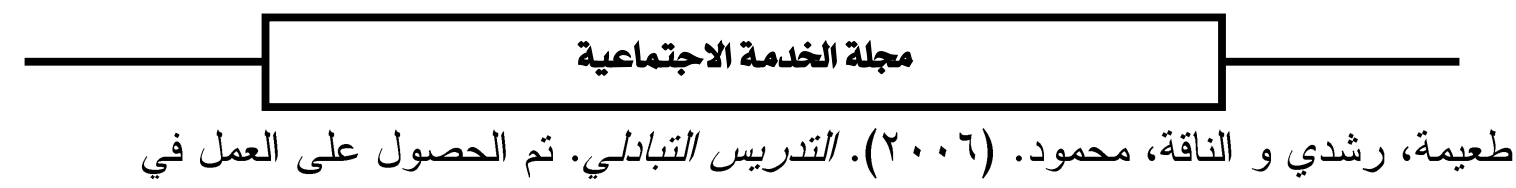

http://Www.gulfkids.com/vb/showthread.php?t=168 تاريخ / /

العارف، محمد. (1997). بعنوان اثر تدريس وحدة علاجبة مقترحة باستخدام خرائط

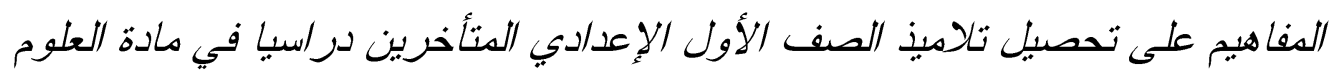

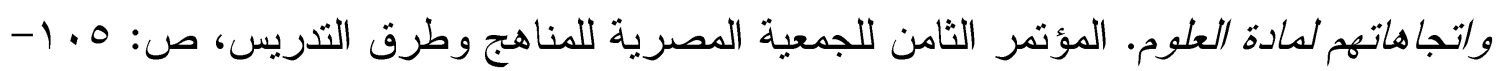

عبد الباري، ماهر • (• • ( ). استر/تيجيات فهم الدقروء أسسها النظرية و تطبيقاتها العهلية. (الطبعة

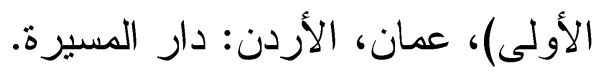

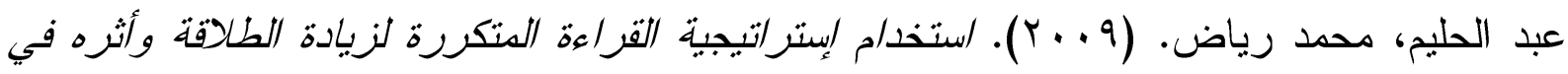

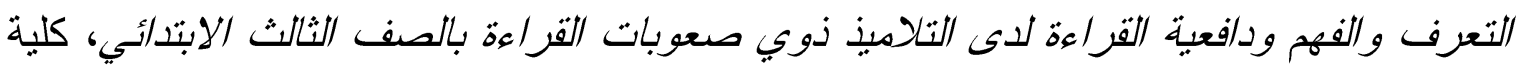

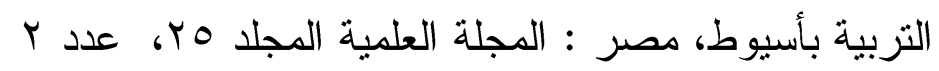

عبد السلام، عبد السلام مصطفى. (1 . . ب). الاتجاهات الحديثة في تدريس العلوم، القاهرة، مصر : دار الفكر العربي

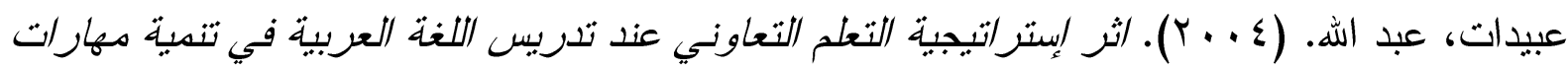

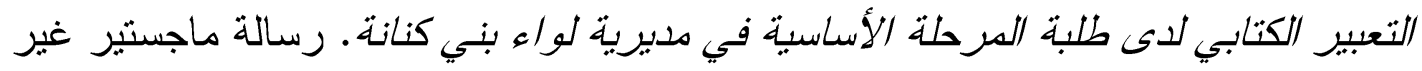
منشورة، جامعة عمان العربية، عمان، الأردن.

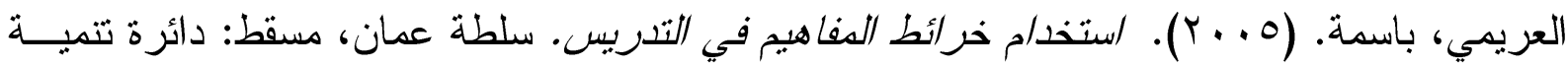
الموارد البشرية.

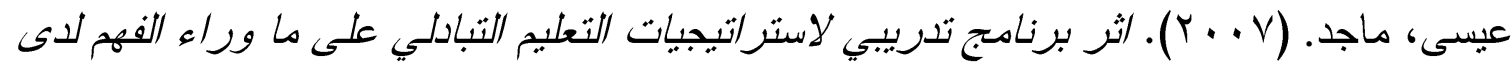

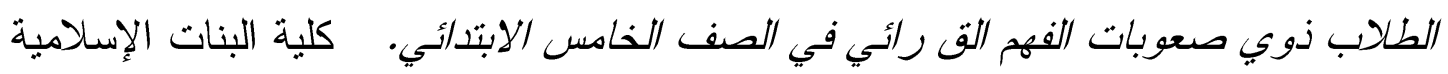

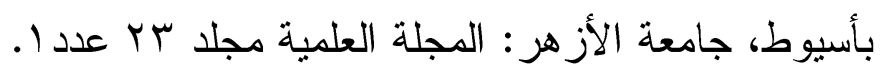




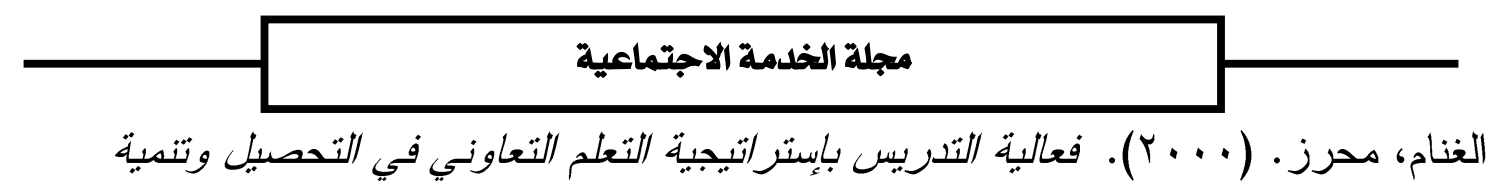

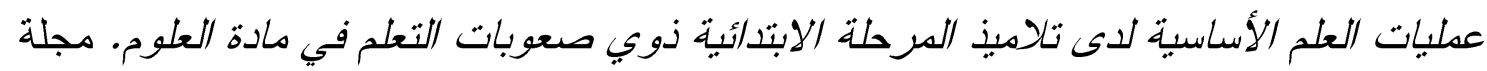

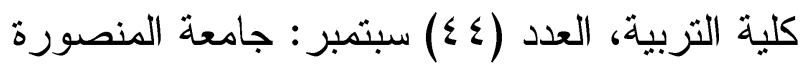

قرني، زبيدة. (991 1). فاعلبة استخدام إبتر/تيجبة خرائط الدفاهيم على كل من التحصيل واكتساب

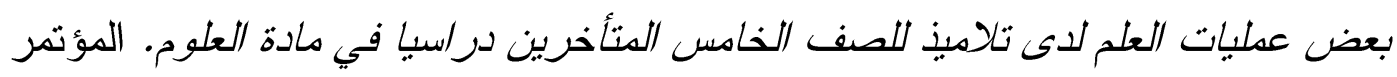

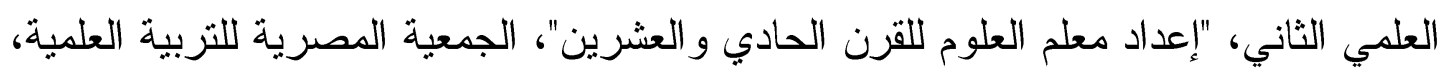

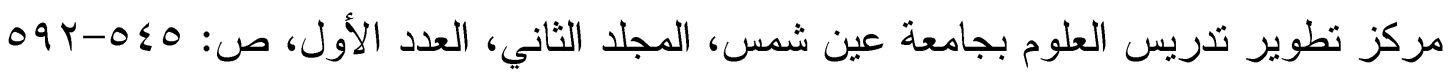
القيسي، بخيت. (1. (Y) اثر خرائط الدفاهيم في تحصيل طلبة المرحلة الأساسية وتفكيرهم النقاد

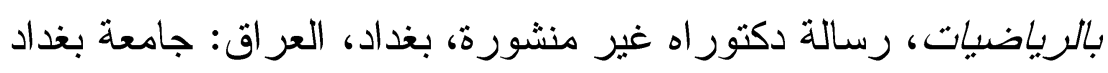

الكثيري، ر اشد، و النصار ، صالح.( . . ب). الدذخل البى التندريس. الرياض: مطابع الحميضي.

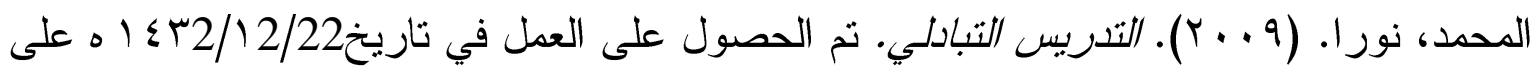
http://homeeconomics.mountada.biz/montada-f19/topic-t397.htm الر ابط

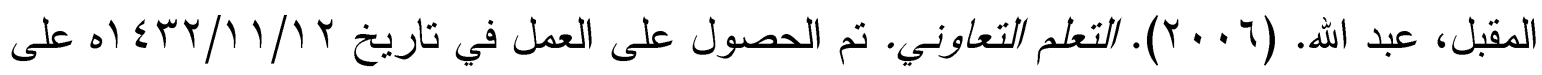
http://www.wpvschool.com الر ابط

ميرسر، سيسيل و ميرسر، أن ر. (1 . . ب). تدريس الطلبة ذوي مشكلات التعلم.الطبعة الأولى.

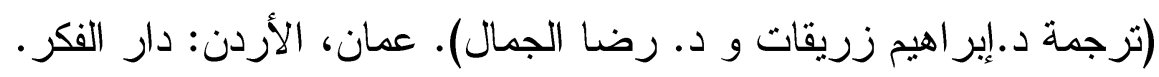

نوفلك، جوزيف ودين، بوب. (Y0 ( ). تعلم كبف تتعلم "مترجمة" ـ السعودية، الرياض : جامعة الملك

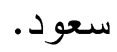

و اينبرنر ، سوزان. (Y . . r). تدريس الأطفال ذوي صعوبات التعلم في الصفوف العادية.

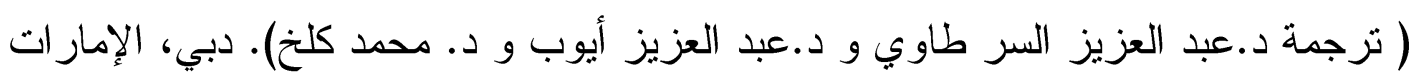
العربية المتحدة : دار القلم. 


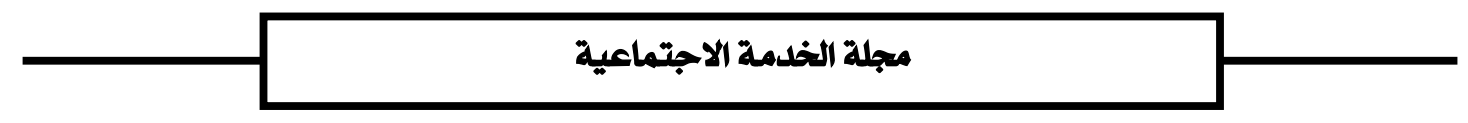

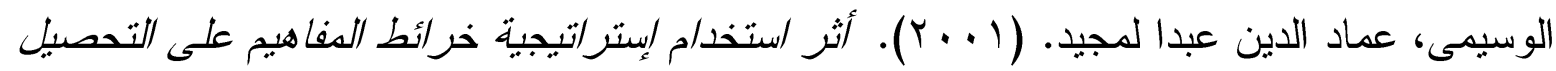

والاحتفاظ بالتعليم وتندية الاتجاه ندو مادة العلوم لدى تلاميذ المرحلة المتوسطة بالمدلكة العربية

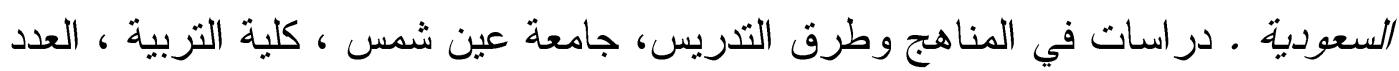

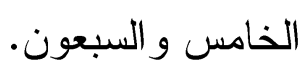

الو هر، محمود و أبو عجيمه، عصدت. (2004). فاعلية كل من الدقابلة العيادية وخرائط الدفا هيم فـي

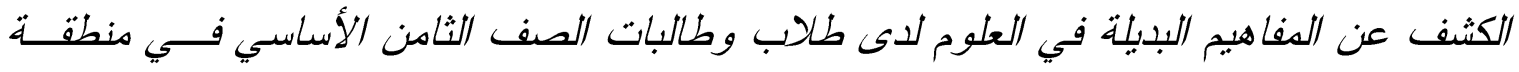

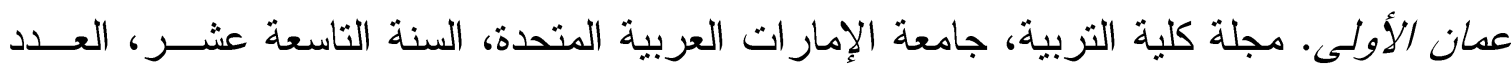

$. r)$

يحيى، حسن؛ و المنوفي، سعيد.( 1991) ـ العدخل إلى التندريس الفعـال. الريــاض: دار الصــولتية

للتزبية.

Armstrong, B, Johnson, D, and Balow B. (1986). Effects of Cooperative Vs Individualistic Learning Experiences on Interpersonal attractive between Learning Disabled and Normal. Progress elementary school students Contemporary Education Psychology, 6,102-109

Ashley ,K. (2008). The Effect of Focused Fluency Practice on Reading Rate Motivation and Interest in reading for struggling primary students . proceeding of the $4^{\text {th }}$ Annual GRASP symposium Wichita State University .

Bergerud, D , David, G and Ronald, A. (1988). The Effectiveness of Textbook adaptations in life science for High School Students with learning disabilities, Journal of learning disabilities . vol21, NO 2, PP 78-76

Clibmrn, j .and joseph, w. (1990). Concept maps to promote meaningful learning, journal of college science teaching vol no 4

Dembo, M. (1991). Applying educational psychology in the classroom, New York: Longman. 


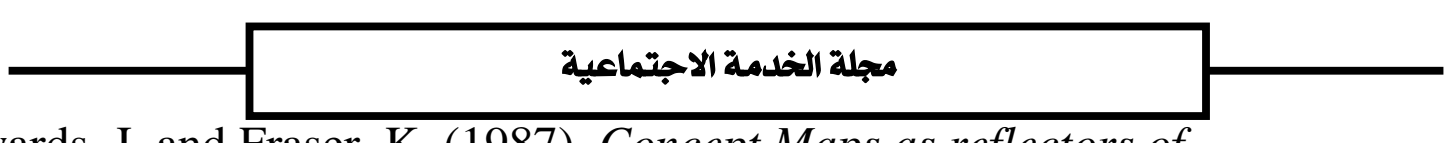

Edwards, J, and Fraser, K. (1987). Concept Maps as reflectors of conceptual understanding. Research in Science Education $13,19,26$

Eric, Lindstorm. (1997). Empower The Child with Learning Difficulties to Think Meat Cognitively, Australia, Journal of Remedial Education Vol.27 (5) PP415-426

Foil, Carolyn Rain water. (2001). Effects of two methods of vocabulary acquisition on students with mild learning disabilities, Dissertation Abstracts ( DAI - A 62_05, P 1792, )

Gillies ,R0byn. Ashman ,Adrian. (2000). The Effects of Cooperative Learning on Students with Learning Difficulties in the Lower Elementary School, Journal of Special Education, v34 n p19-27, ERIC Record Details - EJ606529

Jenkins, Antil, Wayne, and Vadasy. ( 2003). How Cooperative Learning Works for Special Education and Remedial Student, Exceptional children, Vol 69,No 3m2003, PP279,292

Kozulin, A. (1990). Vygotsky's Psychology, A Biography of Ideas. Cambridge, MA: Harvard University Press

Klingner, Janette \& Vaughn. Sharon . (1996). Reciprocal teaching of Reading Compre hension strategies for students with learning Disabilities who Use English as a Second Language, The elementary School Journal, Vol96, University of Chicago.

Palincsar, Annemarie \&Brown ,Ann. ( 1984). Reciprocal Teaching of Comprehension-Fostering and Comprehension- Monitoring Activities, Cognition and Instructions, Lawrence Erlbaum

Pratt, s ,Moesner, c, A Comparative. (1990). Study of Traditional and Cooperative Learning on Students Achievement, Research Report 143, Indiana

Putnam and others. (2005). Cooperative learning and peer acceptance of students with learning difficulties, Journal of learning disabilities. Vol 43 


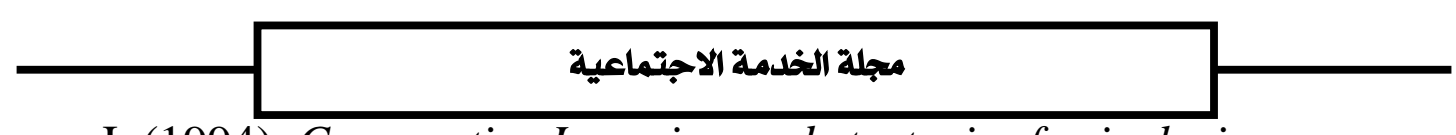

Putnam, J. (1994). Cooperative I earning and strategies for inclusion.

Baltimore: Paul H. Brookes

Ross, Terri Steidley. (2001 ). Learning with hearts and hands and voices:

Bringing Navajo wisdoun to the college classroom for students with learning disabilities Dissertation Abstracts ( DAI - A 62_04, P 1346)

Roundy, A. and Roundy, P. (2009).The Effect of Repeated Reading on students Fluency, Dose practice always make perfect? International Journal of Social Science 4(1), 54,59

Sizmur, and Osborne. (1997). Learning Processes and Collaborative Concept Mapping , International Journal of Science Education. Vol.19 No.10 P 1117-1135

Slavin, R. (1990). Synthesis of Research on Cooperative Learning Educational Leadership, American Educational Research Journal, Vol 71

Westberg, Suzanne L. (2001). Implementing Co-teaching as a model of inclusion of students with mild learning disabilities in general education class rooms, Dissertation Abstracts (DAI - A 62_03, P 977) 